\title{
WestVirginiaUniversity
}

THE RESEARCH REPOSITORY @ WVU

Graduate Theses, Dissertations, and Problem Reports

2010

\section{The alto trombone as a transposing instrument}

Brian Kirke Plitnik

West Virginia University

Follow this and additional works at: https://researchrepository.wvu.edu/etd

\section{Recommended Citation}

Plitnik, Brian Kirke, "The alto trombone as a transposing instrument" (2010). Graduate Theses,

Dissertations, and Problem Reports. 2956.

https://researchrepository.wvu.edu/etd/2956

This Dissertation is protected by copyright and/or related rights. It has been brought to you by the The Research Repository @ WVU with permission from the rights-holder(s). You are free to use this Dissertation in any way that is permitted by the copyright and related rights legislation that applies to your use. For other uses you must obtain permission from the rights-holder(s) directly, unless additional rights are indicated by a Creative Commons license in the record and/ or on the work itself. This Dissertation has been accepted for inclusion in WVU Graduate Theses, Dissertations, and Problem Reports collection by an authorized administrator of The Research Repository @ WVU.

For more information, please contact researchrepository@mail.wvu.edu. 
The Alto Trombone as a Transposing Instrument

Brian Kirke Plitnik

Research Project submitted to the

College of Creative Arts

at West Virginia University

in partial fulfillment of the requirements

for the degree of

Doctor of Musical Arts

in

Trombone Performance

H. Keith Jackson, D.M.A., Chair

Virginia Thompson, D.M.A.

Paul Scea, M.M.

C.B. Wilson, Ph.D.

Dianne Trumbull, M.D.

Division of Music

Morgantown, West Virginia

2010

Copyright 2010 Brian Kirke Plitnik 


\section{ABSTRACT \\ The Alto Trombone as a Transposing Instrument}

\section{Brian Kirke Plitnik}

Coinciding with a concern for authenticity and balance in the orchestral brass section, and a renewed interest in $18^{\text {th }}$ century solo trombone literature, the nearly forgotten alto trombone has enjoyed a rousing comeback in recent decades. The alto trombone has traditionally existed as a concert-pitch instrument likely due to its early use in church music as a means of doubling the voice. Standard notational practice for the modern E-Flat alto has changed little over the centuries. While performance practice in previous centuries is not verifiable, current alto trombonists are tenor trombonists first; the alto trombone is nearly always a secondary instrument. Trombonists typically make the transition from a tenor trombone pitched in B-Flat to an alto trombone pitched in E-Flat without the use of a notational transposition. This is contrary to the overwhelming trend for wind instruments. Generally, secondary wind instruments pitched in different keys are written at a transposition for (relative) ease of maneuvering between the primary and secondary instruments. With transposition, the same basic fingering/slide patterns from primary to secondary instrument are maintained.

Despite the success of the transposing method with other instruments, the most accepted method for alto trombone performance and pedagogy is for the alto to be played as a non-transposing instrument in alto clef. This requires the tenor trombonist learning to play alto to: 1 ) have a command of alto clef-a clef that is infrequently used for tenor trombone outside of a small body of the orchestral literature, 2) relearn all the correct positions for written notes, 3) relearn the appropriate notes for use of alternate positions, and 4) recognize the inherent intonation tendencies of a harmonic series constructed on E-Flat instead of BFlat-all of this in addition to the other inevitable physical adjustments of switching between trombones in terms of proper tone production, range, and slide maneuverability. Considering these obstacles, it is hardly surprising that alto trombone playing is usually reserved for advanced college study, or graduate work.

Due to the secondary status of the alto trombone, transposition allows the alto trombonist to maintain familiar tenor slide positions and intonation tendencies. This provides an advantage that outweighs the benefit of merely having an instrument that sounds at concert pitch. In an age of notation software, scanners, and music translation programs, the burden of rewriting music is no longer a valid basis to preclude the advantages of the transposing method of alto trombone. After reexamining the factors surrounding the existence of the alto trombone as a nontransposing instrument, the current study proposes that a change in the fundamental pedagogy of this instrument is warranted. 


\section{TABLE OF CONTENTS}

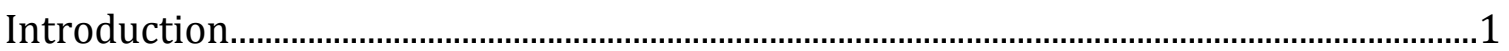

I. Brief History of Alto Trombone Notation.........................................................................

A. Origins of Alto Trombone Notation...................................................................10

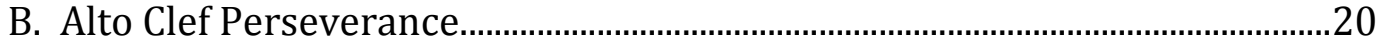

C. Horns, Trumpets, and Transposition....................................................................23

D. Trombone Notation at the Dawn of Romanticism.............................................26

E. Equivocal Notation: Alto or Tenor Trombone?.................................................31

II. Alto Trombone Pedagogy ……………………….............................................................39

A. Categories of Method Books................................................................................42

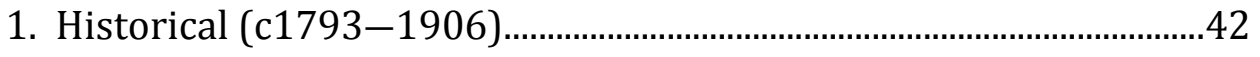

2. Current (1950 to present).........................................................................44

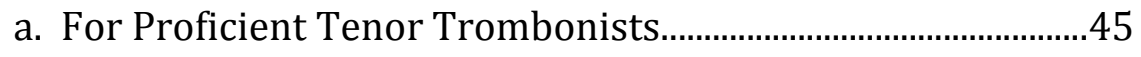

b. For Young Beginners......................................................................... 46



B. Objective Descriptions of Unreviewed Alto Trombone Method Books.......51

C. The Transposing Method............................................................................................58

III. Evaluating the Transposing Method...............................................................................63

A. Historical Precedent of Trombone Transposition.............................................65

B. Printed Commentary and Assessment......................................................................76

1. General Alto Trombone References.............................................................76

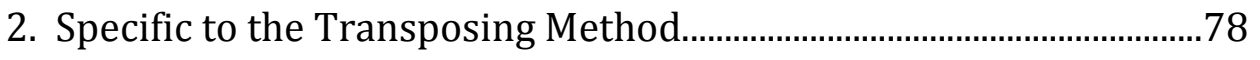

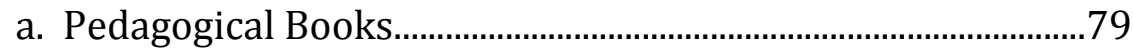

b. Periodical Articles................................................................................

c. Dissertations.........................................................................................

Conclusions. 
Appendix A.

Classification of Specific Pitch Indications (ITA Convention)

Appendix B.

List of Symphonic and Operatic Orchestral Works with Trombone Parts for which

the Alto Trombone is Appropriate.

Appendix C.

Solo Literature Written for Alto Trombone Currently Available with Transposed

Bass Clef Parts.

Appendix D.

List of Reviews of Alto Trombone Pedagogical Materials as Published in the

International Trombone Association Journal.

Appendix E.

A Few Common Orchestral Alto Trombone Parts Rewritten in Transposed Bass

Clef.

Bibliography.

128 


\section{List of Tables and Musical Examples}

Table 1.

Orchestral Notational Variations that include Alto Trombone and/or Alto Clef..........38

Table 2.

Categorization of Alto Trombone Method Books

50

Table 3.

Quick Reference for Reviews of Alto Trombone Pedagogical Materials.

Example 1-Clef Varieties

Example 2-Pedal Notes in Bass Clef versus Tenor Clef. 30

Example 3-Nøkleby's Use of Transposition

Example 4-Berlioz's Illustration of Transposition for the Valved Alto Trombone...66

Example 5-Method of Transposition for the Db Alto Trombone 70

Example 6-Clef Visualization for Bb Treble Clef Parts 72

Example 7-A Notational Comparison of Tenor Clef, and Treble Clef in Bb and Eb...73

Example 8-The Note "d" in Concert-Pitch Alto Clef for 3 Different Trombones........75

Example 9-The Note "d" with Transpositions for 2 Varieties of Alto Trombone......75 


\section{INTRODUCTION}

Coinciding with a concern for authenticity and balance in the orchestral brass section, and a renewed interest in $18^{\text {th }}$ century solo trombone literature, the nearly forgotten alto trombone has enjoyed a rousing comeback in recent decades. ${ }^{1}$ The alto trombone has traditionally existed as a concert-pitch instrument likely due to its early use in church music as a means of doubling the voice. Standard notational practice for the alto trombone has changed little over the centuries. The modern alto, pitched in Eb, plays written notes at concert-pitch the same as the tenor trombone pitched in $\mathrm{Bb}$. (The transposing tenor trombone in the present British brass band tradition-in which the tenor trombone does transpose true to its fundamental pitch of $\mathrm{Bb}$ but in a different octave-is a sole exception). ${ }^{2}$

While performance practice in previous centuries is not verifiable, current alto trombonists are tenor trombonists first; the alto trombone is nearly always a secondary instrument. ${ }^{3}$ For a trombonist to make the transition from a tenor trombone pitched in $\mathrm{Bb}$ to an alto trombone pitched in $\mathrm{Eb}$ without the use of a notational transposition is contrary to the overwhelming trend for wind instruments. Generally, secondary wind instruments pitched in different keys are written at a transposition for (relative) ease of maneuvering between the primary and secondary instruments. ${ }^{4}$ Consider, for example, the alto flute-sounding a perfect fourth lower than written, or the alto (Eb) clarinet-sounding a perfect fifth lower than that same note written for the standard clarinet in Bb. ${ }^{5}$ These

\footnotetext{
${ }^{1}$ Will Kimball provides a concise historical explanation of the alto's comeback in his article, "The Rise and Fall...and Rise of the Alto Trombone." NACWPI Journal-Official Publication of the National Association of College Wind and Percussion Instructors 48 (Spring 2000): pp. 23-28.

2 Anthony Baines, and Arnold Myers, "Trombone, §1: Slide trombone." Grove Music Online, ed. Deane Root. Oxford University Press, 2007-2010. Available at <http://www.oxfordmusiconline. com>, accessed October 23, 2009.

3 Benny Sluchin, Study Material for the Alto Trombone, vol. 1 (Warwick, England: Warwick Music, 2000), p. 18.

${ }^{4}$ Ibid.

${ }^{5}$ Kent Kennan and Donald Grantham, The Technique of Orchestration (Upper Saddle River, NJ: Prentice Hall, 1997), pp. 384-387.
} 
instruments, as well as virtually every other aerophone, transpose to change the sounding pitch of the instrument but not the written pitch. In this way, the same basic fingering patterns from primary to secondary instrument are maintained.

Despite the success of the transposing method with other instruments, the most accepted method for alto trombone performance and pedagogy remains centuries old; the alto is traditionally played as a non-transposing instrument in alto clef. This requires the tenor trombonist learning to play alto to: 1) have a command of alto clef-a clef that is infrequently used for tenor trombone apart from a small body of the orchestral literature, ${ }^{6}$ 2) relearn all the correct positions for written notes, 3) relearn the appropriate notes for use of alternate positions, and 4) recognize the inherent intonation tendencies of a harmonic series constructed on $\mathrm{Eb}$ instead of $\mathrm{Bb}$-all of this in addition to the other inevitable physical adjustments of switching between trombones in terms of proper tone production, range, and slide maneuverability. ${ }^{7}$ Considering these obstacles, it is hardly surprising that alto trombone playing is usually reserved for advanced college study, or graduate work. ${ }^{8}$

Due to the secondary status of the alto trombone, and the accomplished system of notational transposition that the majority of other aerophones employ for secondary instruments, it seems only logical that transposing the music to allow the alto trombonist to maintain familiar tenor slide positions and intonation tendencies is an advantage that outweighs the benefit of merely having an instrument that sounds at concert pitch. Two of the most commonly used pedagogical texts for alto trombone ${ }^{9}$ serve to corroborate this. Stephen Anderson's A Complete Method for Eb

\footnotetext{
${ }^{6}$ Gardner Read, Music Notation: A Manual of Modern Practice, $2^{\text {nd }}$ ed. (Boston: Allyn and Bacon, Inc., 1969), p. 355.

7 Donald Appert, “The Alto Trombone: Its Uses, Problems and Solutions." ITA Journal 8 (March 1980): p. 13.

${ }^{8}$ Douglas Warner found that the majority of trombonists who study alto begin the alto instrument in graduate school or after formal education in Current Trends in Alto Trombone Pedagogy in the United States (DMA Document, University of Cincinnati, College-Conservatory of Music, 2005), p. 85.

9 The Anderson and Sluchin method books were determined to be "most commonly used" by Warner's Current Trends in Alto Trombone Pedagogy in the United States, pp. 85-86.
} 
Alto Trombone, ${ }^{10}$ and Benny Sluchin's Study Material for Alto Trombone ${ }^{11}$ both list the foremost disadvantage to learning and teaching the alto trombone as a transposing instrument as stemming from the simple fact that the majority of published literature is not written this way. The current study proposes that in an age of notation software, scanners, and music translation programs, the burden of rewriting music is no longer a valid basis to preclude the advantages of the transposing method of alto trombone.

The purpose of this study is:

To reexamine the factors surrounding the existence of the alto trombone as a nontransposing instrument and determine if a change in the fundamental pedagogy of this instrument is warranted.

\footnotetext{
${ }^{10}$ Stephen Anderson, A Complete Method for Eb Alto Trombone, 2 vols. (Denton, TX: Modern Editions, 1984-1986).

${ }^{11}$ Benny Sluchin, Study Material for Alto Trombone, 4 vols. (Warwick, England: Warwick Music, 2000-2003).
} 


\section{CHAPTER I \\ BRIEF HISTORY OF ALTO TROMBONE NOTATION}

A comprehensive evaluation of the fundamentals of alto trombone pedagogy necessitates an historical review of both the alto trombone as an instrument, and of the alto trombone's notational tradition. A number of previous studies have adequately discussed the history of the alto trombone as an instrument. Doctoral research projects by David Mathie ${ }^{12}$, and Mark Hartman ${ }^{13}$ include concise historical overviews of the alto trombone, and Wayne Wells ${ }^{14}$ provides a more detailed account of trombone history in Austria, a geographical region where alto trombone was at one time most prevalent. Alto trombone history is also outlined in several periodical articles, most notably by Stephen Anderson, ${ }^{15}$ and Will Kimball, ${ }^{16}$ and considerable coverage can be found online in articles by Ken Shifrin, ${ }^{17}$ Rob Slocombe, ${ }^{18}$ and Will Kimball. ${ }^{19}$

An historical discussion of notation for alto trombone is far less comprehensive. In fact, the notation of music for trombone is often given little focus in research concerning trombone history. This solitary sentence from the entry for

\footnotetext{
${ }^{12}$ David Mathie, The Alto Trombone: Twentieth-Century Performance Practices and Pedagogy in the United States (DMA Document, University of Georgia, 1993).

${ }^{13}$ Mark Hartman, The Use of the Alto Trombone in Symphonic and Operatic Orchestral Literature (DMA Research Paper, Arizona State University, 1985).

${ }^{14}$ Wayne Wells, Music for the Trombone and Voice from the Hapsburg Empire: An Historical Overview with Tenor Trombone Transcriptions (DMA Dissertation, University of Maryland, 2005).

${ }^{15}$ Stephen C Anderson, "The Alto Trombone, Then and Now." The Instrumentalist 40 (November 1985): pp. 54-62.

${ }^{16}$ Will Kimball, "The Rise and Fall...and Rise of the Alto Trombone." NACWPI Journal-Official Publication of the National Association of College Wind and Percussion Instructors 48 (Spring 2000): pp. 23-28.

17 Ken Shifrin, "The Alto Trombone in the Orchestra 1800-2000." British Trombone Society [online], 2008. Extracted from PhD Thesis, Oxford University, 2000. Available at <http://www. britishtrombonesociety. org/resources/shifrin/the-alto-trombone-in-the-orchestra-18002000.html>, accessed January 8, 2010.

${ }^{18}$ Rob Slocombe, "Fall and Rise of the Alto Trombone: 1830-2000." British Trombone Society [online], 2008. Available at <http://www.britishtrombonesociety.org/resources/currentarticles/falland-rise-of-the-alto-trombone-1830-2000.html >, accessed January 8, 2010.

${ }^{19}$ Will Kimball, "Alto Trombone Timeline." Will Kimball, Trombone [online].
} 
"trombone" in The Grove Dictionary of Music and Musicians is representative of the minimal and matter-of-fact attention that the topic of trombone notation receives:

The trombone is a non-transposing instrument except for tenor trombones in the British-style brass band, where the parts are written in the treble clef a major ninth higher than they sound. ${ }^{20}$

Similarly, standard texts on orchestration offer descriptions of modern trombone notation without much elaboration on the historical points of why some instruments use transposition and others do not. The following statements represent the entire commentary (per respective source) afforded to trombone notation as found in several well-known orchestration manuals. Italics have been added to segments specifically focused on transposition:

\section{The Technique of Orchestration by Kent Kennan and Donald Grantham:}

As a rule, instruments pitched in keys other than $C$ are transposing instruments. Not so with the tenor trombone. Although built basically around the harmonic series of Bb, it sounds as written. It may be notated in either bass or tenor clef, the latter being commonly chosen for higher passages in order to avoid the use of too many ledger lines... The alto clef, found in some older scores, is almost never employed for the trombone nowadays. It is a holdover from the period when the alto trombone was in common use. ${ }^{21}$

\section{Instrumentation by Ebenezer Prout:}

Unlike the horns and trumpets, the trombones are non-transposing instruments, the notes being always written in their actual pitch. With regard to their notation, several systems are adopted by different composers. Some always write the three parts on one line, using either the tenor or the bass clef indifferently, according to the position of the chords, choosing that which requires the fewest ledger lines; others, again, write the alto and tenor on one stave, using the $\mathrm{C}$ clef either on the third or fourth line, and giving the bass trombone a line to itself with the F clef;

\footnotetext{
${ }^{20}$ Baines and Myers, "Trombone, $\S 1$ : Slide trombone." Grove Music Online.

${ }^{21}$ Kennan and Grantham, The Technique of Orchestration, p. 147.
} 
while many give a separate line to each instrument, and write each with its proper clef. $^{22}$

\section{Orchestration by Cecil Forsyth:}

Before the Alto-Trombone became obsolete it was customary either (1) to use three staves for the Trombones with the three clefs alto, tenor, and bass; or (2) to write the first two Trombone parts on one stave with the alto- or tenor-clef, while the Bass-Trombone had a separate bass-clef stave; or (3) to write all three instruments on one line, generally with the bass-clef but occasionally with the tenor-clef. Nowadays the usual plan is to write the two first Trombone parts on one stave. The tenor- or bass-clef is used at convenience. The Bass-Trombone then shares a bass-clef stave with the Tuba. The Tenor-Trombone is the first instrument under our notice which, built in a key other than $C$, is yet not treated as a transposinginstrument. Crooks, though tried on the Trombones, have never "made good" with them ... Like all the other Trombones, [the Alto] was written for as a non-transposing instrument. The part was almost invariably written in the alto-clef, but the bass-clef was used occasionally and conveniently for the lowest notes. ${ }^{23}$

\section{Orchestration by Walter Piston:}

Music for the trombone is written in bass and tenor clefs, the tenor clef to save ledger lines in the high register. The trombone has always been a nontransposing instrument, the notes sounding as written ... The alto trombone is pitched a perfect fourth above the tenor, so its fundamental in closed position is Eb ...Parts for it were written ordinarily in the alto clef, and this is probably one reason for the use of the alto clef for the first and second trombones, seen in some scores even when no alto trombone is intended. ${ }^{24}$

\section{The Study of Orchestration by Samuel Adler:}

Although three types of trombones are still in general use today-the alto, tenor, and

\footnotetext{
22 Ebenezer Prout, Instrumentation [1879](Reprint, St. Clair Shores, MI: Scholarly Press, 1970),p. 89. Prout goes on to include a notated example that presumes the alto clef to be the "proper" clef for the first trombone part.

${ }^{23}$ Cecil Forsyth, Orchestration [1914] (Reprint, New York: Dover Publications, 1982), pp. 138-139.

${ }^{24}$ Walter Piston, Orchestration (New York: W. W. Norton \& Company, Inc., 1955), pp. 268-270.
} 
bass trombone-there are no great problems of instrument use and transposition to frustrate the composer or orchestrator. It is worth noting, however, that the British brass band, which is very much alive in our time, uses all kinds of transpositions for the trombone and for the tuba which are rarely found in our modern symphony orchestras...Trombones have always been nontransposing instruments. The tenor and bass trombones are notated in the bass clef up to the $\mathrm{G}$ above middle $\mathrm{C}$; then, to save ledger lines, the tenor clef is used. The alto trombone parts have traditionally been notated in the alto clef. ${ }^{25}$

The above texts provide adequate summary of contemporary orchestration guidelines, and historical background to scoring for trombone section. However, the underlying basis for the current notational standard of concert-pitch for alto trombone-a notational practice that is contrary to nearly all other secondary wind instruments-constitutes a subject otherwise ignored. Consider, for example, Alfred Blatter's acumen regarding the general use of transposition:

Usually an instrument is written as a transposing instrument so that a performer may transfer eye-and-hand coordination skills learned on one family member to another family member. ${ }^{26}$

This insight is not reiterated, nor its curious lack of application remarked upon, during Blatter's commentary on the alto member of the trombone family. Blatter instead presents the standard report on trombone notation excepting his disregard for the present-day British use of transposing treble clef notation for tenor trombone; he inaccurately refers to this type of transposition as "obsolete."

\section{Instrumentation/Orchestration by Alfred Blatter:}

The trombones are all written at concert pitch ...In the nineteenth century orchestra, a familiar trombone section consisted of an alto, a tenor, and a bass trombone, scored in the alto, tenor, and bass clefs, respectively...Current practice is

\footnotetext{
${ }^{25}$ Samuel Adler, The Study of Orchestration, $2^{\text {nd }}$ ed. (New York: W. W. Norton \& Company, Inc., 1989), p. 312.

${ }^{26}$ Alfred Blatter, Instrumentation/Orchestration, 2 ${ }^{\text {nd }}$ ed. (New York: Schirmer Books, 1985), p. 10.
} 
to use tenor and bass clef for all trombone parts, the only exceptions being that bass clef only is used in music for elementary or high school bands or orchestras and for jazz bands. In professional writing the alto clef may be used for very high passages or when an alto trombone is specified. Two types of treble clef notation are sometimes found. One type merely uses treble clef for pitches too high for tenor clef; it is a non-transposing notation. Another type of notation, which is now obsolete, treats the tenor trombone as a transposing Bb instrument, written a major ninth above sounding pitch in the treble clef. This notation was used by converted cornet or trumpet players playing valve trombones. ${ }^{27}$

Nonetheless, if the topic of trombone notational history is given only sparse coverage in orchestration manuals, it is all but abandoned in other trombone history resources. The standard authoritative texts on the trombone as an instrument (most notably by Robin Gregory, ${ }^{28}$ Trevor Herbert, ${ }^{29}$ and Philip Bate ${ }^{30}$ ) that present in minute detail a thorough and painstakingly researched account of trombone history on an expansive range of subjects, all fail to engage or evaluate the current system of trombone notation. Why then has the topic of notation for trombone been neglected? Has this angle of research been rendered irrelevant due to a compulsive devotion to our inherited orchestration practice and trombone notation status quo?

The brevity of discourse concerning trombone notation is undoubtedly due in part to the assumption that the tradition of trombone notation is self-explanatory and practical. A review of trombone history yields that the pairing of alto clef and alto trombone was logical for the time-period in which this system emerged. The tradition of writing trombone parts to correspond with vocal ranges and clefs stems from the mid-Renaissance, a time when the trombone was commonly used as an

\footnotetext{
27 Blatter, Instrumentation/Orchestration, pp. 160-162.

28 Robin Gregory, The Trombone: The Instrument and its Music (New York and Washington: Praeger Publishers, 1973).

${ }^{29}$ Trevor Herbert, The Trombone (New Haven and London: Yale University Press, 2006).

30 Philip Bate, The Trumpet and Trombone: An Outline of their History, Development and Construction (London: Ernest Benn Limited, 1966).
} 
instrument to double the voice. ${ }^{31}$ At that time, the C-clefs (namely soprano, mezzosoprano, alto, and tenor clef) were customary for upper vocal lines as was the F-clef (bass clef) for the bass vocal line. ${ }^{32}$ Simply put, trombonists that were employed to double vocal lines were required to be literate in the variety of clefs in common use. C-clefs were used extensively before 1700 likely due to the long association of the C clef with vocal music-tracing back to the earliest use of a two-lined staff in the $11^{\text {th }}$ century, ${ }^{33}$ and as Thurston Dart elucidates:

-it was not easy to set up in type music that involved many ledger lines, and most printed music before 1700 or so (and much later music, for that matter) was set up from movable types. Consequently, the printer and the composer took some trouble to choose a clef which brought the part in question as nearly as possible within the compass of a five-line stave. ${ }^{34}$

Like most instrumental notation, the format for written trombone music-a pattern established during the Renaissance-has remained relatively static over the centuries. Nonetheless, excepting written music for viola and alto trombone, the present-day use of the alto clef is an anomaly. Innovations in scoring for trombone

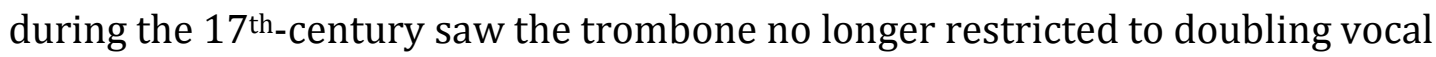
lines. This move was accompanied by a contemporaneous expansion of instrumental genres away from the imitation of vocal idioms. ${ }^{35}$ The emergent independence of the trombone from vocal music resulted in different evolutionary paths of notation; for alto vocalists, the alto clef was gradually replaced by the treble clef. A closer look at trombone notation is thereby warranted if for no other reason than to explore the factors advancing the retention of alto clef in alto trombone music.

${ }^{31}$ Gregory, The Trombone: The Instrument and its Music, p. 106.

${ }^{32}$ C. F. Abdy Williams, The Story of Notation [1903] (Reprint, New York: Greenwood Press Publishers, 1969), pp.171-172.

33 Ibid., p. 83.

34 Thurston Dart, The Interpretation of Music (New York and Evanston: Harper \& Row Publishers, 1963), p. 23.

${ }^{35}$ Herbert, The Trombone, p.91-92. 
Additional grounds to evaluate alto trombone notation are twofold. First, bearing in mind the overwhelming use of transposition in secondary wind instruments, the formative processes concerning alto trombone notation deserve comparison to the evolution of notation of other brass instruments that do, in modern format, utilize transposition. Secondly, confusion, or at least inconsistency, has surrounded composers' clef selection for trombone and long vexed the symphonic trombonist. To reiterate Piston's Orchestration:

Parts for [alto] were written ordinarily in the alto clef, and this is probably one reason for the use of the alto clef for the first and second trombones, seen in some scores even when no alto trombone is intended. ${ }^{36}$

Alto clef had frequently been used for trombone parts even when all historical evidence suggests that the composer was writing for tenor rather than alto trombone. ${ }^{37}$ Although an in-depth discussion of performance practice and instrument selection is beyond the scope of this research project, a review of alto trombone notation sheds light on which trombone is being called for in orchestral trombone parts if clef alone is not a reliable indicator of determining the alto versus tenor variety. The present foray into trombone notation shall review historical background and endeavor to illuminate the preceding points of inquiry. Retracing these angles of trombone history and revisiting the assumption that tradition offers a logical and/or practical procedure for contemporary alto trombonists will provide a point of departure for the current study.

\section{ORIGINS OF ALTO TROMBONE NOTATION}

A discussion of trombone notation begins before written music for trombones existed or, at least, before trombone music was labeled as such. Specifically notated instrumental parts, outside of solo music for keyboard or lute,

\footnotetext{
${ }^{36}$ Walter Piston, Orchestration, pp. 268-270.

37 Ibid.
} 
were uncommon for any instrument before the last part of the $16^{\text {th }}$ century. ${ }^{38}$ While the majority of ensemble music written before 1600 could therefore be designated as vocal music, it is clear that instruments played an important role in the performance of this music. ${ }^{39}$ Corroborative evidence that $16^{\text {th }}$ century trombonists were actively performing in ensembles, despite the omission of specified instrumental parts, can be found in the employment records of European churches and courts of that time. ${ }^{40}$ Although the practice was not ubiquitous, European trombonists during this period were often hired as regular/permanent employees rather than being brought in only for special occasions. In the case of Henry VIII's Royal Court of 1532, no fewer than eleven trombonists are listed as recipients of regular monthly wages! ${ }^{41}$ The absence of written music for (what can only be interpreted as) actively performing musicians suggests that these trombonists were expected to: 1) perform from memory, 2) improvise, 3) "intuitively double"-a term Herbert has provided to describe the process of doubling vocal lines even with "little or no familiarity," 42 or 4 ) read (double) parts that were originally written for voice.

The function of trombones in the $16^{\text {th }}$ century was primarily, but by no means solely, to double or substitute for vocal lines in both sacred and secular music. ${ }^{43}$ This occurred in part because of the trombone's ability to blend with the voice in terms of dynamic versatility, the pitch range of the instrument, and the ability to play in different keys. ${ }^{44}$ Trombones of this time-period projected a clarity of sound similar to that of the modern trombone, but were typically softer and produced a more mellow tone. ${ }^{45}$ The softer dynamic of the $16^{\text {th }}$ century trombone

\footnotetext{
${ }^{38}$ Willi Apel, The Notation of Polyphonic Music 900-1600 (Cambridge, MA: The Mediæval Academy of America, 1961), pp. xxi-xxii.

39 Ibid., p. xxi.

${ }^{40}$ Herbert, The Trombone, pp. 83-85, 100-106.

${ }^{41}$ Ibid., p. 84.

${ }^{42}$ Ibid., p. 92.

43 Trevor Herbert, "'Sackbut': the Early Trombone." in The Cambridge Companion to Brass Instruments, ed. Trevor Herbert and John Wallace (Cambridge, UK: Cambridge University Press, 1997), p. 75.

${ }^{44}$ Herbert, The Trombone, p. 101.

${ }^{45}$ Denis Arnold, "Con Ogni Sorte di Stromenti: Some Practical Suggestions."Brass Quarterly 2 (March
} 
was due in part to the more narrow bore size, the smaller bell, and a more conical mouthpiece. 46 There was also a difference in thickness of metal used to construct the trombones (whether thinner or thicker than today's standards is debated ${ }^{47}$ ), although acoustical research indicates that wall material has little or no effect on the amplitude or timbre of an instrument. ${ }^{48}$ That the trombone was considered to be a soft instrument is confirmed by the many writings of the time that classify the trombone with other quiet instruments such as viols or violins, recorders, and cornettos. ${ }^{49}$ Adam Carse states:

The very fact that [the trombone] was constantly used in conjunction with the old cornetts and with human voices in the performance of Church music, is in itself enough to prove that the trombone was played in such a way that its tone balanced, rather than overwhelmed, that of its associated instruments and voices. ${ }^{50}$

Nonetheless, throughout the $16^{\text {th }}$ century the trombone could be found in a variety of settings, at times grouped with loud, at times grouped with soft instruments, and by the $17^{\text {th }}$ century, the once-emphasized distinctions of loud and soft (haut and bas) instruments was largely meaningless. ${ }^{51}$

In an exceedingly rare example, the printed and published music for the Medici wedding of 1539 written by Francesco Corteccia includes parts that double the vocal lines and are specifically labeled for the trombone. ${ }^{22}$ Further evidence that $16^{\text {th }}$-century trombonists were expected to perform from written "vocal" parts must be extracted from $16^{\text {th }}$ century annotations and writings about music. For

1959): p.101.

${ }^{46}$ Adam Carse, Musical Wind Instruments: A History of the Wind Instruments Used in European Orchestras and Wind-Bands from the Later Middle Ages Up to the Present Time [1939] (Reprint, New York: Da Capo Press, 1965), p. 261.

47 David Guion, The Trombone: Its History and Music 1697-1811 (New York: Gordon and Breach, 1988), pp. 2-3.

${ }^{48}$ Strong, William and George Plitnik. Music, Speech, Audio, $2^{\text {nd }}$ ed. (Provo, Utah: BYU Press, 2005), pp. 362-363.

${ }^{49}$ Herbert, The Trombone, pp. 99-100.

${ }^{50}$ Carse, Musical Wind Instruments, p. 262.

${ }^{51}$ Herbert, The Trombone, pp. 96-97.

52 Ibid., p. 91. 
example, an anonymous set of madrigals from 1552 discovered in the Accademia Filarmonica in Verona includes one with the following annotation "with low voices arranged for the trombones,"53 and the remark "that which is good on trombones" was written on a 1538 setting of Sicut lilium by Antoine Brumel. ${ }^{54}$ Alessandro Striggio's Ecce beatam lucem, an extraordinary 40-part work written for four choirs, was performed for the 1569 marriage of Duke William of Bavaria to Renee of Lorraine. All parts in this work are provided with text for singers but a contemporary description of the event (in Massimo Troiano's Dialoghi [1569]) states that the performance included eight trombones, among various other instruments. ${ }^{55}$ The supporting evidence that $16^{\text {th }}$-century trombonists were musically literate, coupled with the trombone's association with "vocal music" explains the derivation of the alto, tenor, and bass clef in written music for trombone.

In the late $16^{\text {th }}$ - and early $17^{\text {th }}$-century, composers such as Giovanni Gabrieli and Claudio Monteverdi initiated the practice of writing specific and dedicated instrumental parts. The previously established custom of trombonists doubling alto, tenor, and bass vocal parts probably sustained the model for writing alto, tenor, and bass trombone parts in corresponding vocal clefs. During this time-period, soprano parts were likely doubled by the cornetto-the soprano trombone didn't appear until the late $17^{\text {th }}$ century and never achieved the status or widespread acceptance accorded to other members of the trombone family. ${ }^{56}$ Previously, scholars believed that the Renaissance slide trumpet was perhaps a soprano trombone, and therefore that trombone parts had been specified by Renaissance composers such as Fontaine, Franchois, and Grossin. ${ }^{57}$ These and other Renaissance composers, on occasion, explicitly called for tenor vocal lines to be doubled by

\footnotetext{
53 Herbert, The Trombone, p. 93.

54 Ibid.

${ }^{55}$ Gustave Reese, Music in the Renaissance (New York: W.W. Norton and Co., Inc., 1959), p. 487.

${ }^{56}$ Gregory, The Trombone, pg. 117.

${ }^{57}$ Reese, Music in the Renaissance, p. 35.
} 
instruments labeled as "contra tenor trompette", and "trumpetta introitus." 58 Recent research has found no conclusive evidence to support the existence of the Renaissance slide trumpet's slide mechanism casting doubt on the accuracy of referring to the slide trumpet as a manner of trombone. ${ }^{59}$ Up until Gabrieli's time, it is difficult to pinpoint which lines were to be played by trombones, as it was not yet common practice for published music to specify instrumentation. ${ }^{60}$ Rather, publishers either: 1) omitted the subject of instrumentation assuming that musicians of the day would obviously understand contemporary performance practices, or 2) included instructions such as "con ogni sorte di stromenti" (to be played on every sort of instrument)-a practice designed for marketability that unfortunately obscures any intentions of specific instrumentation that a composer may have had, to those in later centuries. ${ }^{61}$

Giovanni Gabrieli is commonly viewed as the first composer to specifically label instrumental parts. ${ }^{62}$ In his Symphoniae Sacrae (1597), Gabrieli included instrumental parts labeled for trombone, violino, viol de gamba, and cornetto. ${ }^{63}$ Unmistakably, Gabrieli's trombone scoring was not the first written music ever intended for performance on trombones. Rather, specific trombone parts offered written proof of a musical custom that was already in common practice, building on a tradition of trombone performance that had been underway since at least the middle of the $16^{\text {th }}$ century. ${ }^{64}$ Gabrieli used a variety of clefs for lines he labeled for trombone including: mezzo-soprano, alto, tenor, baritone, bass, and double-bass clef

\footnotetext{
58 Ibid., p. 35, and p. 42.

${ }^{59}$ see Peter Downey, "The Renaissance Slide Trumpet: Fact or Fiction?." Early Music 12 (February 1984): pp. 26-33.

${ }^{60}$ Egon Kenton, Life and Works of Giovanni Gabrieli, Musicological Studies and Documents, ed. Armen Carapetyan, vol. 16 (Middleton, WI: American Institute of Musicology, 1967), p. 1.

${ }^{61}$ Arnold, "Con Ogni Sorte di Stromenti: Some Practical Suggestions.", p. 99.

62 Douglass Seaton, Ideas and Styles in the Western Musical Tradition (Mountain View, CA: Mayfield Publishing Company, 1991), p. 149.

${ }^{63}$ Denis Arnold, Giovanni Gabrieli, Oxford Studies of Composers, vol. 12 (London: Oxford University Press, 1974), pp. 38-41.

${ }^{64}$ Herbert, The Trombone, p. 91.
} 
(the term used by Arnold to indicate the top-line F clef65). In Symphoniae Sacrae, Gabrieli called for as many as 12 trombones, using the instrument in isolated movements of larger works (such as in the motet In ecclesiis), and in shorter, singlemovement compositions (e.g., Sonata pian e forte). ${ }^{66}$ With the publication of Symphoniae Sacrae, Gabrieli's style of trombone writing and clef selection influenced other important Italian composers of the time such as Claudio Monteverdi. Monteverdi continued the tradition of labeling instrumental parts and of idiomatic writing for trombones in works such as Orfeo (1607) and Vespro della Beata Vergine (1610). ${ }^{67}$

Before Gabrieli's innovation of labeling instrumental lines, the use of instruments on vocal lines was implied but non-specific. Simon Karasick writes:

As was customary in those times [early Baroque], vocal and instrumental music was performed interchangeably. When the designation of altus appeared in a score it was either sung by an alto voice or played on an alto instrument [or both], which could have been an alto recorder, trombone, or other instruments, depending on the preference of the composer or what alto instruments were available. 68

By routinely labeling instrumental parts, Gabrieli and Monteverdi made clear when they had a preference for the trombone to perform altus lines. However, neither composer specified the use of the alto trombone, and clef choice does not provide conclusive evidence that the alto instrument was known at this time. Gabrieli's Symphoniae Sacrae, for example, designated the trombone for altus lines written in mezzo-soprano or alto clef, but also used alto clef for trombone parts covering the tenor lines. ${ }^{69}$

\footnotetext{
65 in Arnold's Giovanni Gabrieli, p. 37.

${ }^{66}$ Gregory, The Trombone, p. 106.

${ }^{67}$ Herbert, The Trombone, p. 106.

${ }^{68}$ Simon Karasick. "The Alto and Contrabass Trombone." Music Journal 26 (January 1968): p. 30.

${ }^{69}$ Gabrieli, Giovanni. "Sacræ Symphoniæ [1597]" in Corpus Mensurabilis Musicæ, vol. 12 (10), ed. Richard Charteris. Neuhausen, Germany: American Institute of Musicology-Hänssler-Verlag, 1998.
} 
Of particular interest in Gabrieli's and Monteverdi's instrumental compositions is the shift away from the conventional imitation and/or doubling of vocal idioms that were commonplace until this time. Through experimentation with new timbral combinations, and idiomatic instrumental patterns, composers such as Gabrieli and Monteverdi defined instrumental ensemble music as an independent and self-explanatory genre outside of dance music. This is significant because the emergence of (specifically labeled) written music for instrumentalists coincides with a fundamental change in instrumental function. As Herbert describes:

A major cultural change occurred in instrumental performance during the sixteenth century, which saw players depending more on written music. The change was not acute, neither was its pace and nature uniform across Europe. But it was part of a broad trend towards a greater autonomy for instrumental music and a greater dependency on written music, and as this process unfolded there was a commensurate shift in the balance of performance authority from performers to composers..$^{70}$

Therefore, as the Renaissance period waned, composers were expected to provide written instrumental parts, inaugurating an increasingly less flexible system of instrumental notation, and a corresponding drive towards notational standardization. The early Baroque designation of soprano, alto, tenor, and bass clef as the "chiavi naturali", or usual clefs, triggered an attenuation of mezzo-soprano, baritone, and double-bass clefs. ${ }^{71}$ The result of this trend for trombones was that during the Baroque period, the alto, tenor, and bass clefs became entrenched as the paradigm for the respective First, Second, and Third Trombone lines despite the instrument's musical function having evolved far beyond its notational origins in vocal doubling.

The implication of Gabrieli's and Monteverdi's clef choice for separate trombone lines lends credence to the notion that different types of trombones were

70 Herbert, The Trombone, p. 91.

71 Patrizio Barbieri, “Chiavette”, Grove Music Online, ed. Deane Root (Oxford University Press, 2007 2010), available at <http://www.oxfordmusiconline. com>, accessed November 14, 2009. 
in use in their day. ${ }^{72}$ Nonetheless, the assumption that a composer's selection of alto clef mandates the use of an alto trombone is precisely that. There are no surviving examples of alto trombones from the $16^{\text {th }}$ century and no irrefutable evidence that the alto instrument even existed before Michael Praetorius' treatise in 1619. ${ }^{73}$ The earliest known source of practical writings on trombone, Aurelio Virgiliano's Il dolcimelo, was published in Northern Italy circa $1600 .{ }^{74}$ Similar to what is found in Gabrieli's works, Virgiliano linked the trombone with mezzosoprano, alto, tenor, bass, and baritone clefs. Although Virgiliano's illustration ${ }^{75}$ of trombones playing on alto, tenor, and bass lines in the tradition of vocal doubling has been offered as evidence of alto trombone use, ${ }^{76}$ the "alto" trombone in Il dolcimelo is clearly shown as being pitched in "A" the same as the tenor trombone. ${ }^{77}$ In contrast, Praetorius, in the second volume of his musical encyclopedia Syntagma Musicum, ${ }^{78}$ explicitly described the four sizes of trombone in use in his day-the alto, tenor, quart/quint, and octave. Although he did not specify which clefs were used in written trombone music, Praetorius revealed that tenor trombones were the most common and sometimes used to play alto lines. The custom of alto trombone parts being performed on tenor is implied by his less-than-flattering opinion of the alto trombone:

-the musical quality produced by [the alto's] small body is not as good as that of the ordinary [tenor] sackbut, which can be used to play equally high parts after steady practice. ${ }^{79}$

then clearly spelled out in his description of the tenor trombone:

Through practice the range can be extended by two tones in either direction

\footnotetext{
72 Gregory, The Trombone, p. 106.

${ }^{73}$ Herbert, The Trombone, p. 28.

${ }^{74}$ Aurelio Virgiliano, Il dolcimelo [c. 1600], facsimile ed. (Florence: Studio per Edizione Scelte, 1979).

${ }^{75}$ see Ibid., pp. 51-52, or Herbert, The Trombone, p. 35.

${ }^{76}$ see for example Will Kimball's "Alto Trombone Timeline." Will Kimball, Trombone [online].

${ }^{77}$ Howard Weiner, personal communication, Feb. 7, 2010.

78 Michael Praetorius, Syntagma Musicum II De Organographia: Parts I and II [1619], translated and ed. by David Z. Crookes (Oxford: Oxford University Press, 1986).

${ }^{79}$ Ibid., p. 43.
} 
without any loss of tone-quality; thus the instrument can very well be used on the alto line. ${ }^{80}$

Howard Weiner has compiled additional evidence questioning the ubiquity of the alto trombone in previous centuries. ${ }^{81}$ If the alto was not as common as previously believed, then some early specified trombone parts written in alto clef were either intended for tenor trombone, or written for either the alto or tenor variety, the instrument choice being left to the trombonist's discretion. While composers may have selected alto clef for top trombone lines because of range (to avoid ledger lines), vocal doubling, or merely the previous tradition of vocal doubling, it cannot be established that alto clef was specifically chosen because it was sensible, in and of itself, to write for the alto trombone in alto clef. Although $17^{\text {th }}$-century trombonists were undoubtedly literate in alto clef, there is a fine line of distinction between a composer's clef selection being founded on accepted practice versus being founded on inherent logic. Reasoning derived from the ease of following tradition and the assent of trombonists to perform in alto clef is such that the primary benefactor is the composer. Consider again the quote from Adler's The Study of Orchestration as evidence of written music's inherent bias towards composer-based logic:

Although three types of trombones are still in general use today-the alto, tenor, and bass trombone- there are no great problems of instrument use and transposition to frustrate the composer or orchestrator. ${ }^{82}$

By comparison, logic stemming from the performer's point-of-view, centered on components such as facility of reading written parts, or transitioning between alto and tenor trombones, may have led trombonists to a different notational tradition.

Praetorius outlined one such example of performer-based logic in his

\footnotetext{
80 Praetorius, Syntagma Musicum II, ed. Crookes, p. 43.

${ }^{81}$ Howard Weiner, "When is an Alto Trombone an Alto Trombone? When is a Bass Trombone a Bass Trombone?-The Makeup of the Trombone Section in Eighteenth- and Early NineteenthCentury Orchestras." Historic Brass Society Journal 17 (2005): p. 70.

82 Adler, The Study of Orchestration, p. 312.
} 
Syntagma Musicum. The quart or quint trombone that Praetorius described was pitched in either $E$ or $D$, an octave lower than the alto pitched in $E$ or $D$, and a perfect fourth or fifth lower than the tenor pitched in A. ${ }^{83}$ Praetorius advocated a method of transposition for the quint trombone in which the trombonist uses clef visualization. To Praetorius, the tenor trombone was the "ordinary" trombone (meaning most common), and he suggested that a musician learning the quint trombone would already be familiar with playing the tenor. In his words:

Anyone who can play the ordinary sackbut [tenor] mentioned above will have no difficulty with one of this type [quint], provided that he imagines everything he has to play is a $5^{\text {th }}$ higher, and mentally substitutes:

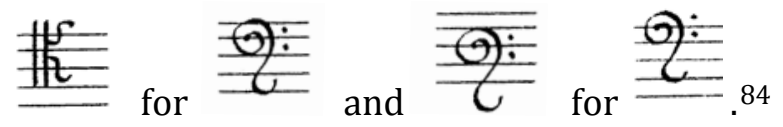

Praetorius' treatise contains both theoretical and instructional information, and likely included the mention of clef visualization because it was a technique already in use by trombonists of his day. Knowing that trombonists were literate in various clefs, Praetorius nonetheless espoused the concept of transposition for (what was known to him as) a secondary trombone. Obviously, Praetorius believed clef visualization to be the more practical approach-compared to relearning all the positions for the written pitches-for the tenor trombonist to learn to play the quint trombone.

Unfortunately, Praetorius did not provide comparable insight into the performance practice of the alto trombone. Clef visualization for alto trombonists is neither cited nor proposed by Praetorius and is thus unlikely to have been in common practice. Precluding the implausible-that $17^{\text {th }}$-century alto trombonists were alto-only specialists, and thus confined to reading only the limited number of clefs found in alto lines-certainly Praetorius missed the opportunity to promote the potential utility of transposition for tenor trombonists doubling on alto. Two factors

\footnotetext{
${ }^{83}$ Herbert, "'Sackbut': the Early Trombone." in The Cambridge Companion to Brass Instruments, p. 72. ${ }^{84}$ Praetorius, Syntagma Musicum II, ed. Crookes, p. 43.
} 
likely contributed to this oversight. First, the clef visualization technique is not so accessible on alto trombone, as it would require parts written in alto clef to be interpreted in a non-existent top-space C-clef, ${ }^{85}$ or to be coupled with a system of note visualization. ${ }^{86}$ Secondly, the more practical method of aiding tenor trombonists doubling on alto-writing music at a transposition-was a concept still nascent; the first use of instrumental transposition came about in $17^{\text {th-century }}$ German trumpet music. ${ }^{87}$ Therefore, the time was not right for Praetorius, or the trombonists he knew, to challenge tradition with a conceptual leap of this magnitude, despite the inherent simplicity and practical outcome of the application of transposition in alto trombone notation. Nonetheless, the use of alto clef based solely on the preference of alto trombonists for reading alto clef is equally unlikely; a notational tradition born of necessity (doubling vocal music), and propagated by the emerging authority of the composer suggests otherwise.

\section{ALTO CLEF PERSEVERANCE}

If not for an inherent performer-based logic, what then other than tradition has mandated the inertia of standard notational practice for the alto trombone? What accounts for the perseverance of alto clef for alto trombone throughout centuries of notational reform? In an assessment of general modern notational procedure, The Grove Dictionary of Music and Musicians states:

In practice, notational reform has tended to abolish the $\mathrm{C}$ clefs, substituting $\mathrm{G}$ clefs with octave transpositions where necessary (mainly for the tenor voice and some wind instruments) but retaining the F clef, as in keyboard music... Traditional C

\footnotetext{
${ }^{85}$ Based on the likelihood that Praetorius knew tenor trombones to be pitched in A, and alto trombones to be pitched in D, see Weiner's "When is an Alto Trombone...", p. 37.

${ }^{86}$ For example, in Anderson's use of clef visualization coupled with note visualization formalized as "Method No. 3" in his Complete Method for Eb Alto Trombone, vol. 1, p. ii.

${ }^{87}$ Anthony Baines and Janet Page, "Transposing Instruments, §3: Brass." Grove Music Online, ed. Deane Root. Oxford University Press, 2007-2010. Available at <http://www. oxfordmusiconline.com>, accessed October 23, 2009.
} 
clefs remain standard [only] for music for the viola and trombone, and for the high registers of the cello and bassoon. ${ }^{88}$

As early as 1529 , an evaluation of the system of clefs was requisitioned by the German theorist Sebald Heyden, 89 and during the $17^{\text {th }}$ and $18^{\text {th }}$ centuries, the growing urgency for a reduction in the diversity of clefs is evidenced by the number of proposals for clef reform. ${ }^{90}$ Some clef reform proposals called for a single clef (e.g., Juan Caramuel's Ars Nova Musicae in 1645); others called for the elimination of all but the G and F clefs (e.g., Grétry's Mémoires, ou Essais sur a Musique in 1789). ${ }^{91}$ Of the multiple types of clef that were commonplace in instrumental music at the beginning of the $17^{\text {th }}$ century (see Example 1) modern convention has reduced the clefs to four: treble, alto, tenor, and bass. Of the three varieties of clef (G-, F-, and Cclefs), only the C-clef continues to function with a non-fixed staff placement.

\section{Example 1-Clef Varieties}

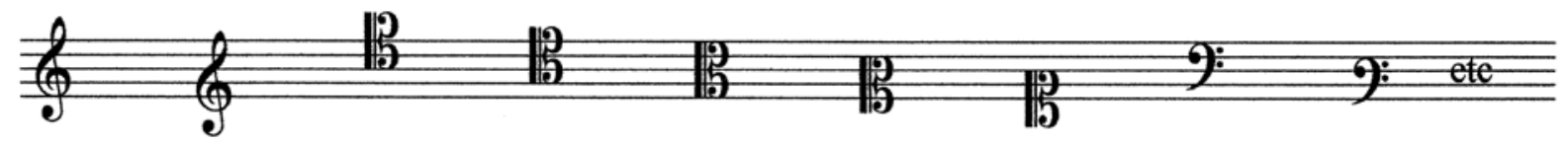

The four instruments identified in The Grove Dictionary that have retained the use of C-clefs do so primarily to avoid an overabundance of ledger lines. ${ }^{92}$ In modern practice, upper register tenor trombone, cello, and bassoon parts employ tenor clef (sometimes temporarily) in order to avoid ledger lines in bass clef. Viola parts are rooted in alto clef to avoid the complexity of ledger lines that would exist

\footnotetext{
${ }^{88}$ Geoffrey Chew and Richard Rastall, "Notation, §III, 4: Mensural notation from 1500: (v) Clefs, staves, and leger lines." Grove Music Online, ed. Deane Root. Oxford University Press, 20072010. Available at <http://www.oxfordmusiconline.com>, accessed July 23, 2009.

${ }^{89}$ Although Heyden promoted the abolishment of clefs, such a move is not entirely possible aside from the use of tablature. As Rastall reminds in his Notation of Western Music (p. 250) "-a clefless staff is merely a staff with a fixed clef implied."

${ }^{90}$ Williams, The Story of Notation, pp. 253-256.

${ }^{91}$ Chew and Rastall, "Notation, §III, 4: Mensural notation from 1500: (v) Clefs, staves, and leger lines." Grove Music Online. 92 Ibid.
} 
with parts written in either treble or bass clef. ${ }^{93}$ Although there is no specific mention of the alto trombone in Geoffrey Chew and Richard Rastall's entry, the normal concert-pitch register of the alto trombone is similar to the viola (excepting the viola's upper treble range); thus, the use of alto clef to avoid ledger lines is seemingly justified for alto trombone. Of course, unlike the viola, the alto trombone does not stand on its own as an instrument, instead being historically and presently secondary to the tenor trombone. Therefore, to justify clef choice on the criterion of range and ledger lines not only assumes the cruciality of the alto's standing as a nontransposing instrument but also affords the alto greater status-in terms of the instrument's applied function and the prerequisite for a trombonist to be able to maneuver from primary instrument (tenor) to secondary (alto)-than history has given precedent.

Obviously, the influence of tradition plays a key role in maintaining the relevance of alto clef to the alto trombone. It was not until the twentieth century that a progressive consideration of the alto trombone as a transposing instrument was formalized. ${ }^{94}$ While the authority of musical tradition should never be challenged without warrant, the convention of non-transposing alto trombone notation is unusual in comparison to the contemporary notational practices of other brass instruments such as horn and trumpet. Hornists and trumpeters may maneuver between instruments pitched in different keys without a change in the visual feedback of the notation. Broadly speaking, modern trumpet and horn notation includes the use of transposition due to the evolution of the instruments' musical function. The trombone's diatonic/chromatic nature helped formulate its primary role in the Renaissance to be vocal doubling, requiring trombonists to be literate in the various vocal clefs then in use. Other brass instruments, such as trumpet and horn, came to be notated using transposition-a system that is perhaps

\footnotetext{
${ }_{93}$ Kennan and Grantham, The Technique of Orchestration, p. 20.

${ }^{94}$ Method Books that explore the use of transposition for alto trombone will be addressed in subsequent chapters of the current study.
} 
more idiomatic and inherently more logical, particularly in terms of transitioning between instruments pitched in different keys.

\section{HORNS, TRUMPETS, AND TRANSPOSITION}

The historical context of the alto trombone's concert-pitch notational tradition can be better understood by a comparison to the notational practices of other brass instruments. The use of transposition in trumpet and horn parts launched a significant new direction in brass instrument writing that resulted in a system designed to facilitate switching between the varieties of each instrument. The instrumental use of transposition first appeared in $17^{\text {th }}$ century German trumpet parts. ${ }^{95}$ Following the introduction of the horn into the orchestra during the early $18^{\text {th }}$ century and the inevitable increase in the number of keys required of brass players, transposition for trumpet and horn parts became a nearly universal practice. ${ }^{96}$ Excepting pitches manipulated by embouchure or by hand-in-bell placement, eighteenth-century horns were largely confined to the open notes of the harmonic series based on a particular fundamental pitch. The fundamental, or "key" of the horn could be altered by inserting a coiled piece of tubing known as a crook. The crook lengthened the horn's overall tubing slightly, thereby created a new harmonic series dependent upon the length of crook. It became conventional for horn parts to be notated in treble clef in the key of $\mathrm{C}$ major with the composer merely specifying which crook was to be used. ${ }^{97}$ This likely occurred because either: 1) it was easier for hornists to read the available partials of the harmonic series in $\mathrm{C}$ major regardless of the difference in sounding pitch, or 2) it was easier for a composer to write for the horn using this method. With this system of notation, a written $\mathrm{c}^{2}$ would sound the note $\mathrm{f}^{1}$ if played on a horn with the " $\mathrm{F}$ " crook, a g ${ }^{1}$ if played on a horn with the "G" crook, etc. ${ }^{98}$ This notational system was also

\footnotetext{
95 Baines and Page, "Transposing Instruments, §3: Brass." Grove Music Online.

${ }^{96}$ J. Murray Barbour, "Unusual Brass Notation in the Eighteenth Century."Brass Quarterly 2 (June 1959): p. 139.

${ }^{97}$ Ibid.

${ }^{98}$ For the duration of this document, specific pitch indications will follow International Trombone
} 
applied to trumpets, and later clarinets, and some other woodwinds. ${ }^{99}$ Before the advent of valves in the early nineteenth-century, it was probably not too critical how the pitches for brass instrumentalists were notated because, so long as the composer specified which crook to use, the written pitches-following only the available notes of a given harmonic series-could be interpreted by a competent performer. ${ }^{100}$ In this way, the performer required only a notation that expressed harmonics rather than absolute pitches. ${ }^{101}$

The advantage of a system of notational transposition is that it allows performers to switch instruments, or crooks, for the purpose of playing in different keys, while maintaining a consistent visual feedback. The earlier quote from Alfred Blatter corroborates that transposition is traditionally for the conceptual benefit of the performer:

Usually, an instrument is written as a transposing instrument so that a performer may transfer eye-and-hand coordination skills learned on one family member to another family member. ${ }^{102}$

Eighteenth-century horns briefly used a system of clef visualization similar to the one suggested by Praetorius for the quint trombone. As the system of transposition was relatively new, there was an implicit assumption that a conductor reading the score might not be able to accurately read horn parts at a transposition. This led to the development of a method where horn parts were written in a variety of clefs, but the hornist would visualize the part in treble clef. If the composer had selected a corresponding clef and correct pitch of horn, the score could be read at concert pitch while the horn notes sounded at the appropriate transposition. ${ }^{103}$ By the close of the $18^{\text {th }}$ century this system faded into obscurity; the onus of score transposition

Association (ITA) convention, see Appendix A.

${ }^{99}$ Richard Rastall, The Notation of Western Music (New York: St. Martin's Press, 1982), p. 229.

100 Barbour, "Unusual Brass Notation in the Eighteenth Century.", p. 139.

101 Baines and Page, "Transposing Instruments, §3: Brass." Grove Music Online.

102 Blatter, Instrumentation/Orchestration, p. 10.

${ }^{103}$ Adam Carse, The History of Orchestration (New York: Dover Publications, Inc., 1964), pp. 114-115. 
was reinstated to the conductor. The frequent inaccuracies in clef selection that resulted in confusion and error in the score were a significant contributor to the demise of this transpositional method. ${ }^{104}$

With the introduction of the valve in the early $19^{\text {th }}$ century, horns and trumpets no longer had as much need to utilize crooks, or instruments pitched in different keys. The rise in popularity of the early two-valved cornet (designed circa 1828) eventually prompted brass instruments to be constructed with a full complement of three valves, which allowed a complete range of chromatic notes. 105 With fully chromatic valved brass instruments, crooking or varying fundamental pitch is largely redundant except for timbral considerations. Hypothetically, if the standard for trumpeters was to always use the same instrument (e.g., trumpets always in C) then writing trumpet parts at a transposition would be superfluous. Current practice, however, finds that trumpeters commonly switch between $\mathrm{Bb}$ and $\mathrm{C}$ pitched instruments, and that $\mathrm{D}$ or Eb trumpets are used for historical works originally scored for those instruments. ${ }^{106}$ For trumpeters, the advantage is being able to read the same written notes, know the same fingerings, adjusting only for the difference in sounding pitch. Of course, proficient trumpeters are also adept at visual transposition; the register of a work, availability of an instrument, or personal preference could prompt a performer to select a trumpet other than the one called for by the composer. ${ }^{107}$ Hornists are less likely than trumpeters to switch to different pitched instruments. Nonetheless, hornists have maintained the use of transposition due to the register of the horn in F; concert-pitched parts for this instrument require a continual shifting between the treble clef and bass clef. The alto clef might be a logical choice for concert pitch horn parts, but with no historic precedent and offering no advantage that outweighs tradition or the ability to read

${ }^{104}$ J. Murray Barbour, Trumpets, Horns, and Music (East Lansing, MI: Michigan State University Press, 1964), p. 8.

${ }^{105}$ Scott Whitener, A Complete Guide to Brass, $3^{\text {rd }}$ ed. (Belmont, CA: Thomson Schirmer, 2007), p. 132. ${ }^{106}$ Andrew Stiller, Handbook of Instrumentation (Berkeley, CA: University of California Press, 1985), p. 79. 107 Ibid., p. 76. 
horn parts pitched in different keys. ${ }^{108}$ Similar to other accepted notational traditions such as scoring viola parts in alto clef, for horn in F, the primary status of the instrument justifies the use of transposition in written horn music.

\section{TROMBONE NOTATION AT THE DAWN OF ROMANTICISM}

In the beginning of the $18^{\text {th }}$ century, horns and trumpets acquired crooks and were introduced into the orchestra. ${ }^{109}$ This resulted in notational variants that eventually settled on utilizing the treble clef in C. ${ }^{110}$ The complexities of the $17^{\text {th }}$ century church-tone and chamber-tone systems of Bach and Handel (that resulted in Bach writing for D trumpets at a transposition and Handel writing for D trumpets at concert pitch ${ }^{111}$ ) were resolved during the latter $18^{\text {th }}$ century. ${ }^{112}$ While the horn and trumpet took on significant structural and notational adjustments throughout the $18^{\text {th }}$ century, the trombone family changed only on a conceptual level. With the publication of André Braun's Gamme et Méthode pour les Trombonnes in 1793 or 1797,113 the trombone's theoretical shift from four slide positions (diatonic) to seven slide positions (chromatic) was formalized. Braun was also the first to record the tenor trombone as having a nominal fundamental pitch of Bb instead of A, just as he listed the alto trombone as being pitched in Eb, instead of in E or D. ${ }^{114}$ Unlike other brass instruments, the trombone did not acquire any significant structural changes until 1839 when Sattler procured the optional F-attachment valve.115 As notational developments for horn and trumpet stabilized, the trombone suffered a peculiar dilemma. Except in Vienna, $18^{\text {th }}$-century trombone use in Europe had

\footnotetext{
${ }^{108}$ Baines and Page, "Transposing Instruments, §3: Brass." Grove Music Online.

109 Thomas Hiebert, "The Horn in the Baroque and Classical Periods." in The Cambridge Companion to Brass Instruments, ed. Trevor Herbert and John Wallace (Cambridge, UK: Cambridge University Press, 1997), p. 104.

110 Barbour, Trumpets, Horns, and Music, p. 1.

111 Ibid.

112 Bate, The Trumpet and Trombone, p. 213.

${ }^{113}$ Howard Weiner, “André Braun's Gamme et Méthode pour les Trombonnes: The Earliest Modern Trombone Method Rediscovered." Historic Brass Society Journal 5 (1993): p. 288.

${ }^{114}$ Herbert, The Trombone, p. 36.

115 Ibid., p. 196.
} 
spiraled into a state of decline. ${ }^{116}$ Herbert writes:

Surviving documents from across Europe bear witness to a remarkable decline in the trombone's popularity at the end of the seventeenth century. There were a few countries where this did not occur, but generally the pattern was similar. The most notable feature of this fall from grace is that it took place relatively suddenly. The trombone was still widely in use in the 1670 s, but within a couple of decades it was either obsolete or to be found only in town bands where the older traditions were slow to die. ${ }^{117}$

Although the tenor instrument was reinstated by composers in the $19^{\text {th }}$ century, the alto trombone drifted into obscurity until its mid-20th-century revival. This period of regression in trombone use, followed by the further neglect of the alto variety during the Romantic era, inadvertently immobilized alto trombone notation. During a time when many instruments (including the tenor trombone) took on some degree of notational reform, the dwindling usage of alto trombone helped mire the instrument in a Renaissance-era notational format.

Guion points out that in the $18^{\text {th }}$ century:

-the use of trombone was at once less extensive and less conspicuous than in either the seventeenth or nineteenth centuries. ${ }^{118}$

Although exceptions exist, ${ }^{119}$ the $18^{\text {th }}$ century marks a time-period when the trombone was proportionately ignored by composers and instrumentalists. German musician Christian Schubart attested to the severity of the instrument's setback in 1784:

Since [the trombone] is so greatly neglected today and the performance is left to wretched cornett players, so it is that our music directors should take into preferential consideration the reawakening of this divinely authorized

\footnotetext{
116 Ibid., p. 109.

117 Herbert, The Trombone, p. 109.

118 Guion, The Trombone: Its History and Music 1697-1811, p. 1.

119 Guion's oeuvre provides a thorough examination of this topic.
} 
instrument. . .120

During this period of trombone debility, a budding publishing and music-printing industry was further advancing instrumental notational practice towards standardization. ${ }^{121}$ As music became less the sole domain of church and court, instead relying on public patronage, the need for organized music distribution arose. $^{122}$ As George Stauffer explains:

In the late eighteenth century the newly established orchestra stirred audiences and may be said to have started a concert industry, one requiring suitable halls, a corps of skilled instrumentalists, reviewers, and gifted composers. To keep this industry flourishing, an additional agent was necessary: publishers. ${ }^{123}$

With no prerequisite for written trombone music to accommodate physical modifications (as was the case for trumpets and horns), and the trombone itself scarcely in use, publishers and composers would have had no compelling reason to mistrust traditional trombone notation, no matter how archaic or impractical this notation may have been. Therefore, at the close of the $18^{\text {th }}$ century, with the full spectrum of trombone potential yet to be realized, the trombone's notational status quo was not only sustained by the inertia of tradition, but in fact bolstered by the music printing industry's drive towards conformity.

The notation set forth in Braun's Gamme et Méthode pour les Trombonnes adheres to the traditional alto, tenor, and bass clef trio. By the 1840s, as codified with the publication of Berlioz's Treatise on Instrumentation and Orchestration in 1844 , tenor trombone notation had expanded to include a combination of tenor and bass clef. One explanation for the addition of bass clef to tenor trombone lines is

${ }^{120}$ Christian Friedrich Daniel Schubart, Ideen zu einer Aesthetik der Tonkunst [1784-5], reprinted in Guion, The Trombone: Its History and Music 1697-1811, p. 86.

121 George Stauffer," The Modern Orchestra: A Creation of the Late Eighteenth Century." in The Orchestra: Origins and Transformations, ed. Joan Peyser (New York: Charles Scribner's Sons, 1986), pp. 37-38.

122 Ibid.

123 Ibid., p. 57. 
found in the musical traditions of late $18^{\text {th }}$-century France. Starting in Paris, the musical function of the tenor and bass trombones had become nearly interchangeable. At this time, having a single $\mathrm{Bb}$ trombone double the stringed bass line was customary in French opera houses. ${ }^{124}$ In 1811, Joseph Fröhlich's Vollständige theoretisch-pracktische Musikschule confirmed what Braun had earlier implied-that the bass trombone in use was pitched in $\mathrm{Bb}$ the same as the tenor, unlike the "quart" or "quint" bass trombone previously described by Praetorius and others. ${ }^{125}$ Fröhlich remarked:

It is better, to be sure, when the construction of the trombones is different, so that the bass and tenor trombones are distinguished not in regard to their fundamentals, but certainly in regard to the size of the bell, the length of the pipe, etc., because the former has more to do with low notes and the latter with middle notes. ${ }^{126}$

In France, the employment of $\mathrm{Bb}$ trombones for both tenor and bass lines, and the subsequent popularity of three tenor trombones in place of the traditional altotenor-bass orchestral trio ${ }^{127}$ may have impacted the intermixing of tenor and bass clef in trombone parts of this time. Outside of France, the transition to Bb bass trombone was persuaded by Sattler's supplementary trigger mechanism, labeled the F-attachment because it was originally designed to enable tenor trombones to cover the range of the bass trombone pitched in F. 128

A second reason that $19^{\text {th }}$-century tenor trombone notation expanded to include bass clef is because the range of the instrument was being explored. ${ }^{129} \mathrm{~A}$ renewed compositional interest in trombones at the onset of the $19^{\text {th }}$ century led to advances in instrument design that resulted in an increase in the bore size of the

\footnotetext{
${ }^{124}$ Herbert, The Trombone, p. 137.

125 Weiner, “André Braun's Gamme et Méthode pour les Trombonnes: The Earliest Modern Trombone Method Rediscovered.", p. 288.

126 Joseph Fröhlich, Vollständige theoretisch-pracktische Musikschule [1811], reprinted in Guion, The Trombone: Its History and Music 1697-1811, p. 112.

${ }^{127}$ Herbert, The Trombone, p. 137.

128 Ibid., p. 196.

129 Ibid., p. 41.
} 
tenor. ${ }^{130}$ This improved the sound quality of the trombone's low range, particularly for pitches at the bottom and beneath the bass clef staff, making a singular and unyielding use of tenor clef for tenor trombone impractical. The lowest viable note for tenor trombone put forth by Fröhlich in 1811 is the a-sharp just beneath the tenor clef staff (A\#). Compare this to Berlioz's use of "pedal" BBb's and AA's in the $2^{\text {nd }}$ tenor trombone part in Movement IV (measures 105 through 108) of Symphonie Fantastique in 1830. ${ }^{131}$ There is no question that the second part is intended for a tenor trombone but a strict adherence to tenor clef would have made the reading the part awkward at best (see Example 2).

Example 2-Pedal Notes in Bass Clef versus Tenor Clef

-as Berlioz wrote the part...

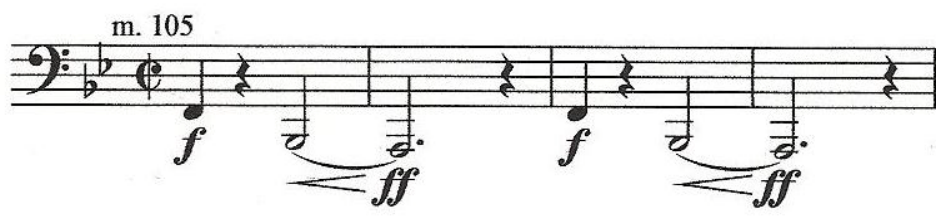

-as the part would appear in tenor clef...

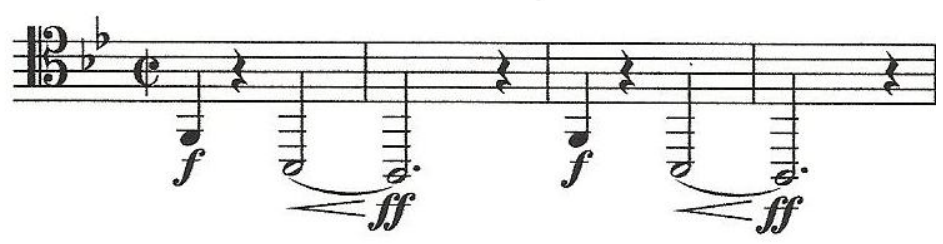

Berlioz admitted that pedal notes were atypical for trombonists of the day, but nonetheless extended the hypothetical range of the tenor down to "pedal" GG:

-[trombones] possess at the extreme low end and starting from the first natural tone downward four additional tones, tremendous and magnificent on the tenor

130 Ibid., p. 22.

131 Hector Berlioz, Fantastic Symphony [1830]: An Authoritative Score, Historical Background, Analysis, Views and Comments, ed. Edward T. Cone. Norton Critical Scores (New York and London: W. W. Norton and Company, 1971), pp. 133-134. 
trombone, indifferent on the alto trombone, and terrible on the bass trombone-if they can be produced at all. They are called pedal tones ... It is rather difficult to use them well and they are even unknown to many trombone players. ${ }^{132}$

Modern notational practice has retained the combination of bass and tenor clef for the tenor trombone. 133

Tenor trombone notation achieved its current format of tenor and bass clef during the mid-19th century, ${ }^{134}$ one of the outcomes of a resurgence of compositional interest in the tenor and bass trombone. The alto trombone, on the other hand, was effectively abandoned following the demands of an expanded and louder Romantic orchestra, and/or the increased high-register abilities of tenor trombonists. ${ }^{135}$ Due to the practical nature of applied notational renovations (in terms of the benefit to either performer, composer, or both), a further assessment of trombone notation, which might have specifically confronted the (non)sensibility of traditional alto notation, was undoubtedly rendered irrelevant due to the fact that the alto trombone was nearly obsolete by the turn of the century. ${ }^{136}$ During the period of trombone history that provided physical and notational modernizations for the tenor trombone, the alto receded into dormancy. Thus, until the rebirth of the alto in the mid- $20^{\text {th }}$ century, the tradition of alto clef for alto trombone was again upheld-not by principles of logic or performer partiality, but in this case owing to neglect.

\section{EQUIVOCAL NOTATION: ALTO OR TENOR TROMBONE?}

Early $20^{\text {th }}$-century composers who helped resuscitate writing for alto

\footnotetext{
132 Hector Berlioz and Richard Strauss. A Treatise on Modern Instrumentation and Orchestration [1844/1904], trans. Theodore Front (New York: Edwin F. Kalmus, 1948), p. 299.

133 Kennan and Grantham, Technique of Orchestration, p. 147.

134 albeit with a few deviations along the way-see next section.

135 Mathie, The Alto Trombone: Twentieth-Century Performance Practices and Pedagogy in the United States, p. 33. 136 Ibid.
} 
trombone, also unwittingly revived the preconception of notating alto trombone parts in concert-pitch alto clef. The alto trombone, having been largely inert during the closing decades of the $19^{\text {th }}$-century, had evaded the kind of notational scrutiny that many other instruments had received. When writing for the alto resumed in the early $20^{\text {th }}$ century, composers-with little else but a nearly obsolete tradition to consult-resorted to an alto trombone notation still enmeshed in a Renaissance-era archetype. Schoenberg, for example, adopted traditional concert-pitch alto clef notation when he specified alto trombone use in works such as Pelleas et Melisande (1903) and Gurre-Lieder (1911), and with the notable exception of Alban Berg, most

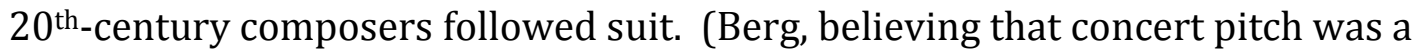
trombonist's foremost consideration, acquiesced to his editor's request to print alto trombone parts in tenor clef. ${ }^{137}$ ) The assumption that a traditional orchestration in alto clef would offer the most logical approach to alto trombone was not formally challenged by $20^{\text {th }}$-century composers. Rather, transposition was championed by trombonists themselves, as a means of making the alto trombone more accessible. The resultant methods and publications that promote the use of alto trombone transposition will be assessed in Chapters II and III of the current study. For contemporary trombonists, transposed alto trombone parts remain of limited availability; the transposing alto method has not yet gained widespread consensus among composers or trombonists. However, the historic relationship between trombone parts written in concert-pitch alto clef and the alto trombone is not one of reciprocal simplicity. While the alto trombone has sustained a persistent correlation with the use of alto clef, the use of alto clef does not mandate that a composer has written for the alto trombone. This portion of the current study serves to clarify the triangular relationship between alto clef, alto trombone, and tenor trombone by focusing on some of the notational variations found in orchestral compositions. This section is not intended as a comprehensive analysis of notational variations and instrument selection, but rather as an overview in order to further secure an understanding of the historical characteristics of alto trombone notation.

${ }^{137}$ Hartman, The Use of Alto Trombone in Symphonic and Operatic Orchestral Literature, p. 49. 
With the revitalization of the alto trombone commencing in the mid-20th century, many trombonists and conductors sought historically accurate instrumentation for top trombone parts. Sluchin proposed that the obligation of modern trombonists was:

-to use the alto in every situation in which the part was originally conceived for this particular instrument. ${ }^{138}$

Unfortunately, the question of clef and trombone choice in many works prior to the mid-twentieth century remains a point of uncertainty for performers; tenor trombone parts written in alto clef, or vice versa, and inaccuracies in labeling have made it difficult for the modern trombonist to be confident about which trombone is called for in certain compositions. Clef choice alone does not signify the composer's intentions, ${ }^{139}$ a problem that manifests itself particularly in trombone parts of the mid-19 $9^{\text {th }}$ century. During this time, the orchestral use of the alto trombone was quickly becoming overshadowed by the tenor. ${ }^{140}$ Orchestral scores can be similarly deceptive. For example, Schubert's scores were published with the top two trombone parts in tenor clef even though the composer had intended the first part for an alto trombone. ${ }^{141}$ Schumann, by contrast, placed the first two trombones on a single stave of alto clef, even though he had intended his second trombone to be a tenor. ${ }^{142}$ In both of these cases, it was likely a matter of scoring convenience for composer or publisher, to minimize ledger lines, or perhaps determined by the available number of staves on the score paper. ${ }^{143}$

Compounding the inconsistencies in clef and instrument variety, composers have occasionally labeled orchestral trombone section parts as alto, tenor, and bass

138 Benny Sluchin, “Alto or Tenor Trombone: Open or Closed Case?." Historic Brass Society Journal 5 (1993): p. 309.

139 Slocombe, "Fall and Rise of the Alto Trombone: 1830-2000." British Trombone Society [online].

${ }^{140}$ Herbert, The Trombone, p. 166.

${ }^{141}$ Shifrin, "The Alto Trombone in the Orchestra 1800-2000." British Trombone Society [online].

142 Ibid.

${ }^{143}$ Herbert, The Trombone, p. 165. 
regardless of intended or available instrumentation. ${ }^{144}$ Shifrin notes that Brahms, for example, designed his orchestral first trombone parts to be taken by an alto:

However, it remains to be seen whether Brahms' wishes regarding the alto were always respected, even during his lifetime, for this was a period in which the tenor trombone was rapidly and conclusively eclipsing the alto. Surely, more often than he would have preferred, Brahms was compelled to accept the fact that the number of trombonists who could play or even owned an alto was rapidly dwindling, and resign himself to making do with the resources at hand. Indeed, even in Vienna, it appears Brahms could not always count on getting the trombone section he intended: Archival material strongly suggests that in the first performances of Symphony No. 1 and Symphony No. 2, the trombonists used valved instruments. ${ }^{145}$

Although alto trombone availability is no longer at issue, a more pervasive uncertainty regarding instrumentation stems from imprecise labeling. For example, Dvorak's first trombone parts are routinely published in alto clef and identified in print as "Alto Trombone" even though he probably wrote for an orchestral trombone section of two tenor and one bass valved trombones. ${ }^{146}$ Similarly, there is no historical evidence to support that the "Alt-Posaune" labeled first parts of Bruckner's symphonies-originally written in bass or tenor clef-were meant for or ever performed on anything other than a tenor trombone. ${ }^{147}$

This mislabeling tendency, and the resultant lack of clarity, was admonished by Berlioz:

Unfortunately, many composers obstinately insist on indicating in their scores alto trombones, tenor trombones, and bass trombones instead of tenor trombones I, II, III, although they know quite well that most of our orchestras have only tenor trombones. Consequently, in order to perform these works elsewhere exactly as in

\footnotetext{
144 Ibid.

${ }^{145}$ Shifrin, "The Alto Trombone in the Orchestra 1800-2000." British Trombone Society [online].

${ }^{146}$ Ken Shifrin, "Trombone Myth Busters No. 1: Dvorak Wrote for the Alto Trombone." ITA Journal 25 (Spring 1997), p. 30.

${ }^{147}$ Shifrin, "The Alto Trombone in the Orchestra 1800-2000." British Trombone Society [online].
} 
Paris, it would be necessary to disregard the composer's indications and use the same instruments as in Paris. But can such interpretation of the composer's intentions be permitted at all? Would this not open the door to all sorts of distortion and abuse? Is it not more just to let those composers who are so negligent in marking their works suffer a little, rather than let others who write theirs carefully and with an exact knowledge of instrumental resources run the risk of seeing their scores disfigured? ${ }^{148}$

In adherence to his principles, the first trombone parts of Berlioz's earlier works, such as Symphonie Fantastique [1830], were published in alto clef and indeed intended for the alto trombone. (It should be noted that contemporary orchestras rarely employ the alto trombone in works such as Symphonie Fantastique due to considerations of section balance and dynamic range. ${ }^{149}$ ) By 1835, Berlioz was writing his first trombone parts in tenor clef, presumably marking the shift in Berlioz's intention for first trombone parts to be performed on tenor trombone. ${ }^{150}$ Later $19^{\text {th }}$-century Russian composers, only partially heeding Berlioz's counsel regarding mislabeling, dropped the nominal designation of "Alto" but chose to score both first and second trombone parts in alto clef. 151 The alto trombone was either ignored or unknown to Russian composers of this time, not even receiving mention in Rimsky-Korsakov's otherwise extensive Principles of Orchestration (1913). ${ }^{152}$ The Russian custom of scoring the top two trombone parts in alto clef (in this case intended for two tenor trombones) may have initially been adopted from Schumann's earlier paradigm ${ }^{153}$ but persisted in the works of composers such as Glazunov and Gliere, all the way through the compositions of Shostakovich and Prokofiev. ${ }^{154}$

\footnotetext{
${ }^{148}$ Berlioz and Strauss, $A$ Treatise on Modern Instrumentation and Orchestration, p. 299.

${ }^{149}$ Hartman, The Use of the Alto Trombone in Symphonic and Operatic Orchestral Literature, p. 39.

${ }^{150}$ Hugh Macdonald, Berlioz's Orchestration Treatise: A Translation and Commentary (Cambridge: Cambridge University Press, 2002), p. 209.

${ }^{151}$ Herbert, The Trombone, p. 165.

152 Ibid.

153 Norman Del Mar, Anatomy of the Orchestra (Berkley: University of California Press, 1981), p. 312.

154 Slocombe, "Fall and Rise of the Alto Trombone: 1830-2000." British Trombone Society [online].
} 
In a few rare cases of $20^{\text {th }}$-century orchestral literature, tenor trombone parts were designed to be doubled on alto even though conventional concert-pitch alto clef notation was not used. In Mahler's Symphony No. 6 (1903-1904), he indicated that a single phrase of the first trombone part was to be played on the alto trombone. In measures 561-565 of Movement IV, the first trombone part is marked "auf Alt-Posaune zu spielen" (to be played on an alto trombone). The line is doubled with the first trumpet and is written in bass clef (non-transposed) at a pianissimo dynamic. There is evidence that this phrase is likely to have been written for alto trombone for the purpose of achieving a specific timbre, as opposed to having been written for high range or soft dynamic considerations. ${ }^{155}$ Mathie provides examples of other Mahler symphonies that include high and soft first trombone parts where the alto is not suggested. Similarly, Mahler designated a single phrase of his Symphony No. 7 (1908) as "eventuell auf Alt-Posaune zu blasen" (possibly to be played on an alto trombone). This time the phrase suggested for alto trombone is written in tenor clef and doubles the first horn at pianissimo. ${ }^{156}$ Although Mahler's use of alto trombone is novel, Mathie also found that of the orchestral trombonists surveyed for his research, none had ever actually performed either of these four measure phrases on an alto trombone..$^{157}$

In order to simplify the task of the modern trombonist in choosing an historically accurate instrument, notational variations that exist for the orchestral trombone section have been surveyed. Table 1 shows some of the more common arrangements of clef and intended instrumentation for the standard orchestral trombone trio, and includes examples of composers who used this notation. The clef/instrumentation models in Table 1 include only groupings that incorporate alto trombone and/or alto clef. In order to further clarify orchestral alto usage, Appendix B provides a compiled list of common orchestral works that trombone scholars have suggested as historically appropriate for the alto trombone. Appendix

\footnotetext{
155 David Mathie, The Alto Trombone: Twentieth-Century Performance Practice and Pedagogy in the United States, p. 65.

156 The phrase is found in Movement I, beginning at rehearsal number 39.

157 Mathie, The Alto Trombone..., p.66.
} 
B does not include any First Trombone parts that, while labeled as "Alto Trombone", are generally considered to be mislabeled tenor trombone parts. This list is by no means exhaustive or definitive, and more extensive research on this matter would be prudent. Of course, as Sluchin points out:

-it is very important to inform the conductor, who might never have heard of an alto trombone. ${ }^{158}$

Ultimately, the performer's responsibility to select an historically accurate trombone, is usurped only by the responsibility of a loyal instrumentalist to relinquish matters of instrumentation to the discretion of the maestro.

${ }^{158}$ Sluchin, “Alto or Tenor Trombone: Open or Closed Case?.", p. 309. 
Table 1

Orchestral Notational Variations that include Alto Trombone and/or Alto Clef

$\begin{array}{llll}\text { Part Clef } & \text { Type of Trombone } & \text { Example composers }\end{array}$

\begin{tabular}{|c|c|c|c|}
\hline 1st & $\overline{\mathrm{A}}$ & Alto & \multirow{3}{*}{$\begin{array}{l}\text { Mozart, Haydn, Handel, } \\
\text { Beethoven, Mendelssohn, } \\
\text { Berlioz*, Brahms** }\end{array}$} \\
\hline 2nd & $\mathrm{T}$ & Tenor & \\
\hline 3rd & B & Bass & \\
\hline
\end{tabular}

\begin{tabular}{|l|l|l|l|}
\hline 1st & A & Tenor & $\begin{array}{l}\text { Bruckner (excluding } \\
\text { masses), Dvorak** }\end{array}$ \\
\cline { 1 - 3 } 2nd & T & Tenor & \\
\hline 3rd & B & Bass & \\
\hline
\end{tabular}

\begin{tabular}{|c|c|c|c|}
\hline 1st & $\mathrm{T}$ & Alto & \multirow{3}{*}{$\begin{array}{l}\text { Schubert (in score only), } \\
\text { Berg (specifying alto for } \\
\text { 1st part) }\end{array}$} \\
\hline 2nd & $\mathrm{T}$ & Tenor & \\
\hline 3rd & B & Bass & \\
\hline
\end{tabular}

\begin{tabular}{|l|l|l|l|}
\hline 1st & A & Alto & Schumann (in score only) \\
\hline 2nd & A & Tenor & \\
\hline 3rd & B & Bass & \\
\hline
\end{tabular}

\begin{tabular}{|c|c|c|c|}
\hline $1 \mathrm{st}$ & $\mathrm{A}$ & Tenor & Rimsky-Korsakov, $^{* *}$ \\
\hline 2nd & A & Tenor & Prokofiev, Shostakovich, \\
\hline $3 \mathrm{rd}$ & $\mathrm{B}$ & Bass & Stravinsky, Dvorak** \\
\hline
\end{tabular}

*Contemporary practice finds the tenor trombone better suited for section balance and dynamic range. After 1835, Berlioz wrote for tenor trombone and also implied that his earlier works should also perform the First Trombone parts on tenor. Not all works by this composer use this system of notation and/or trombone complement.

${ }^{* *}$ Not all works by this composer use this system of notation. 


\section{CHAPTER II}

\section{ALTO TROMBONE PEDAGOGY}

In order to explore the viability of the transposing alto trombone method, it is prerequisite to objectively summarize past and present alto trombone pedagogical resources, and to outline the transposing method as set forth in published alto trombone method books. Pedagogical materials for the alto trombone have been reviewed by several sources. Most recently, an article appearing in the International Trombone Association Journal by Will Kimball and Joseph Hansen provides an overview of "the 11 commercially available pedagogical books specifically written for alto trombone." ${ }^{1}$ Kimball and Hansen give a succinct description of alto trombone method books by the following authors: Stephen Anderson (2 volumes), Roger Harvey, Robert Mullen, Karsten Parow, Branimir Slokar, Benny Sluchin (4 volumes). Kimball and Hansen also describe The Professional's Handbook of Orchestral Excerpts: Alto Trombone by Ken Shifrin. ${ }^{2}$ Although Shifrin's work is not a method book, Kimball and Hansen include it "because of its pedagogical usefulness for the alto trombone student."3 Adding to the list begun by Kimball and Hansen, the following authors have written alto trombone method books also commercially available: Jozef Gasparovic (Slovene/German/English), Klaus Winkler (German), Ursel Schardinel (German), Gudrun Mau (German), Jérôme Naulais (French), and Astrid Nøkleby (Norwegian/English). Another alto trombone method book is the culmination of a doctoral essay by Franklin Jaeckle. ${ }^{4}$ Although not currently for sale, Jaeckle's method is available through Inter-Library Loan from the University of Iowa.

\footnotetext{
1 Will Kimball and Joseph Hansen, "Alto Trombone Pedagogical Materials." ITA Journal 35 (January 2007): pp. 44-46.

${ }^{2}$ Ken Shifrin, The Orchestral Excerpt Series for the Orchestral "Doubler": The Professional's Handbook of Orchestral Excerpts, Alto Trombone (West Midlands, England: Virgo Music Publishers, 1986).

${ }^{3}$ Kimball and Hansen, "Alto Trombone Pedagogical Materials.", p. 45.

${ }^{4}$ Franklin Jaeckle. A Comprehensive Performance Project in Trombone Literature with an Essay consisting of a Method Book for the E-flat Alto Trombone. (DMA Essay, University of Iowa, 1982).
} 
Succinct annotations concerning alto trombone pedagogical materials have been provided by Robert Kehle. ${ }^{5}$ In-depth descriptions of alto trombone pedagogical materials have been provided in doctoral research projects by Lawrence Mitchell (1987), David Mathie (1993), David Johansen (1993), and Douglas Warner (2005). Each dissertation gives specific and detailed information describing the philosophy, methodology, range, and types of exercises found in the method books listed:

Lawrence Mitchell. A Comprehensive Performance Project in Trombone Literature With an Essay Consisting of Performance Editions of Selected Intermediate Level Solos Transcribed and Edited for E-Flat Alto Trombone and Piano. University of Iowa (1987).

1. Anderson, A Complete Method for Eb Alto Trombone.

2. Parow, Initiation Complete Au Trombone Alto.

David Mathie. The Alto Trombone: Twentieth-Century Performance Practices and Pedagogy in the United States. University of Georgia (1993).

1. Anderson, A Complete Method for Eb Alto Trombone.

2. George Maxted, Twenty Studies for Tenor Trombone.

3. Parow, Initiation Complete Au Trombone Alto.

4. Slokar, Method for Alto Trombone.

David Johansen. An Essay Consisting of an Examination of Alto Trombone Use in Metropolitan and Regional Symphony Orchestras in the United States and of Pedagogical Materials and Curricula Currently Available for that Instrument. University of Iowa (1993).

1. Anderson, A Complete Method for Eb Alto Trombone.

2. Jaeckle, A Comprehensive Performance Project in Trombone

\footnotetext{
${ }^{5}$ Robert Kehle, Alto Trombone Literature: An Annotated Guide, $2^{\text {nd }}$ edition (Coventry, England: Warwick Music Limited, 2005), pp. 7-12.
} 
Literature with an Essay consisting of a Method Book for

the Eb-Alto Trombone.

3. Mullen, 32 Etudes for Alto Trombone.

4. Parow, Initiation Complete Au Trombone Alto.

5. Shifrin, The Professional's Handbook of Orchestral Excerpts:

Alto Trombone.

6. Slokar, Method for Alto Trombone.

Douglas Warner. Current Trends in Alto Trombone Pedagogy in the United States. University of Cincinnati, College-Conservatory of Music (2005).

1. Anderson, A Complete Method for Eb Alto Trombone.

2. Harvey, Brass work Book for Alto Trombone.

3. Parow, Initiation Complete Au Trombone Alto.

4. Slokar, Method for Alto Trombone.

5. Sluchin, Study Material for the Alto Trombone.

It should be noted that, according to Kimball and Hansen ${ }^{6}$, many teachers prefer to dive into the literature not using a particular method book at all, but rather start immediately with solo or orchestral repertoire. That the alto trombone is quickly becoming a part of formal trombone education is evidenced in Warner's survey results. While Mathie found that $87 \%$ of respondents in his survey were "self-taught" alto trombonists ${ }^{7}$, the later study by Warner found that slightly more than half (50.8\%) of his respondents had received some formal training on the alto. ${ }^{8}$ It would be a misinterpretation of data to assume that formal training on alto trombone necessitates the use of an alto specific method book. Nonetheless, the proliferation of new pedagogical materials points to the likelihood of some increase in method book use. ${ }^{9}$

${ }^{6}$ Kimball and Hansen, "Alto Trombone Pedagogical Materials.", p. 44.

7 David Mathie, The Alto Trombone: Twentieth-Century Performance Practices and Pedagogy in the United States (DMA Document, University of Georgia, 1993), p. 114.

8 Douglas Warner, Current Trends in Alto Trombone Pedagogy in the United States (DMA Document, University of Cincinnati, College-Conservatory of Music, 2005), p. 15.

${ }^{9}$ Kimball and Hansen, "Alto Trombone Pedagogical Materials.", p. 44. 
The purpose of this chapter is: 1) to specifically categorize pedagogical alto trombone books according to methodology, 2) provide objective descriptions of available alto trombone method books not covered elsewhere in the literature, and 3) to list and discuss how available pedagogical materials utilize or relate to the transposing method of alto trombone.

\section{CATEGORIES OF METHOD BOOKS}

1. Historical (c1793-1906)

Many of the original alto trombone method books discussed hereafter come from didactic materials of the late $18^{\text {th }}$ and early $19^{\text {th }}$ centuries. The earliest example of an alto trombone method book can be traced back to André Braun's Gamme et Méthode pour Les Trombonnes Alto, Ténor, et Basse (circa 1793 or 1797). ${ }^{10}$ Braun's method was intended to be used in conjunction with François René Gebauer's 50 Leçons pour La Trombonne Basse, Alto, \& Tenor (circa 1795 or 1797) ${ }^{11}$ and thereby offer more than a mere theoretical treatise. Used together, these two sources established the prototype for the modern trombone method book by: 1) providing a detailed practical guide to performing on trombone, and 2) providing progressive supplemental exercises as a means of achieving precise pedagogical goals. ${ }^{12}$ Aside from the Braun and Gebauer, only three of the more than forty known $19^{\text {th }}$-century trombone method books specifically indicate the alto in the title: ${ }^{13}$

Sturm. Méthode Complette pour les Trombonnes Basse, Tenor, et Alto. Paris: Philippe Petit (c. 1816-1826) [no extant copies].

\footnotetext{
${ }^{10}$ see Howard Weiner, “André Braun's Gamme et Méthode pour les Trombonnes: The Earliest Modern Trombone Method Rediscovered." Historic Brass Society Journal 5 (1993): p. 288-308.

${ }^{11}$ see Howard Weiner, "François René Gebauer's 50 Leçons pour La Trombonne Basse, Alto, \& Tenor: The Earliest Book of Études for the Trombone." Historic Brass Society Journal 11 (1999): pp. 107-112.

12 Herbert, The Trombone, p. 138.

${ }^{13}$ Herbert, The Trombone, Appendix 3, pp. 327-330.
} 
Cornette, Victor. Méthode du Trombone Alto, Tenor, et Basse. Paris: Richault (c. 1842).

Wirth, A. Posaunen-Schule für Alt, Tenor, und Bass Posaune ...Instruction Book of the Simple and Valve Trombone. London: Augener \& Co. (1870).

Cornette's Méthode du Trombone Alto, Tenor, et Basse was a revised version of his earlier Méthode du Trombone (1831) expanded to include specific exercises, scales and etudes for the alto trombone. ${ }^{14}$ Of course, some early documents, for example Fröhlich's Vollständige theoretisch-pracktische Musikschule (1811), ${ }^{15}$ include alto trombone instruction even though no direct mention of the alto appeared in the title. In addition to the previously mentioned Braun/Gebrauer, and Cornette, the following historical method books have been included in Kehle's annotated list ${ }^{16}$ as containing specific, albeit minimal, alto trombone instruction:

Nemetz, Andreas. Newest Trombone Method. Vienna: Anton Diabelli and Company. (1827).

Seidel, Edward. Practical School for the Slide Trombone, Part 2. New York: Carl Fischer. (1906).

Historical alto trombone methods have been written in the traditional concert-pitched alto clef. However, clef alone is not a reliable means of determining instrument variety. For example, Nemetz's Method described the alto as being pitched in Bb leading Howard Weiner to contend that no part of this book was truly written for alto trombone. Weiner cites evidence from Nemetz's time-period that

\footnotetext{
${ }^{14}$ Benny Sluchin and Raymond Lapie, "Slide Trombone Teaching and Method Books in France (17941960)." Historic Brass Society Journal 9 (1997): pp. 9-10.

15 reprinted in David Guion, The Trombone: Its History and Music 1697-1811 (New York: Gordon and Breach, 1988), pp. 94-117.

${ }^{16}$ see Kehle, Alto Trombone Literature: An Annotated Guide, $2^{\text {nd }}$ ed., pp. 11-12.
} 
confirms the distinction between the alto and the tenor trombone as one classified not by different fundamental pitches but merely by different mouthpiece sizes. ${ }^{17} \mathrm{~A}$ more thorough inspection of archival didactic materials would likely disinter additional minute alto trombone pedagogical references and tenor trombone alto clef exercises. However, none of the preceding historical methods have been seriously recommended as a practical means to aid the present-day trombonist in learning the alto trombone, primarily due to the brevity of exercises and specific instruction contained in these method books. ${ }^{18}$ Therefore, even a painstaking inspection of all period trombone-related resources is unlikely to yield further useful information about alto trombone pedagogy from this time-frame.

\section{Current (1950 to present)}

Published in 1950, Robert Miller's School for Trombone, Book III contained a brief series of etudes and duets specifically labeled "Also for the Alto-Trombone in $\mathrm{Eb}^{\prime \prime},{ }^{19}$ thus marking the first appearance of idiomatic alto-trombone-specific instructional material in nearly half a century. Miller's School included an alto trombone position chart and has been recommended by Kehle for use as "supplemental material for alto study." 20 Although further alto clef study material was intermittently published, the alto trombone was apparently not given specific coverage in trombone method books published during the 1960s and 1970s. The alto trombone was referenced in prevalent trombone texts such as Reginald Fink's The Trombonist's Handbook (1970), Denis Wick's Trombone Technique (1971), and Robin Gregory's The Trombone (1973), but it was Klaus Winkler's Method for Alto Trombone (1980) that marked the first contemporary method book designed exclusively for the alto instrument.

\footnotetext{
17 Howard Weiner, "Andreas Nemetz's Neueste Posaun-Schule: An Early Viennese Trombone Method." Historic Brass Society Journal 7 (1995): p. 15.

${ }^{18}$ Kehle, Alto Trombone Literature: An Annotated Guide, $2^{\text {nd }}$ ed., pp. 11-12.

${ }^{19}$ Robert Miller, School for Trombone, Book III (New York: Spratt Music Publishers, 1950), p. 48.

${ }^{20}$ Kehle, Alto Trombone Literature: An Annotated Guide, $2^{\text {nd }}$ ed., p. 12.
} 


\section{a) For Proficient Tenor Trombonists}

Current (in-print) methods exclusive to the alto trombone can be divided into two categories. First, there is the continuation of the historic norm-alto trombone as a secondary instrument intended for already proficient tenor trombonists. Method books in this category are specifically designed for alto trombone pedagogy and typically include: a discussion of methodology, alto trombone position charts, preliminary exercises such as scales or lip slurs, progressive etudes, and/or orchestral excerpts. The following alto trombone method books fall into this category (in chronological order):

1. Winkler, Method for Alto Trombone (1980).

2. Parow, Initiation Complete Au Trombone Alto (1982).

3. Jaeckle, A Comprehensive Performance Project in Trombone Literature with an Essay consisting of a Method Book for the Eb-Alto Trombone (1982).

4. Slokar, Method for Alto Trombone (1983).

5. Mullen, 32 Etudes for Alto Trombone (1984).

6. Anderson, A Complete Method for Eb Alto Trombone. 2 vols. (1984-86).

7. Naulais, Etudes 20 Variées sur la Virtuosité \#14 (1995).

8. Harvey, BrassWorkBook for Alto Trombone (1998).

9. Sluchin, Study Material for the Alto Trombone. 4 vols. (1998-2002).

10. Gasparovic, Alto Trombone-Work with Instrument (2000).

All of the above listed books are commercially available with the exception of the Jaeckle. It should be noted that the majority of alto trombone method books designed for already proficient tenor trombonists are written entirely in concertpitch alto clef. In addition to exercises in concert-pitch alto clef, the following methods include study material in alternative clefs: Anderson (transposed bass); Winkler (non-transposed bass, and concert-pitch treble); Mullen (transposed treble-horn in F parts); and Harvey (concert-pitch tenor, concert-pitch treble, and non-transposed bass). In the category of alto trombone methods designed for tenor 
trombonists, only Anderson's method offers transposition as a comprehensive approach to the instrument.

\section{b) For Young Beginners}

Secondly, there is a more recent category of alto trombone pedagogy that is designed for beginning trombonists. The idea of having a young beginner play alto was first explored in the 1940 s as a way to make the trombone more ergonomically appropriate for young children who were physically unable to reach all of the trombone positions. ${ }^{21}$ This category is divided into two camps, 1 ) beginning alto pedagogy using concert pitch, and 2) beginning alto pedagogy using transposition. The latter approach is designed to better facilitate the switch from alto to tenor trombone when the student is physically able. Alto trombone method books for young beginners include (in chronological order):

1. Schardinel, Alto Trombone Method for Children (1998).

2. Nøkleby, On To The Music (2000).

3. Mau, Alto Trombone Method: Exercises and Songs around the First Sounds (2005).

Nøkleby employs transposition (bass clef, and in Bb treble); Schardinel and Mau do not. Schardinel's Method is available in concert-pitch in three separate editions of either bass, alto, or treble clef. Mau's Method is written exclusively in nontransposed bass clef.

\section{Alto Clef Studies (c1930 to present)}

Mathie found that the next most popular alto trombone pedagogy book (after Anderson) was George Maxted's Twenty Studies for Tenor Trombone. ${ }^{22}$ Maxted's volume, obviously intended for tenor, is technically not an alto trombone method

\footnotetext{
${ }^{21}$ Traugott Rohner, "Introducing the F Alto Trombone." The Instrumentalist 18 (1949-1950): p. 18.

22 Mathie, The Alto Trombone..., p. 88.
} 
book because it does not provide pedagogical instruction for the alto trombone. Twenty Studies is used for alto study because it exploits the trombone's upper register and is written exclusively in alto clef. ${ }^{23}$ Given the popularity of this type of book for alto trombone study, the current study has included an additional category of alto trombone pedagogical materials designated as Alto Clef Studies. Although not specific to instrument selection, the following studies (in chronological order) are conceivably applicable to alto trombone due to their inclusion of large sections of alto clef exercises:

1. Blazhevich, School for Trombone in Clefs, Section III (c1930/2008).

2. Kahila, Advanced Studies in Tenor and Alto Clefs (1948).

3. Lafosse, School of Sight Reading and Style, Book E (1949).

4. Fink, Introducing the Alto Clef (1969).

5. Sauer, Clef Studies (1977).

6. Uber, First Studies in Alto Clef (1986).

7. Maxted, Twenty Studies for Tenor Trombone (1991).

8. Edwards, Introductory Studies in Tenor and Alto Clef (2002).

9. Jørgensen, 24 Improvisations (no date)-out of print.

Kehle provides annotations for the preceding clef studies books, excepting Blazhevich's School for Trombone in Clefs, Lafosse's School of Sight Reading and Style, and Sauer's Clef Studies. Kehle discusses the range, content, and feasibility for use with alto trombone for each reviewed book. He selects the Jørgensen, Kahila, and Maxted as the most appropriate for supplemental alto trombone material, with the Fink and Uber books qualifying as adequate, secondary choices. ${ }^{24}$

Blazhevich's original 1939 School for Trombone in Clefs (and subsequent editions thereof) was intended for tenor trombone and consisted of two parts, "Section I. Fundamentals of Trombone Playing" and "Section II. Exercises in All

\footnotetext{
${ }^{23}$ Ibid.

${ }^{24}$ Kehle, Alto Trombone Literature: An Annotated Guide, $2^{\text {nd }}$ ed., pp. 11-12.
} 
Seven Positions." Kehle's Annotated Guide likely omits Blazhevich's method because its use of alto clef is irregular and usually in short spurts. However, a recent edition of Blazhevich's School for Trombone in Clefs by Andrey Kharlamov and Michael Deryugin ${ }^{25}$ includes previously unavailable material in alto clef that is labeled as "Section III. Alto Trombone Studies." Unfortunately, neither the editorial remarks by Kharlamov nor the annotations provided by Ward Stare in this edition offer any historical background or organological insight as to the inclusion of these alto clef exercises as part of the School for Trombone. While the majority of the exercises in Kharlamov's Section III are exclusively in alto clef, 11 of the 41 exercises extend below the possible low range of the standard alto trombone. ${ }^{26}$ Unlike Section I of Blazhevich's School for Trombone, which includes a tenor trombone position chart and other introductory material, the "Alto Trombone Studies" section includes only exercises and no pedagogical information. As these "Alto Trombone Studies" were previously unavailable in the United States, it is inconclusive whether or not Blazhevich explicitly arranged this order of exercises as an independent section. Some of the studies were presumably taken from Blazhevich's unpublished 50 Etudes for Alto Trombone, of which only 25 etudes were extant as of 2005.27

Due to problems with range and a lack of instructional material, it is also unclear whether or not Blazhevich actually intended all of the etudes in Kharlamov's Section III for the alto trombone. Adding to the uncertainty, a 1985 Russian edition of Blazhevich's School for Trombone integrated several of these previously unavailable alto clef exercises into Section I of the book with no mention of the alto trombone. ${ }^{28}$ Blazhevich was not known to have ever performed on the alto

\footnotetext{
${ }^{25}$ Blazhevich, Vladislav. School for Trombone in Clefs including the All New Alto Studies, $2^{\text {nd }}$ edition, ed. by Andrey Kharlamov and Michael Deryugin, annot. by Ward Stare. First published in 1939. Chicago and Moscow: East-West Music International, Inc., 2008.

${ }^{26}$ It is probably safe to assume that Blazhevich did not intend the low range of his exercises to be accommodated by an $\mathrm{Eb}$ alto trombone fitted a Bb valve, as the valve attachment mechanism was not generally available on the alto until the 1980s. See Christian Lindberg's "Why a Bb Attachment on the Alto Trombone?" ITA Journal 19 (Summer 1991): p. 26.

${ }^{27}$ Andrey Kharlamov, Vladislav Blazhevich: A History of His Life, Career, and Compositions (DM Document, Northwestern University, 2005), p. 107.

${ }^{28}$ From personal communication with Dr. J. Mark Thompson, March 1, 2010, author of a forthcoming
} 
trombone during his career as a professional trombonist, ${ }^{29}$ although according to Kharlamov, Blazhevich did recommend that his students study the alto as a means of preparing for orchestral auditions. ${ }^{30}$ Unfortunately, Kharlamov offers no evidence to support his premise that these exercises were specific to the alto instrument. To compare Blazhevich's work to the next generation of clef study books, Kauko Kahila's Advanced Studies In Tenor and Alto Clefs (1948) devoted half of its etudes to alto clef, but was designed for the tenor trombone; several of Kahila's alto clef etudes also extend below the possible low range of the alto trombone. Regardless of his intended instrumentation, Blazhevich's exercises in Kharlamov's "Alto Trombone Studies" makes a satisfactory choice for work with alto trombone, providing that one can circumvent the out-of-range low notes through octave transposition or use of a $\mathrm{Bb}$ valve. The 41 exercises explore the full range of the alto, from $\mathrm{BBb}$ to $\mathrm{f} 2$, and are well-crafted and challenging.

Although not cited by Kehle, Lafosse's School of Sight Reading and Style and Sauer's Clef Studies constitute additional possibilities for supplemental alto trombone work. The fifth book of five (Book E) in Lafosse's sight-reading series contains ten etudes in alto clef, ten etudes in alto and tenor clef, and ten etudes in alto, tenor, and bass clef. Lafosse described the book as "extremely difficult" 31 and as the book was intended for tenor trombone, many of the exercises extend down to $\mathrm{E}$, below the possible low range of the alto. A more practical choice for use with alto trombone might be Sauer's Clef Studies. Sauer included 18 intermediate alto clef exercises (alternating with tenor exercises) that cover a range from $B$ to $\mathrm{b}^{1}$, with an emphasis on the "unfamiliar" yet "melodically simple." 32 Table 2 lists all the previously discussed pedagogical materials according to methodology and focus.

ITA Journal review of the Kharlamov/Deryugin edition of Blazhevich's School for Trombone. ${ }^{29}$ André Smith, "Vladislav Mikhailovich Blazhevich (1886-1942): Some Recollections on the Semicentennial of His Death." ITA Journal 21 (Winter 1993): p. 23.

${ }^{30}$ Kharlamov, Vladislav Blazhevich: A History of His Life, Career, and Compositions, p. 81.

${ }^{31}$ Lafosse, School of Sight Reading and Style, Book E, p. 2.

32 Ralph Sauer, Clef Studies for Trombone (Century City, CA: Wimbledon Music, 1977), p. 2. 
Table 2

Categorization of Alto Trombone Method Books

\begin{tabular}{|c|c|c|c|}
\hline \multirow{2}{*}{$\begin{array}{l}\text { Category of } \\
\text { Method Book }\end{array}$} & \multicolumn{2}{|c|}{ Concert-Pitch } & \multirow[t]{2}{*}{ Transposing } \\
\hline & Alto clef & Other & \\
\hline $\begin{array}{l}\text { Alto trombone for } \\
\text { proficient tenor } \\
\text { trombonists }\end{array}$ & $\begin{array}{l}\text { Anderson } \\
\text { Harvey } \\
\text { Winkler } \\
\text { Parow } \\
\text { Slokar } \\
\text { Sluchin } \\
\text { Naulais } \\
\text { Gasparovic } \\
\text { Mullen } \\
\text { Jaeckle* }\end{array}$ & $\begin{array}{l}\text { Harvey } \\
\text { Winkler }\end{array}$ & $\begin{array}{l}\text { Anderson } \\
\text { Mullen (F horn) }\end{array}$ \\
\hline
\end{tabular}

\begin{tabular}{|c|c|}
\hline $\begin{array}{l}\text { Alto clef studies (not } \\
\text { specific to alto } \\
\text { trombone) }\end{array}$ & $\begin{array}{l}\text { Blazhevich } \\
\text { Fink } \\
\text { Sauer } \\
\text { Edwards } \\
\text { Uber } \\
\text { Maxted } \\
\text { Kahila } \\
\text { Jørgensen** } \\
\text { Lafosse }\end{array}$ \\
\hline
\end{tabular}

\begin{tabular}{|l|l|l|l|}
\hline $\begin{array}{l}\text { Alto trombone } \\
\text { for beginners }\end{array}$ & Schardinel & $\begin{array}{l}\text { Schardinel } \\
\text { Mau }\end{array}$ & \\
& & & Nøkleby \\
\hline
\end{tabular}

*Not commercially available

**Out of print 


\section{OBJECTIVE DESCRIPTIONS OF UNREVIEWED ALTO TROMBONE METHOD BOOKS}

At the outset, a distinction must be established between alto trombone methods and alto trombone study material. An alto trombone method book has been defined as simply a pedagogical book "specifically written for the alto trombone." 33 However, alto clef studies, as described previously, do not provide instruction specific to the alto trombone, and in many cases were intended for the tenor trombone. Additionally, collections of alto trombone orchestral excerpts, such as Shifrin's Professional Handbook, are not classified as alto trombone methods because they do not include pedagogical instruction for learning the alto. The alto trombone study material found in Blazhevich's 50 Etudes for Alto Trombone ${ }^{34}$ represents a category of alto trombone specific etude book has recently resurfaced. Frank Darmiento has compiled a collection of etudes intended for and idiomatic to the Eb alto that does not incorporate an alto trombone method per se. ${ }^{35}$ By excluding instructional information, this category of alto trombone etude book presupposes the alto trombonist's ability to play the instrument. Similarly, David Schwartz has arranged a collection of Bordogni vocalises designed to be played on Eb alto. ${ }^{36} \mathrm{He}$ includes a series of warm-up slurs specific to the alto, and a CD of synthesized accompaniments to "help improve intonation very quickly." 37 Like Darmiento, Schwartz does not provide an alto trombone method, but in this case does acknowledge the secondary nature of the alto trombone. The Bordogni etudes in Schwartz's volume are transcribed a perfect fourth higher than standard so that tenor trombonists will "find the slide position movement patterns familiar and comfortable" on alto. ${ }^{38}$ Schwartz's edition for alto trombone is in alto clef;

\footnotetext{
${ }^{33}$ Kimball and Hansen, "Alto Trombone Pedagogical Materials.", p. 44.

${ }^{34}$ Although Blazhevich's 50 Etudes for Alto Trombone (c1930) remain unpublished, this is one of the likely sources of the alto clef exercises found in Kharlamov's 2008 edition of the Blazhevich School for Trombone in Clefs. See previous section.

35 Frank Darmiento, Alto Trombone Etudes (Scottsdale, AZ: Sackbut Music, 2006).

36 David Schwartz, The Bordogni Vocalises, vol. 1: Solo part for Alto Trombone, transcribed from Marco Bordogni's 24 Nouvelles Vocalises à la portée de toutes les voix [no date] (Belmont, MA: David A. Schwartz, 2007).

${ }^{37}$ Ibid., p. ii.

38 Ibid.
} 
otherwise, engaging the muscle memory of familiar slide positions while playing Bordogni etudes on the alto trombone could be accomplished by playing at a transposition from any bass clef Bordogni edition (sounding up a perfect fourth). A review of Schwartz's editions can be found in the Online Trombone Journal. ${ }^{39}$ Despite an obvious relevance as supplemental material for a practical course of alto trombone study, alto clef studies, orchestral excerpt collections, and alto trombone etude books are either not specific to trombone choice, or do not offer more than rudimentary didactic material concerning alto trombone. Therefore, these types of alto trombone study material cannot be included in a discussion of alto trombone pedagogy that endeavors to compare instructional methodologies. Additional information regarding the use of alto clef studies and orchestral excerpt collections as alto trombone study material has been provided by Kehle. 40

Several commercially available method books dedicated to alto trombone pedagogy have not been formally reviewed in the literature. This section of the current study endeavors to supplement Kimball and Hansen's article ${ }^{41}$ by offering comparable succinct descriptions of alto trombone method books by: Gasparovic, Winkler, Jaeckle, Schardinel, Mau, and Nøkleby. Naulais's volume for alto was omitted from Kimball and Hansen's inventory but has been comparably reviewed in the ITA Journal by Kevin Chiarizzio. ${ }^{42}$ Several of the materials included in Kimball and Hansen's article have also been reviewed independently in the ITA Journal; a list of these reviews comprises Appendix D of the current study (for quick reference, see Table 3). Although Jaeckle's method has been discussed at length by Johansen, ${ }^{43}$

\footnotetext{
${ }^{39}$ Kedrik Merwin, "The Bordogni Vocalises by David Schwartz: A Review." Online Trombone Journal, 2010. Available at <http://www.trombone.org/articles/library/viewarticles.asp?ArtID= 197>, accessed March 1, 2010.

${ }^{40}$ Kehle, Alto Trombone Literature: An Annotated Guide, $2^{\text {nd }}$ ed., pp. 11-12.

${ }^{41}$ Kimball and Hansen, "Alto Trombone Pedagogical Materials."

${ }^{42}$ Kevin Chiarizzio, "Jérome Naulais: 20 Etudes Variées sur la virtuosité, le style et le rhythme for alto trombone. Paris: Gérard Billaudot Éditeur, 1995. Grade 5-6." Review in ITA Journal 33/4 (October 2005): pp. 81-82.

${ }^{43}$ David Johansen, An Essay Consisting of an Examination of Alto Trombone Use in Metropolitan and Regional Symphony Orchestras in the United States and of Pedagogical Materials and Curricula Currently Available for that Instrument (DMA Essay, University of Iowa, 1993), pp. 54-56.
} 
and Nøkleby has been the focus of two articles in the ITA Journal, ${ }^{44}$ both are also included in this section for consistency with the more concise overview format established by Kimball and Hansen. Similarly, Mau's Method will be included here as it has thus far been reviewed only in German. ${ }^{45}$ Reviews of alto trombone method books provided by the current study are divided into two categories: methods for proficient tenor trombone players, and methods for young beginners.

${ }^{44}$ Lee Hill Kavanaugh. "Babes in Slideland: Preschool Trombone students in Scandinavia." ITA Journal 24 (Fall 1996): pp. 38-45; and Astrid Nøkleby. "Tots on Trombone." ITA Journal 27 (Summer 1999): pp. 20-21.

${ }^{45}$ see Albert Steinhauser's review published in SONIC magazine, available through Mau's Alto Trombone Method website, <www.altoposaunenschule.de/>. 
Table 3

Quick Reference for Reviews of Alto Trombone Pedagogical Materials

\begin{tabular}{|l|l|l|l|l|l|}
\hline AUTHOR & \multicolumn{1}{|c|}{$\begin{array}{c}\text { ABBREVIATED } \\
\text { TITLE }\end{array}$} & $\begin{array}{c}\text { DATE } \\
\text { OF } \\
\text { PUBL. }\end{array}$ & $\begin{array}{r}\text { ITA } \\
\text { JOURNAL } \\
\text { REVIEW }\end{array}$ & \multicolumn{1}{|c|}{ DATE OF } & \multicolumn{1}{|c|}{ REVIEWER } \\
\hline Anderson & Complete Method & 1984 & $12 / 2$ & April 1984 & R. Lumpkin \\
\hline Blazhevich & New Alto Clef Studies & 2008 & $38 / 2 ?$ & forthcoming & J. M. Thompson \\
\hline Edwards & Introductory Studies & 2002 & $32 / 2$ & April 2004 & P. Overly \\
\hline Harvey & BrassWorkBook & 1998 & $28 / 4$ & Fall 2000 & W. Kimball \\
\hline Kehle & Annotated Guide & 1998 & $28 / 2$ & Spring 2000 & W. Kimball \\
\hline Naulais & 20 Etudes & 1988 & $33 / 4$ & Oct. 2005 & K. Chiarizzio \\
\hline Maxted & 20 Studies & 1954 & $22 / 4$ & Fall 1994 & J. Mead \\
\hline Mullen & 32 Etudes & 1984 & $15 / 4$ & Fall 1987 & J. Elias \\
\hline Parow & Initiation Comp. & 1982 & $14 / 4$ & Fall 1986 & J. Elias \\
\hline Shifrin & Profess. Handbook & 1987 & $15 / 4$ & Fall 1987 & J. Marcellus \\
\hline Uber & First Studies & 1989 & $17 / 1$ & Winter 1989 & R. Babcock \\
\hline Uber & Symphonic Studies & 1992 & $23 / 4$ & Fall 1995 & B. Stanley \\
\hline
\end{tabular}

For Proficient Tenor Trombonists:

Gasparovic, Jozef. Alto Trombone-Work with Instrument. Bratislava, Slovakia: Príloha, 2000. 80 pp. [Slovene, German, and English text].

The preface to this work discusses the switch from tenor to alto, and the importance of a routine and "-personal commitment to the activity of practice." After a few charts describing alto trombone positions and various clefs, this book launches into beginning exercises that gradually explore the available notes of consecutive alto positions. After these starting exercises, the book continues with 100 progressive 
melodic exercises that include simple Slovakian folk melodies and melodies of classical composers. The book concludes with orchestral excerpts of well-known works including: Mozart's Requiem, Beethoven's Missa Solemnis, and Schumann Symphony No. 3. Certain excerpts also include the second and third trombone parts to facilitate section work emphasizing "orientation in harmony, intonation, rhythm, and voice-leading."

\section{Winkler, Klaus. Method for Alto Trombone: For Instruments Pitched in F and Eb. Munich, Germany: Bund Christlicher Posaunenchöre Deutschlands, 1980.94 pp. [German text].}

In the introduction of this text, Winkler describes the two alto trombone camps that his book addresses-in the brass choir, alto trombone is pitched in $\mathrm{F}$ and notated in treble and bass clef; in the symphony orchestra, the alto is in Eb and in alto clef. After some discussion on tone production and articulation, Winkler outlines each alto position with simple exercises clearly identified for either F or Eb alto. Duets for teacher and student are included early in the course of lessons to help with intonation. Curiously, although roughly half of Winkler's exercises are dedicated to the alto trombone in $\mathrm{Eb}$ (for orchestral use), alto clef is not introduced until nearly the end of the book, presumably after the student is already very comfortable reading alto trombone pitches in bass and treble clef.

\section{Jaeckle, Franklin. A Comprehensive Performance Project in Trombone Literature with an Essay consisting of a Method Book for the E-flat Alto Trombone. DMA Essay, University of Iowa, 1982.}

According to Johansen, "Frank Jaeckle's method was written for the advanced tenor trombone student who wishes to use the alto trombone as a supplementary instrument." 46 As such, Jaeckle provides practical information such as selecting an alto trombone to purchase, and how to avoid the inherent intonation

\footnotetext{
${ }^{46}$ Johansen, An Essay Consisting of an Examination of Alto Trombone Use..., p. 54.
} 
pitfalls of the alto. Jaeckle includes 44 technical and melodic exercises that are graded according to difficulty and represent all major and minor keys. The last section of the book discusses the history of alto trombone in the orchestra and includes 12 standard alto trombone excerpts such as: Beethoven's Symphony No. 5, and Symphony No. 9; Mozart's Requiem; and Schumann's Symphony No. 3.

\section{For Beginning Trombonists:}

\section{Schardinel, Ursel. Alto Trombone Method for Children. Seboldhausen, Germany: Musikschulbedarf \& Buchversand, 1998. 64 pp. [German text].}

Schardinel's Method is a well-organized instructional guide designed for beginning music students around age seven or eight. Schardinel includes a discussion of trombone maintenance and daily objectives, as well as a discussion of tone production broken down into five physical components: the diaphragm, lungs, throat, tongue, and the lips. The book gradually introduces notes for the alto trombone one at a time starting with $\mathrm{Bb}$ and $\mathrm{Eb}$, followed by some basic musical concepts such as articulation styles and dynamics. The exercises in the book are progressively arranged adding more notes and complex rhythms within the context of simple tunes. Alto Trombone Method for Children was originally written in alto clef, but now includes editions in concert-pitch treble clef (8vb) and bass clef allowing more options for parents wishing to purchase supplemental music for their beginner alto trombonists. For example, Schardinel suggests that the treble clef (8vb) edition offers students the opportunity to play music for $\mathrm{C}$ trumpet, recorder, or voice. The student is expected at some point to make a one-time switch to tenor trombone. After relearning the familiar alto notes on tenor trombone, the student is given new notes in bass clef; Schardinel permits a two to three week period for the student to transition from alto to tenor. ${ }^{47}$

\footnotetext{
${ }^{47}$ from personal communication with Ursel Schardinel, June 6, 2009.
} 


\section{Mau, Gudrun. Alto Trombone Method: Exercises and Songs around the First Sounds. Kißlegg, Germany: Musikverlag Gudrun Mau, 2005. 238 pp. [German text].}

Since 1982, Gundrun Mau has been teaching young students on the alto trombone. This book recommends starting students of the appropriate physical and mental maturity (around the age of nine) in group or individual lessons. Mau gives a very detailed account of beginning alto trombone and all aspects of early music education including: body posture, handling the instrument, breathing, instrument maintenance, and tone production. The book includes simple drawings to illustrate creative solutions to some of the common problems occurring with younger students. The book also provides blank staff lines to motivate children to create their own melodies using the notes they have acquired on trombone. Teachers are then encouraged to create countermelodies to be played as a duet. Mau's Method gradually introduces the student to simple folk melodies, hymns, and Christmas music, and is written exclusively in non-transposed bass clef.

\section{Nøkleby, Astrid. On To The Music: An Introduction in} English. Norway: Warner/Chappell, 2000.

The On To The Music series consists of three separate books: a general guide to teaching, piano accompaniment, and exercises for parent and pupil with CD. Nøkleby's method, drawing inspiration from the well-known Suzuki method for violin and ideas from the Norwegian Band Association, prescribes an early start and a positive learning environment. Nøkleby suggests that young children are ready to learn instrumental music but are constrained by the physical limitations of the instruments. Using smaller scale instruments such as the pocket trumpet, tenor horn, and alto trombone, Nøkleby's method is designed for small children as young as age four or five. The alto trombone exercises are written at a transposition-sounding a perfect fourth higher than written-on two separate lines, one in bass clef and the other as a Bb treble clef part. In this way, the trombone 
student learns to read notes that are visually consistent with music for the eventual switch to tenor trombone.

\section{THE TRANSPOSING METHOD}

This section will outline the framework of the transposing approach to alto trombone as formalized in published alto trombone method books. Of primary importance to this study is Stephen Anderson's Complete Method as it carefully defines the transposing method of playing alto trombone and dedicates half of its musical exercises to this approach. Anderson's Method provides identical exercises in both conventional concert-pitch alto clef notation and in transposed bass clef notation. In the Introduction to this book, Anderson acknowledges that transposing is unfamiliar to most trombonists, and he emphasizes starting on the correct pitch (partial). He also acknowledges that the obvious drawback to learning this method is that most of the available literature is not available in transposed bass clef. Anderson establishes three separate techniques in his book that are intended to allow the trombonist "to choose any one method, any combination, or to do them all." 48 Conjoined with the implicit yet consequential obligation of alto clef literacy, Anderson advises that, "The greatest obstacle to overcome in using [traditional alto clef notation] is that you must relearn the positions for all the notes." 49 A trombonist selecting the transposing method might find it "easier and more readily successful" 50 given the inherent setbacks of the traditional alto clef method.

Anderson is quoted in Mathie's study responding to a questionnaire regarding alto trombone pedagogy:

After memorizing solos, this respondent found he really hadn't learned the notes and positions; it was a rote process. After hearing an alto trombone

\footnotetext{
${ }^{48}$ Stephen Anderson, A Complete Method for Eb Alto Trombone, vol. 1 (Denton, TX: Modern Editions, 1984), p. i.

${ }^{49}$ Ibid., p. ii.

${ }^{50}$ Ibid., p. iii.
} 
presentation in which the clinician mentioned thinking about the notes and positions a fourth lower-thus allowing a more comfortable "feel"-this process was formalized into one of the three methods discussed mentioned in his method book. 51

The clinician Anderson quotes is Tom Ervin, a trombonist noted for playing jazz improvisation on the alto trombone. ${ }^{52}$ Ervin described his start on alto trombone as transferring tenor trombone jazz "licks" to the smaller instrument, before ever considering the advantage the transposing approach held for written music. ${ }^{53}$ The basic structural points of the transposing method conceptualized by Ervin and inaugurated by Anderson can be paraphrased as follows:

1) The alto trombonist plays a transposed part. In other words, the alto trombone part sounds a different pitch than is written.

2) Eb alto trombone parts are written in bass clef and transposed a perfect fourth below concert-pitch.

3) The Eb alto trombone is played as if playing a Bb tenor trombone, based on the Bb harmonic series and accordant slide positions.

4) Using the familiar $\mathrm{Bb}$ tenor slide positions, the transposed alto parts will sound at concert-pitch, a perfect fourth higher than written.

The other method of transposition systematized by Anderson involves the same process of transposition but uses clef visualization and interval transposition so as to avoid rewriting parts a fourth lower in bass clef. Anderson's second method of transposition is potentially awkward to trombonists; the procedure of interval

\footnotetext{
${ }^{51}$ Mathie, The Alto Trombone. ., p. 164.

52 from personal communication with Stephen Anderson, June 26, 2009.

53 from personal communication with Tom Ervin, July 3, 2009.
} 
transposition is more commonly utilized by hornists and/or trumpet players. ${ }^{54}$ Mathie's survey found that of the 165 respondents who played alto trombone, none employed this method of transposition. ${ }^{55}$ Further details of Anderson's Method have been described in the Mitchell, Mathie, Johansen, and Warner dissertations, as well as in the Kimball and Hansen article mentioned previously. The commentary of these documents regarding transposition and Anderson's Method will be addressed in the following chapter of the current study.

Benny Sluchin's Study Material for Alto Trombone is the only other alto method for proficient tenor trombonists that mentions the transposing alto trombone approach. Curiously, Sluchin does not endorse the transposing method as a practical alternative to more traditional practices but offers no satisfactory answers as to why this method should be avoided. ${ }^{56}$ Slokar's Method does not specifically mention the transposing method but admonishes against being tempted to "-apply by analogy the exercises meant for tenor trombone to the alto trombone ... if played a fourth higher all the way through, would have a harmful effect on the strength of the lips." 57 Similarly, Parow cautions that playing tenor trombone exercises on alto (sounding a perfect fourth higher) could lead to "overtaxing oneself in higher pitches." 58 Although specific tenor trombone exercises are not identified, Slokar and Parow are presumably counseling against playing in the upper register of the alto before the proper embouchure strength has been developed.

Method books designed for beginner alto trombonists who are not yet tenor players are unusual if compared to the historic norm for alto trombone pedagogy. Bearing in mind that the alto trombone has always been secondary to the tenor trombone, students that begin on alto will be forced to cope with the inevitable

\footnotetext{
${ }^{54}$ Anderson, $A$ Complete Method for Eb Alto Trombone, vol. 1, p. ii.

55 Mathie, The Alto Trombone..., pp. 86-87.

${ }^{56}$ See Chapter III of the current study for epexegesis.

${ }^{57}$ Branimir Slokar, Methode Complete de Trombone Alto, vol. 1( Zumikon, Switzerland: Editions Marc Reift, 1983), p. 4

${ }^{58}$ Karsten Parow, Initiation Complete au Trombone Alto, ed. Gerard Billaudot (Paris: Gerard Billaudot, 1982), p. 4.
} 
switch to tenor at some point regardless of notation. First-time trombonists beginning on alto and reading concert-pitch alto clef parts (as found in Schardinel) suggests an exaggerated potential for older trombonists to perform on alto, or a non-existent need for alto trombonists that play alto exclusively. Due to the difference in fundamental pitch, Eb alto trombone beginners reading concert-pitch parts in any clef would be required to relearn the slide positions when the eventual switch to $\mathrm{Bb}$ tenor trombone is enacted. Previously, the use of alto trombone for beginners playing concert-pitch parts was outlined in Gloria Flor's article in Woodwind, Brass, and Percussion. 59 The inherent value of starting trombonists on alto notwithstanding, an alternative approach using transposition has also been established. Astrid Nøkleby starts her trombone students on alto trombone using transposed parts to facilitate the switch to tenor trombone when the student is physically able. Nøkleby's method offers transposition in two concurrent formats (see Example 3):

1) Bass clef transposed down a perfect fourth from concert-pitch in a manner identical to Anderson's application.

2) Treble clef transposed up a major sixth from concert-pitch. This approach is used in conjunction with the British brass band tradition of treble clef trombone parts in $\mathrm{Bb}$ (sounding a major ninth lower than written) and is intended for brass band pupils. When parts are read on Eb alto as if playing a transposed $\mathrm{Bb}$ tenor trombone part, concert-pitch is achieved.

The concept of starting trombonists on transposed alto was previously explored by Traugott Rohner in his article printed in The Instrumentalist. ${ }^{60}$ He suggested using an alto trombone pitched in $\mathrm{F}$ to accommodate the short arms of younger students and offered three methods of transposition based on which brass instrument the

${ }^{59}$ Gloria Flor, "The Alto Trombone as a Beginner's Instrument." Woodwind, Brass, and Percussion 22 (September 1983): p. 13.

${ }^{60}$ Traugott Rohner, “Introducing the F Alto Trombone." The Instrumentalist 18 (1949-1950): p. 18. 
student was intending to switch to from the $\mathrm{F}$ alto. Rohner's procedures of transposition did not achieve widespread acceptance in part due to the obsolescence of the $\mathrm{F}$ alto trombone.

Example 3-Nøkleby's Use of Transposition

The two lines above the piano part are for alto trombone. The top line is for brass band pupils (sounds a major sixth lower than written); the next line is for students that will switch to tenor trombone using standard bass clef notation (sounds a perfect fourth higher than written). In this example, the soprano line in the piano part sounds exactly one octave higher than the concert-pitch of both alto trombone lines.

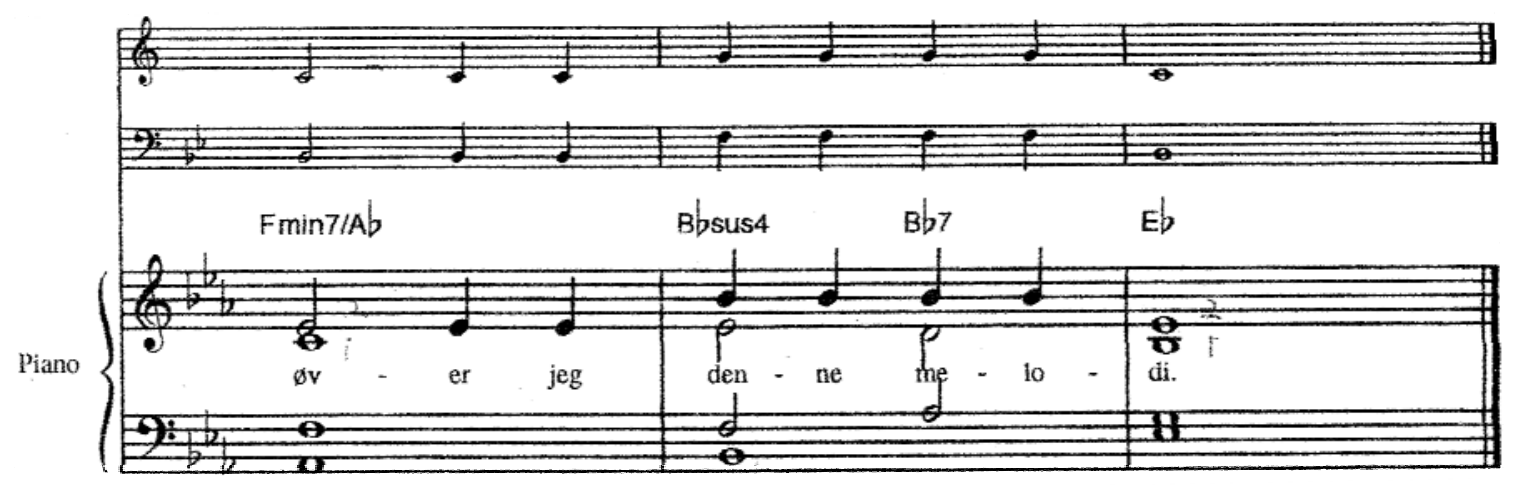

CNorsk Musikforlag A/S, Oslo, 2000. Used with permission. 


\section{CHAPTER III \\ EVALUATING THE TRANSPOSING METHOD}

The method of employing transposition for secondary instruments is now widespread and successful with the majority of wind instruments excepting low brass. ${ }^{219}$ For trombonists, the transition from the primary (tenor) to the secondary (alto) instrument presents both fixed challenges due to the proportional size differences of the tenor and alto, and complications that are dependent upon the trombonist's choice of notation. Obstacles due to the physical construct of the alto are inevitable regardless of methodology: 1) the shorter slide/intonation, 2) higher tessitura/endurance, 3) differences in air resistance, and 4) differences in response. ${ }^{220}$ The additional challenges of reading written music are as follows:

If transposing: 5) no longer playing at concert pitch, and 6) rewriting literature as necessary.

If reading concert-pitch alto clef: 5) having a command of alto clef, 6) relearning all the correct positions for written notes, 7) relearning the appropriate notes for use of alternate positions, and 8) familiarity with the inherent intonation tendencies of a harmonic series constructed on Eb instead of Bb.

Chapter I of the current study substantiates that nearly all varieties of the trombone have been historically classified and notated as concert-pitch instruments. However, there have been a few intermittent points in history when trombones have breached the confines of non-transposition for specific applications. The current study will outline the historical circumstances surrounding the trombone as a transposing instrument to determine if, by comparison, the transposing approach

\footnotetext{
${ }^{219}$ Kennan and Grantham, The Technique of Orchestration, pp. 386-388.

${ }^{220}$ Sluchin, Study Material for the Alto Trombone, vol. 1, pp. 18-19.
} 
to the alto trombone has substance as a relevant and permanent notational advancement.

Several modern sources concur that the transposing approach to alto trombone is initially more effective. ${ }^{221}$ However, many of these same sources reject the transposing method as a long-term solution to the challenges of playing alto trombone. It seems that even an impartial acknowledgment of the success of the transposing method must invariably be followed by a caveat, as illustrated by the following quote from Kimball and Hansen (italics added):

Anderson's two-volume method book provides the simplest means for reading on alto trombone, a method of transposition that essentially eliminates the initial learning of new positions on the instrument, although some trombonists feel that this method may create eventual difficulties that are not worth the shorter learning curve. ${ }^{222}$

The current study will dissect the body of commentary concerning the transposing method as found in specific trombone books, periodicals, and dissertations in order to ascertain the merit of the argument against transposition. In order to evaluate the inherent advantages of the transposing method, relevant alto trombone pedagogical sources that exclude transposition have been similarly scrutinized. The purpose of this chapter is: 1) to provide evidence that the use of transposition for secondary trombones has some historical precedent, 2) to propose that the transposing method for alto trombone is therefore logical based on this historical precedent, and 3) to defend the transposing method as a viable alternative to traditional notation by rebutting published and printed observations devoted solely to the conventional concert-pitch alto clef approach to the alto trombone.

\footnotetext{
${ }^{221}$ Ibid., p.18, and Kimball and Hansen, “Alto Trombone Pedagogical Materials.", p. 46, for example. 222 Kimball and Hansen, p. 46.
} 


\section{HISTORICAL PRECEDENT OF TROMBONE TRANSPOSITION}

Secondary trombones have on rare occasion been envisaged as transposing instruments. Praetorius' recommended method of transposition for the quint trombone, as discussed in Chapter I, was perhaps the first formal suggestion of trombone transposition, although not the only implication that trombone transposition was in practice during the late Renaissance. Baines describes German tenor trombones of the late $16^{\text {th }}$ century that included crooks to change the fundamental of the instrument. In addition to crooks being used simply to extend the trombone's low range, some crooked trombones were exclusively designated as transposing instruments. Baines describes one such trombone:

Secund, a tone lower that ordinary, should signify a trombone on which you played an $a$ and it came out $g$ and so on. 223

Baines also mentions that along the same lines, some German instrument makers created trombones with built-in (non-removable) crooks. The resulting "secundposaune" and "terz-posaune" trombones were listed in German instrument inventories alongside ordinary trombones available with crooks. In performance, these trombones were likely paired with cornettos that already customarily employed larger-sized instruments when transposing music down. Using Secund instruments, a cornetto/trombone ensemble could play written music a whole step lower than indicated "without the player having to change the fingering [or slide position] for the written notes. ${ }^{224}$

Another historical example of trombone transposition can be found in Berlioz' Treatise on Instrumentation. Berlioz described an "alto trombone with valves" pitched in either F or Eb.225 The alto valve trombone was undoubtedly a

\footnotetext{
${ }^{223}$ Anthony Baines, Brass Instruments: Their History and Development (New York: Charles Scribner's Sons, 1978), p. 117.

224 Ibid., p. 116.

225 Berlioz and Strauss, A Treatise on Modern Instrumentation and Orchestration, p. 330.
} 
secondary instrument in Berlioz's time given the scant coverage it receives in the Treatise. Berlioz provided few clues as to the valved alto trombone's specific applications stating only that the instrument was used for solo melodies. Berlioz's clear preference for the slide trombone at the time could indicate the poor quality of valved alto instruments or performers available to him, or merely Berlioz's documented admiration of the (slide) trombonist Antoine Dieppo. ${ }^{226}$ More intriguing, however, is Berlioz' description of the valved alto as a transposing instrument. Berlioz lists the alto trombone with valves as written either in alto or treble clef and sounding a perfect fifth lower than written (alto in F), or a major sixth lower than written (alto in Eb), identical to the transposition system for trumpet or cornet.

Example 4-Berlioz's Illustration of Transposition for the Valved Alto Trombone
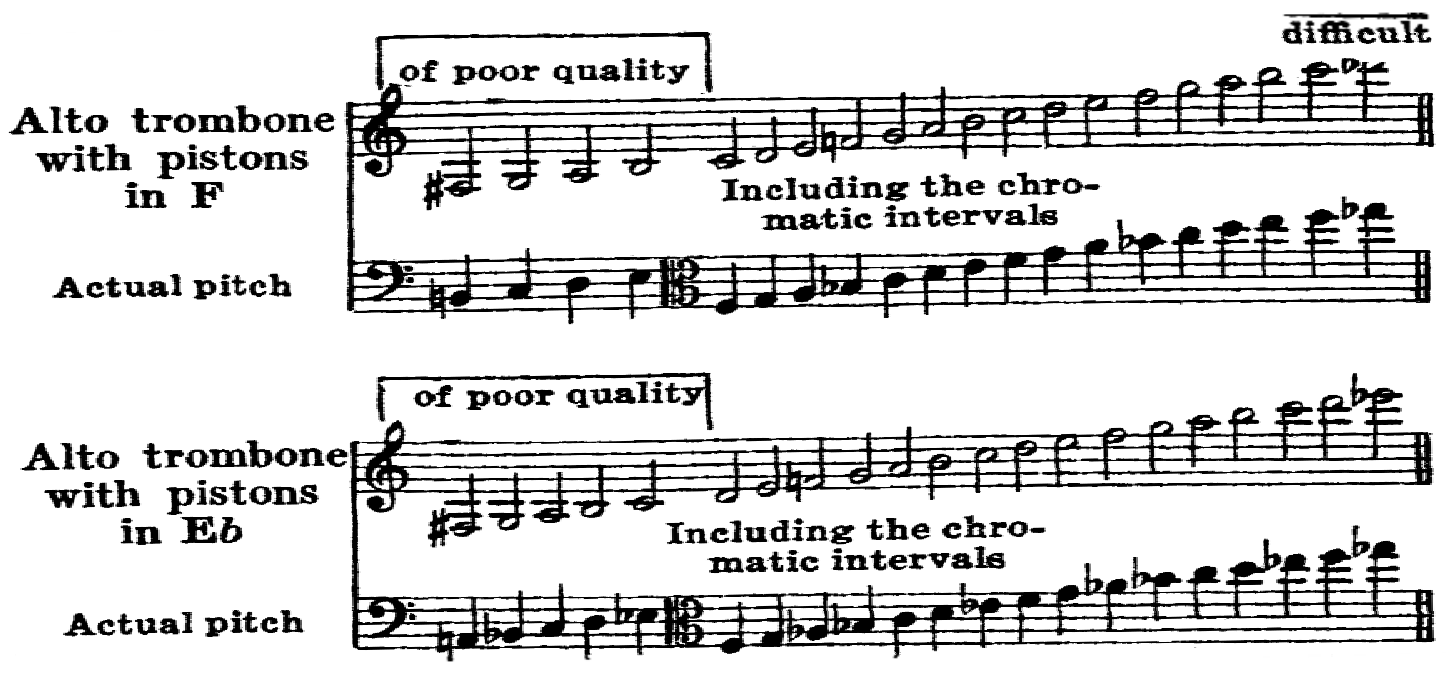

Berlioz remarked that the valved alto was "in certain respects a cornet with pistons in $\mathrm{Eb}$ or $\mathrm{F}$ with a somewhat stronger tone."227 Berlioz omitted an explanation of the performers on this instrument, although it is apparent that the valved alto was notated like a cornet because it was intended to be played by cornetists rather than trombonists. This notion is supported by a collection of quartets published the

${ }^{226}$ Berlioz wrote highly of Dieppo in his Treatise and elsewhere, and even attended a few of Dieppo's trombone classes at the Paris Conservatory. See Herbert, The Trombone, pp. 130-136.

${ }^{227}$ Berlioz and Strauss, A Treatise on Modern Instrumentation and Orchestration, p. 330. 
trombonists. This notion is supported by a collection of quartets published the same year as Berlioz's Treatise. Kresser's 12 Quatuors pour quatre Cornets a pistons (1844) is scored for four cornets, with an option to play the lowest part on Eb alto valve trombone. ${ }^{228}$ Better evidence that the valved alto was usually played by cornetists comes from the well-known tenor trombone solo of Berlioz's Grande Symphonie Funèbre et Triomphale. The Oraison Funèbre solo was published with an alternate part for the alto valve trombone, ${ }^{229}$ and in 1848 , when Berlioz conducted the Grande Symphonie in London, the extensive trombone solo in the second movement was performed on the valved alto by the eminent German cornet player Hermann Koenig. 230

In addition to being conceived of as transposing instruments, what links Praetorius' quint trombone, the Secund-and Terz-posaune of the late Renaissance, and Berlioz's alto valve trombone is that these trombones were all secondary instruments. The mere designation of different-sized trombones as quint, terz, and secund attests to a trombone hierarchy and the progenitorial nature of the (ordinary) tenor trombone; for valved alto, notational practice of the day suggests performers whose primary instrument was the cornet. In each of these cases transposition was offered as a practical method of making the secondary instrument more accessible, and in each of these cases the system of transposition was regrettably extinguished with the obsolescence of the instrument itself. A more recent application of trombone transposition became manifest with the French $\mathrm{Db}$ alto trombone in the first half of the $20^{\text {th }}$ century. Although the precise origin of the $\mathrm{Db}$ alto trombone is elusive, the method of transposition used in conjunction with this instrument indicates that the $\mathrm{Db}$ alto may have been designed to ease the reintroduction of the alto trombone in France during a time when top trombone parts were traditionally performed on tenor trombone.

\footnotetext{
${ }^{228}$ Will Kimball, "Alto Trombone Timeline." Will Kimball, Trombone [online].

${ }^{229}$ Herbert, The Trombone, p. 191.

${ }^{230}$ Hugh Macdonald, Berlioz's Orchestration Treatise: A Translation and Commentary (Cambridge: Cambridge University Press, 2002), p. 229.
} 
In 1925, French trombonist Gaston Flandrin described the new model of $\mathrm{Db}$ alto trombone as having resulted from previous flaws in the construction of the alto instrument:

The decline of the alto trombone was also brought about by the mediocre quality of sound it made; object of trials to perfect it, it was constructed, in turn, pitched in F, $\mathrm{E}$, and $\mathrm{Db}$, without appreciable results, because the general structure of the instrument alone was at fault; it was finally endowed with a special semi-cylindrical bore, of which the application is summed up in the establishment of a smaller tube than the other, with a longer slide, and the addition of a bell more suited to the instrument; it appears today as elegant, sonorous, and with good timbre, ready to reclaim its place relying on the support of its numerous enthusiasts. Useless to reproduce the old types, all the same proportions have been kept; the new model is established in $\mathrm{Db}$ which gives it a personal and precious sonority. ${ }^{231}$

Additional clues as to the origin of the $\mathrm{Db}$ alto trombone are somewhat limited. Sluchin referred to the $\mathrm{Db}$ alto trombone as "an intermediate instrument" but does not elaborate on his claim that the instrument was "used in France in the 19th century." 232 More prominent 19 $9^{\text {th }}$-century French instrumentation treatises, such as those authored by Berlioz [1844], and François Gevaert [1885] ${ }^{233}$ report only the Eb alto slide trombone, and the earliest fixed dates associated with the $\mathrm{Db}$ alto trombone are from the beginning of the $20^{\text {th }}$ century . Lafosse documented the use of the $\mathrm{Db}$ alto at a 1909 concert in which this instrument joined a trombone sextet comprised of six different sizes of trombone. ${ }^{234}$ Flandrin's Méthode Complète de Trombone á Coulisse Ténor [1910] further outlined the function of Db alto trombones, ${ }^{235}$ and a reference to the "modern" Db alto trombone in Charles

\footnotetext{
231 Gaston Flandrin, "Le Trombone." in Encyclopédia de la Musique et Dictionnaire du Conservatoire, Deuxième Partie: Technique-Esthétique-Pédagogie, ed. Albert Lavignac (Paris: Librarie Delagrave, 1925), pp. 1655-1656. This translation by Thomas Carr.

232 Benny Sluchin, Study Material for the Alto Trombone, vol. 1, p. 11.

${ }^{233}$ François Gevaert, Nouveau Traité D'Instrumentation (Paris and Brussels: Lemoine et Fils Éditeurs, 1885), p. 241.

${ }^{234}$ André Lafosse, Traité de Pédagogie du Trombone á Coulisse (Paris: Alphonse Leduc, 1955), p. 12.

235 Gaston Flandrin, Méthode Complète de Trombone á Coulisse Ténor, vol. 1 (First published in Paris:
} 
Koechlin's orchestration treatise in $1954^{236}$ suggests that this instrument was used in France throughout the first half of the $20^{\text {th }}$ century. Lafosse still considered $\mathrm{Db}$ alto trombones to be the standard in France at the publication of his Treatise on Teaching the Slide Trombone in $1955 .{ }^{237}$

In France, the alto trombone in Db was treated as a transposing instrument. By means of clef visualization, a Db alto trombonist could use standard tenor trombone positions when reading alto trombone parts written in traditional concert-pitch alto clef. Flandrin described this method of transposition ...

The alto trombone being constructed to sound (with equivalent positions) a minor third above the tenor trombone, the tenor trombonists called upon occasionally to use the alto trombone, so as not to change the mechanism [slide technique], transpose the written part a minor third lower. 238

... and included a notated demonstration in his Méthode Complète (see Example 5). Lafosse similarly described the use of clef visualization/transposition for the $\mathrm{Db}$ alto trombone. By adding three sharps to the key signature and reading concert-pitch alto clef parts as if in tenor clef, $\mathrm{Db}$ alto trombonists could achieve the best of both worlds-preserving the same slide positions between tenor and alto trombones while still reading from existing alto trombone parts. Lafosse explained, from a historic vantage, the problem of concert-pitch notation and transitioning between trombones:

The result of this is that the two instruments, while identical in the relation of the positions to their own fundamentals, were unable, at the time, to be used by the

Adolph Dubois, 1910. Reprint, Paris: E. Gaudet, 1923), p. 6.

${ }^{236}$ Charles Koechlin, Traité de L'Orchestration, vol. 1. (Paris: Éditions Max Eschig, 1954), p. 93.

237 Lafosse, Traité de Pédagogie du Trombone á Coulisse, pp. 10-12.

238 Gaston Flandrin, Méthode Complète de Trombone á Coulisse Ténor, vol. 1, p. 6. This translation by Thomas Carr. 
same trombonists, i.e., the tenor trombonists could not apply their technique to the alto, and vice versa. ${ }^{239}$

Although Lafosse's chronicle implies the somewhat debatable existence of specialist alto-only trombonists, the challenge he described in transitioning between alto and tenor instruments is the same problem faced by contemporary trombonists. Unfortunately, current practice does not find this method of transposition readily available for alto trombonists due to the obscurity of the Db alto trombone. Perhaps owing to the revival and subsequent popularity of the alto in $\mathrm{Eb}$, the $\mathrm{Db}$ alto trombone was unlikely to have achieved absolute dominance even in France. ${ }^{240}$

Example 5-Method of Transposition for the Db Alto Trombone

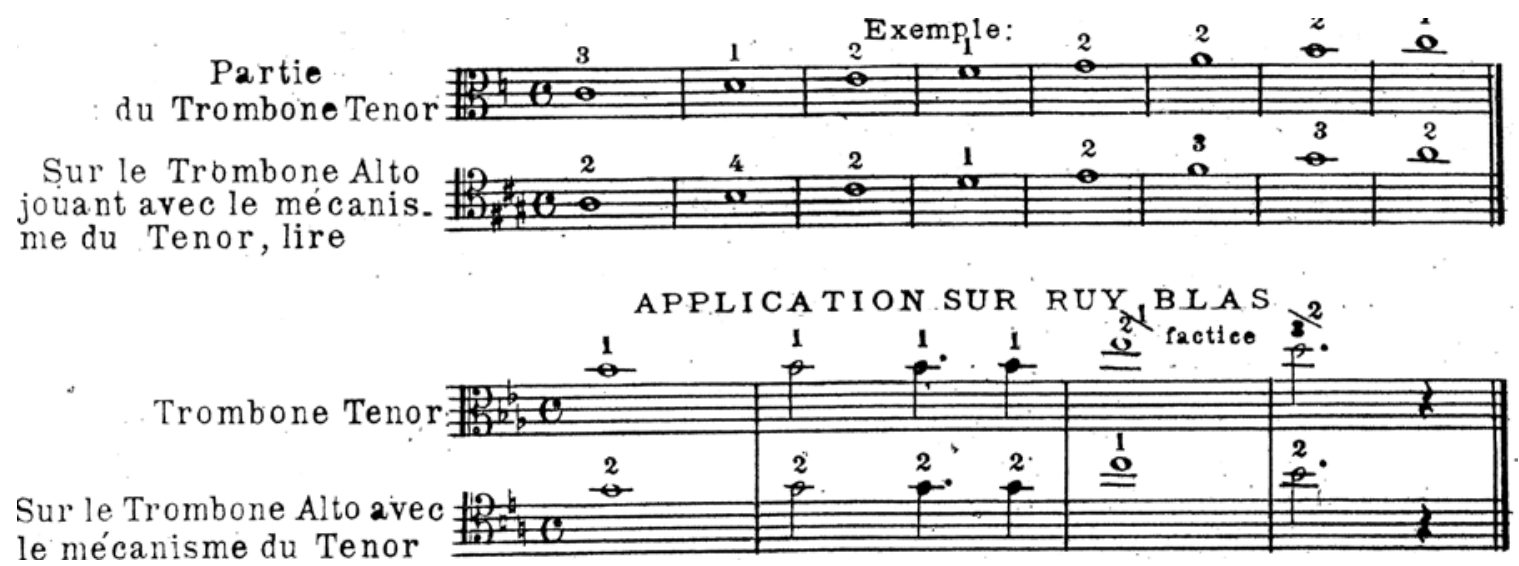

A discussion of transposing trombones would be remiss to omit the one area where the trombone continues as a transposing instrument-in the conventions of British brass band writing. In traditional brass band notation, the trombone is written in treble clef as a Bb instrument, sounding a major ninth lower than written. ${ }^{241}$ The all-brass band became popular in Britain as early as the 1830s, and by the 1870s the competitive circuit for brass bands was in full swing. ${ }^{242}$ At the end

239 Lafosse, Traité de Pédagogie du Trombone á Coulisse, p. 12.

${ }^{240}$ Ken Shifrin, "The Alto Trombone in the Orchestra 1800-2000." British Trombone Society [online], Appendix 2.

${ }^{241}$ Baines and Myers, "Trombone, §1: Slide trombone." Grove Music Online.

${ }^{242}$ Arnold Myers, "Instruments and Instrumentation of British Brass Bands" in The British Brass 
of the $19^{\text {th }}$ century, brass bands had largely adopted standardizing measures that, along with the authoritative influence of some of Britain's leading conductors of the time, created a "common idiom" that defined the Brass Band as a movement. ${ }^{243}$ Herbert and Wallace explain (italics added):

The most crystallizing factor as regards to the movement towards uniformity must have been the standardization of instrumentation which was very similar to the instrumentation of the twentieth century brass band by 1890 . Also evident by this time was the practice, which was to endure, of writing all but one of the parts [bass trombone] in the treble clef. This idiosyncrasy was intended to be pragmatic and didactic. $^{244}$

Transposition was gradually ushered into the brass band genre following the advent of the saxhorn family of instruments (patented in 1845). ${ }^{245}$ Adolphe Sax, among other $19^{\text {th }}$-century instrument makers, emphasized the ease of teaching a family of instruments by maintaining uniform fingerings and reading, given that the instruments differed in size but not in character. ${ }^{246}$ In addition to the advantage of brass band musicians being able to swap and/or double on instruments, the system of clef and transposition conformity provided a "range-conducive" staff assignment that avoided an excess of ledger lines for all brass instruments. Tenor trombonists, already accustomed to avoiding ledger lines through the use of alto and tenor clef, might have resisted the brass band's treble-clef standardization if not for a visual coincidence-the fact that $\mathrm{Bb}$ treble clef parts and concert-pitch tenor clef parts produce an identical note placement on the staff. Transposed Bb tenor trombone parts can be interpreted by tenor-clef reading trombonists using clef visualization

Band: A Musical and Social History, ed. Trevor Herbert (London: Oxford University Press, 2000): p. 174.

243 Trevor Herbert and John Wallace. "Aspects of Performance Practices: The Brass Band and its Influence on other Brass-Playing Styles." in The British Brass Band: A Musical and Social History, ed. Trevor Herbert (London: Oxford University Press, 2000): p. 288.

244 Ibid., p. 287.

${ }^{245}$ Scott Whitener, A Complete Guide to Brass, $3^{\text {rd }}$ ed. (Belmont, CA: Thomson Schirmer, 2007), p. 132. 246 Wally Horwood, "Transposition—-the logical approach." Crescendo International 10 (January 1972), p.39. 
(reading the treble clef as tenor) and adjusting the key signature (adding 2 flats or subtracting 2 sharps). ${ }^{247}$

Example 6-Clef Visualization for Bb Treble Clef Parts

$\mathrm{Bb}$ Treble clef (written)

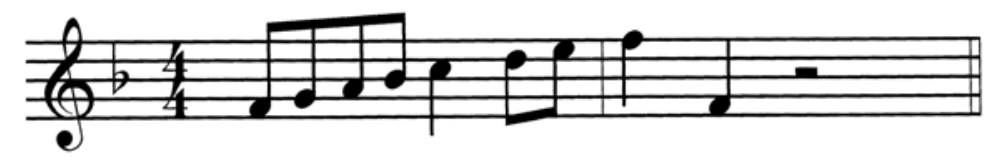

Tenor clef visualization (sounding)



Although both $\mathrm{Eb}$ and $\mathrm{F}$ alto trombones were used in the early stages of the brass band movement, the alto trombone never achieved permanent status in brass band instrumentation. Mirroring its decline of use in the symphony orchestra, the alto trombone would have been atypical in a brass band after the 1860 s. $^{248}$ The allbrass wind band selected against the alto trombone due to the more robust tone of the alto horn, and the greater volume output of the tenor and bass trombones. ${ }^{249}$ Conjecturally, had the alto trombone retained a presence in the brass band tradition, $\mathrm{Eb}$ alto trombone parts would have followed the notational format used for $\mathrm{Eb}$ cornet, $\mathrm{Eb}$ alto horn, and Eb Bass parts. In the standardized brass band system, instruments are notated in treble clef and transposed according to the instrument's fundamental (excepting bass trombone parts written in concert-pitch bass clef). If the alto trombone had been notated in accordance with these basic principles of brass band transposition, the alto would be notated in Eb sounding a major sixth lower than written. This system is currently found in Nøkleby's On To The Music series for beginning trombonists that will switch to tenor reading $\mathrm{Bb}$ treble clef parts in the brass band tradition (see Example 3 on p. 61 of the current study for

${ }^{247}$ Edwards' Introductory Studies presents a concise explanation of this technique, pp. 34-36.

248 Myers, "Instruments and Instrumentation of British Brass Bands", p. 156.

${ }^{249}$ Ibid., pp. 156-157. 
notated example).

Hypothetically, brass band parts for the Eb alto would also facilitate the switch from tenor to alto trombone for either tenor-clef reading trombonists (using clef visualization) or for trombonists that read only Bb treble-clef parts (see Example 7):

Example 7-A Notational Comparison of Tenor Clef, and Treble Clef in "Bb" and "Eb." A Treble clef Eb alto trombone part could be visualized as either a Bb Treble clef tenor trombone part or a Tenor clef trombone part to achieve concert pitch.

$1^{\text {st }}$ position

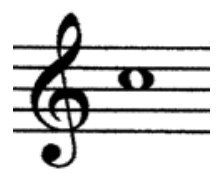

Eb written pitch... $1^{\text {st }}$ position

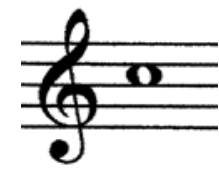

visualized as $1^{\text {st }}$ position

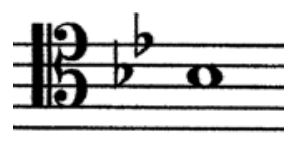

or tenor clef...

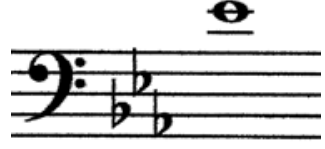

$=$ concert pitch

$\mathrm{Bb}$ treble...

Using this system of notation, a tenor trombonist switching to alto would maintain familiar slide positions and visual feedback in a manner similar to the transposing approach advanced by Anderson. In the existing brass band tradition, a comparable transition would occur if a $\mathrm{Bb}$ cornetist switched to playing (and reading parts for) the Eb cornet. If the alto trombone would have remained in the brass band tradition, a protocol might have been established for alto trombone parts to be written in Eb, making transposed alto parts more readily available; this manner of transposition would accommodate the alto trombone's secondary instrument status.

Based on the historical precedent for secondary trombones, it is logical for the current $\mathrm{Eb}$ alto trombone to be conceived of as a transposing instrument. The most impractical aspect of the transposing approach to alto trombone remains that 
transposed alto parts (via Anderson's transposed bass clef or the hypothetical brass band example in Eb treble clef) are unorthodox and comparatively rare. To this end, the current study offers a selection of common orchestral excerpts, appropriate for the alto trombone and rewritten in bass clef at a transposition (see Appendix E). A more complete list of orchestral excerpts appropriate for the alto trombone comprises Appendix B of the current study. A list of alto trombone solos that are available with transposed parts comprises Appendix C.

Further impetus for the application of transposition to the alto trombone could come from the revival of historic trombones with fundamentals other than $\mathrm{Eb}$. During the $18^{\text {th }}$-century, the Eb alto trombone was not universal; alto trombone parts in commonly performed works of this time-period were intended for either the $\mathrm{D}$ alto or $\mathrm{F}$ alto. Shigeki Saeki advocates that the expanding alto trombone movement recover the now obscure alto trombones pitched in D and F.250 Saeki suggests that in addition to being more historically accurate, trombonists might benefit from using an appropriately pitched alto trombone relative to the key of the music being performed. For example, Leopold Mozart's Trombone Concerto (extracted from Serenata in D for Orchestra ${ }^{251}$ ) is more idiomatic for the D alto trombone, while the $\mathrm{F}$ alto makes high range more manageable in Beethoven's symphonies. Using the current non-transposed notational practice, any performer choosing to heed Saeki's insights by performing on historic alto trombones would be forced to tackle additional new sets of slide positions and intonation tendencies based on each alto's different fundamental. For example, on a $\mathrm{D}$ alto trombone, the pitch " $\mathrm{d}$ " is found in $1^{\text {st }}$ position, $2^{\text {nd }}$ partial. Concert-pitch alto clef parts require $\mathrm{D}$ alto trombonists to relearn the slide placement for that note compared to the more familiar $4^{\text {th }}$ position (Bb tenor slide placement), or $2^{\text {nd }}$ position (Eb alto slide placement).

\footnotetext{
${ }^{250}$ Shigeki Saeki, “An Historical Perspective of the Alto Trombone.” Brass Bulletin 115 (2001): pp. 96101.

${ }^{251}$ see Herbert, The Trombone, pp. 115-116.
} 
Example 8-The Note "d" in Concert-Pitch Alto Clef for 3 Different Trombones
$4^{\text {th }}$ position
$1^{\text {st }}$ position
$2^{\text {nd }}$ position
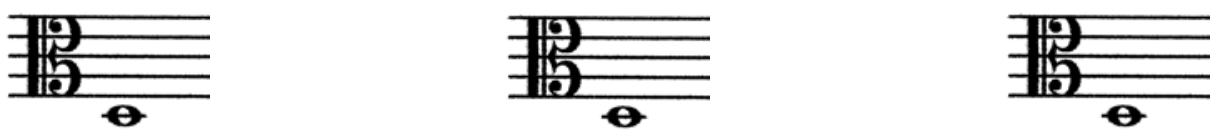
on $\mathrm{Bb}$ tenor
on D alto
on Eb alto

Assuming the $\mathrm{Bb}$ tenor trombone as a primary instrument, the process of selecting appropriate altos pitched in Eb, D, and F for specific applications would also burden a trombonist with four separate sets of slide positions with which to become familiar. While the financial burdens of owning separate altos could be reduced by using crooks, the notational burden of numerous distinct sets of slide positions is not unlike the historic scenario that prompted the first uses of transposition for brass instruments in the $17^{\text {th }}$ century. Although Saeki avoids commentary on notation, a simple transposition could circumvent the consternation of relearning slide positions for multiple instruments. The following example shows the use of transposition derived from primary $\mathrm{Bb}$ tenor trombone slide positions:

Example 9-The Note "d" with Transpositions for 2 Varieties of Alto Trombone (all examples sound concert-pitch "d" the same as Example 8)

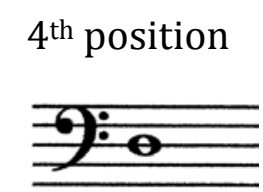

on $\mathrm{Bb}$ tenor

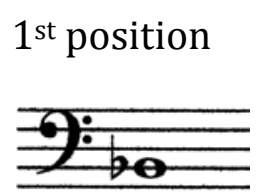

on D alto $2^{\text {nd }}$ position

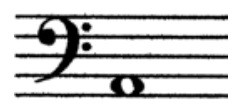

on Eb alto 


\section{PRINTED COMMENTARY AND ASSESSMENT}

This section will explore select quotes on the topic of alto trombone from published literature and research projects. This collection of quotes is by no means comprehensive but includes a representative sample of impartial descriptions and moderate support of, as well as scathing criticisms of, the transposing approach to alto as found in pedagogical books, periodical articles, and dissertations. Each quote will be followed by a brief annotation (from the vantage point of defending transposition) in order to assess the logic behind the words of the quote. Full citations for sources are supplied in the Bibliography of the current study.

\section{General Alto Trombone References}

The following quotes are from trombone pedagogical resources that are not necessarily exclusive to alto trombone but offer at least perfunctory mention of the instrument.

\section{Brad Edwards: Introductory Studies in Tenor and Alto Clef.}

There was a time when an orchestra section contained three completely different trombones-an alto, a tenor, and a bass. With the alto and sometimes the bass trombone, the slide positions were different than those of the tenor. Thus it made sense that each separate instrument would have its own clef. ${ }^{252}$

Edwards' opening commentary addresses the "why" of learning clefs on trombone. This quote has been included not to engage the validity of clef study, but rather to point out the tautological thinking that all too commonly finds its way into discussions of alto trombone notation. Edwards goes beyond merely explaining that different clefs exist for trombone. Rather, he weakly defends the use of alto clef for alto trombone citing the different slide positions of the alto and tenor. However, differences in slide positions hardly justify the use of different clefs as it is precisely

\footnotetext{
${ }^{252}$ Edwards, Introductory Studies, p. 2.
} 
because of concert-pitch alto clef for the alto trombone that the slide positions are different. This viewpoint assumes the inevitability of concert-pitch notation while failing to take into account the origins of alto trombone notation, the secondary nature of the alto trombone, and the system of transposition used by other brass instruments. The use of transposition allows the alto and the tenor to use the same clef and have the same positions (relative to slide length).

\section{Reginald Fink: The Trombonist's Handbook.}

Only half of the slide positions are the same as notes on tenor trombone on either instrument, so the slide technique of the alto in $\mathrm{E}$ flat is no easier to learn than the alto in $\mathrm{F}$. The alto trombone must be practiced regularly and the positions memorized as if beginning again if you are to be secure when performing on it. ${ }^{253}$

Fink's Trombonist's Handbook was first published in 1970, 14 years prior to Anderson's Complete Method. At that time, no alternative approach to standard concert-pitch alto clef notation for the Eb alto trombone had been formalized. If there were currently no alternative to playing alto trombone parts in anything other than concert-pitch alto clef then Fink's assertion of the necessity of "beginning again" would be undeniable. As it stands, the transposing method of playing alto allows a performer to transfer any gains of reading ability, mentally coupled with technique, as already secured by their experience on the tenor. In this way, the use of transposition circumvents "beginning again."

\section{Klaus Winkler: Method for Alto Trombone.}

In the brass choir, the alto trombone reads alternating between [concert-pitch] treble and bass clef. The alto clef, appropriate for the range of the instrument, is unknown in brass choir writing ...At the end of a special chapter, the alto clef is introduced. ${ }^{254}$

The exercises in Winkler's Method are primarily written in non-transposed bass clef.

\footnotetext{
253 Fink, The Trombonist's Handbook, p. 45.

254 Winkler, Schule für Altposaune, p. II. This translation by Dr. Ronald Horner.
} 
He uses almost the entire text to familiarize the student with air chambers and positions, before adding the extra dimension of reading alto clef. Because alto clef is largely disregarded, this book may have been originally designed for $\mathrm{F}$ alto trombone (German brass choir) and only later modified to include exercises for $\mathrm{Eb}$ alto trombone (orchestral). Nonetheless, barring the unlikely possibility that German brass choir alto trombonists in the 1980s were alto-only specialists, whether or not a notation is "known" in brass choir writing is irrelevant. Assuming the secondary status of the alto trombone (to the tenor trombone) in either a German brass choir or orchestral setting, transposition circumvents the necessity of the rudimentary material that Winkler so laboriously outlines. Within the framework of the concert-pitch alto trombone model, this method is thorough and valuable; merely replace any of the concert-pitched clefs with a rewritten transposed part and, for competent tenor trombonists, Winkler's efforts become redundant.

\section{Will Kimball. "Learning the Alto Trombone." Will Kimball, Trombone [online].}

One of the biggest initial obstacles in learning the alto trombone is simply learning to read music with a new set of positions. ${ }^{255}$

Transposition eliminates the need to learn a new set of positions, and in terms of a shorter learning curve for beginners, is undeniably the most logical and effective means to playing alto trombone.

\section{Specific to the Transposing Method}

Objective and impartial commentary concerning the transposing method of alto trombone is unusual. Warner provides a more matter-of-fact exception in his perspective on a shortcoming of the Anderson method:

255 Will Kimball, "Learning the Alto Trombone." Will Kimball, Trombone [online], 2010. Available at <http://www.kimballtrombone.com/alto-trombone/learning- the-altotrombone/>, accessed January 23, 2010. 


\section{Douglas Warner: Current Trends in Alto Trombone Pedagogy.}

Anderson's method for reading alto trombone music in pre-transposed bass clef never became widely-practiced, and very little of the growing alto trombone literature can be found in the transposed version required for this method. ${ }^{256}$

Warner does not engage the subject further in order to weigh the benefits or disadvantages of using transposition on alto trombone after the relatively simple task of rewriting music, but recommends that further research on alto trombone transposition be conducted to this end. ${ }^{257}$ In trying to piece together a cohesive rationale against transposition, selected quotes from various sources specific to the alto trombone are addressed.

\section{a. Pedagogical Books}

\section{Benny Sluchin: Study Material for the Alto Trombone.}

The second method [transposed bass-clef] works right away, of course, and it could make the alto more accessible for some people. But, as the alto is shorter, its positions are closer together and require practice. The response of the alto is also different from that of the tenor. Mastering the instrument consists of more than just producing notes. One has to have a deeper knowledge of the instrument, its special intonation and the best way to set the air column in vibration. ${ }^{258}$

At first, Sluchin's statement appears to present a benefit to transposition ("works right away") followed by several solid reasons why transposition is ultimately not the best choice. However, Sluchin's caveat lists only drawbacks that are inevitable on alto regardless of notation (namely the shorter slide, different response, intonation, and different air resistance). Sluchin's acknowledgement of the immediate gains of using transposition is significant-particularly in light of the fact that he opts not to describe any advantages of playing the alto trombone at concert-

\footnotetext{
256 Warner, Current Trends. .., pp. 31-32.

257 Ibid., p. 115.

${ }^{258}$ Sluchin, Study Material for the Alto Trombone, vol. 1, p. 18.
} 
pitch. Physical obstacles on alto trombone are unavoidable (the difference in slide length, etc.); the use of transposition offers a much shorter learning curve for playing written music that could indeed "make the alto more accessible." b. Periodical Articles

\section{Joel Elias: "Rediscovering the Alto Trombone.", The Instrumentalist.}

The Anderson book includes bass-clef studies on the left-hand page and alto clef on the facing page. A player may choose to then treat the Eb alto as a transposing instrument by reading the left-hand pages and playing the same positions as on a $\mathrm{Bb}$ tenor trombone. The instrument will sound the pitches on the right-hand page. Reading only the right-hand pages entails learning new positions on the alto trombone because the trombonist now plays each note as it sounds. Although Anderson notes that every system has strengths and weaknesses, the method of simply learning new alto trombone positions often proves to be easiest. ${ }^{259}$

Elias unfortunately does not afford further insight as to why relearning positions is easiest, and offers no evidence to back up this opinion. Therefore the specifics of his position cannot be addressed.

\section{Donald Appert: “The Alto Trombone: Its Uses, Problems and Solutions.", ITA Journal.}

After obtaining good equipment, one must relearn several things. The seven positions on the Alto Trombone are not only smaller or shorter but also produce different pitches than on the Tenor Trombone... It is important to learn the slide positions for the actual note rather than trying to transpose to Tenor Trombone. This will make sight-reading and overall performance more consistent considering that the music to be played may be either in [non-transposed] Bass, Tenor, Alto, or Treble Clef. 260

Appert broaches what is, at least, the most reasoned standpoint against alto transposition-the advantage of concert-pitch when sight-reading on alto trombone

\footnotetext{
${ }^{259}$ Elias, "Rediscovering the Alto Trombone.", p. 56.

${ }^{260}$ Appert, "The Alto Trombone: Its Uses, Problems and Solutions.", p.13.
} 
and navigating the inconsistencies of clef choice among publishers. As proof of the notational whims of publishers, some of Appert's own compositions for alto trombone and piano are sold with two alternate trombone parts (one in alto clef, and one in transposed bass clef) despite his obvious aversion to transposed parts. 261 However, Appert apparently does not consider concert-pitch to be the factor that improves "overall performance" on alto. His article goes on to acknowledge the many challenges, such as interval accuracy, that are problematic for alto and tenor trombonists regardless of notation. Therefore, the crux of his line of reasoning against transposition must be that most alto trombone literature is not available with transposed parts. Appert addresses neither the capacity to sight-read transposed parts on alto, nor the frequency of situations that necessitate sightreading on alto. ${ }^{262}$ Appert's later assertion that the ideal (and perhaps more common) scenario permits a month of preparation preceding an alto trombone performance ameliorates his criticisms of transposition. With Appert's advised time constraints, rewriting the alto part is a manageable burden that also could make alto performance "more consistent"; playing the alto without the ingrained training of tenor trombone technique as a foundation could result in mental slips in clef reading/slide position coordination. ${ }^{263}$ Moreover, a host of technological advances such as music scanners, notation software, and digital music stands has made it much easier to rewrite parts when necessary; some such devices (although liable to be outmoded even before the completion of this project!) are listed in Appendix E.

\section{c. Dissertations}

David Mathie: The Alto Trombone: Twentieth-Century Performance Practices and Pedagogy in the United States.

-the increase in popularity of the alto trombone in the $1980 \mathrm{~s} . .$. also led to the

\footnotetext{
261 see Appendix C of the current study.

${ }^{262}$ Curiously, the topic of sight-reading on alto trombone was not specifically addressed anywhere in the literature.

263 Lawrence Mitchell, A Comprehensive Performance Project in Trombone Literature With an Essay Consisting of Performance Editions of Selected Intermediate Level Solos Transcribed and Edited for E-Flat Alto Trombone and Piano (DMA Essay, University of Iowa, 1987), pp. 17-18.
} 
publication of pedagogical/method books specifically designed to aid the tenor trombonist in learning skills needed to perform on an alto trombone. This learning process is more elaborate than the comparable switch from trumpet to piccolo trumpet, or CC tuba to F tuba. Three factors are involved: first, adjusting to a smaller instrument and mouthpiece; second, learning the new note positions for an instrument pitched in Eb rather than Bb; and third, coping with the pitch placement problems created by the alto trombone's shorter slide. ${ }^{264}$

Firstly, for clarification, Mathie's three defining factors in the switch from tenor to alto trombone are also his grounds that learning the alto is more involved than switching to secondary instruments for other brass instruments. Any brass player switching to a secondary instrument will necessarily encounter Mathie's first factor regarding adjustments to a different-sized instrument and new harmonic series. Presumably, Mathie considers the switch to alto "more elaborate" because of his second and third factors-relearning slide positions and the alto's shorter slide. Obviously, the requirement of a trombonist to adjust to the shorter slide of the alto is inescapable, but the use of transposition would eliminate the encumbrance of Mathie's second factor. Mathie overlooks a fourth element, that the switch from tenor to alto in traditional concert-pitch notation also entails alto clef facility, a clef generally less comfortable for trombonists than tenor or bass clef. ${ }^{265}$ Therefore, Mathie's strategy for playing alto trombone encompasses four components: 1) the smaller instrument, 2) new slide positions, 3) the shorter slide, and 4) alto clef literacy. With transposition, the only difference between alto trombone and any other secondary brass instrument is the physical variance of a shorter slide.

\section{David Johansen: An Essay consisting of an Examination of Alto Trombone Use ...}

The chief difficulties with this method [Anderson] are the first and third approaches described by Anderson, whereby the student first learns the new placement of positions as they relate to tenor trombone in bass clef. The student follows these procedures by transposing (by writing or reading) the part into bass

\footnotetext{
264 David Mathie, The Alto Trombone..., p. 85

265 Mitchell, A Comprehensive Performance Project. .., p. 17; also see Johansen, An Essay. .., p. 53.
} 
clef. It would seem that since the alto trombone is so radically different from the tenor trombone, it would be more helpful for the student to learn alto trombone positions for the written pitch in alto clef. Many trombonists feel somewhat less comfortable in alto clef than in tenor or bass, and the imposition of the task of transposition while in alto clef may prove to be an unwarranted burden. For these reasons, it might be wise to disregard the left-hand pages and have the student concentrate all of his energy on learning the new positions as they relate to alto clef note placement instead of treating the alto trombone as a small tenor. ${ }^{266}$

Johansen's statement can be summarized into the following points: 1) transposition on alto trombone should be avoided altogether because the alto is "radically different" from the tenor, 2) alto clef is less familiar to trombonists than bass or tenor clef, and 3) transposition with simultaneous clef visualization (Anderson's alternate method of transposition wherein parts do not need to be rewritten) may be cumbersome. Anderson notes that transposition coupled with clef visualization is "a technique often used by performers on the horn and trumpet, but rarely by trombonists." 267 Although surveys have found Anderson's Method to be widely used, no respondents reported using the clef visualization approach to alto, using instead the (rewritten) transposed parts or traditional parts in concert-pitch alto clef. ${ }^{268}$ Johansen, while acknowledging that alto clef is less comfortable to trombonists, ignores the fact that the use of transposition eliminates alto clef. Johansen does not delineate the differences between alto and tenor, but even with alto clef fluency factored out, the alto trombone's concert-pitch slide positions are necessarily a dissimilarity between the two instruments. Because the transposing approach eliminates disparities between alto and tenor, it is difficult to rationalize Johansen's opinion that the alto trombone being "radically different" precludes using transposition. Allowing for inevitable physical changes and timbral

\footnotetext{
266 Johansen, An Essay..., p.53

${ }^{267}$ Anderson, A Complete Method for Eb Alto Trombone, p. ii.

268 Mathie, The Alto Trombone..., pp. 86-87. Warner's study also found Anderson's Method to "most popular" but was not specific about which approach within the Anderson was employed, p. 85.
} 
considerations $^{269}$, the alto trombone is, after all, still a trombone. Lawrence Isaacson, of the Boston Conservatory, remarked:

The alto trombone need not be approached technically any differently from the tenor trombone... Once the instrument is mastered, it can be picked up several weeks before the first rehearsal and no complications should occur. Let's not make this into such a foreign concept for students. ${ }^{270}$

The use of transposition furthers this line of reasoning.

Lawrence Mitchell. A Comprehensive Performance Project in Trombone Literature... Another slide-related problem often arises when the tenor trombone player reads music while playing the alto. The reading of alto clef is rarely as comfortable as reading tenor or bass clef, even under the best of circumstances. This problem coupled with the changed slide patterns presents an even greater challenge to the trombonist. The patterns of the slide positions to which the tenor trombonist is accustomed often fail to fit the music being read. The eye/brain co-ordination so carefully trained over the years can no longer act reflectively [reflexively?] for the once familiar patterns now sound different pitches. This problem is often aggravated when reading alto clef on the alto trombone... If the trombonist does not feel at ease with ... these options, he or she may choose to approach the learning of the alto trombone by reading transposed bass clef. This will allow the student the use of traditional slide positions while reading alto clef music as concert bass clef. 271

Mitchell's rationale for transposition aptly summarizes the position of the current study, but also advances a closing argument with the words "options" and "may choose." At its best, any attempt to dismantle the anti-transposition viewpoint can only persuade towards, rather than prove, the advantages of the transposing

\footnotetext{
${ }^{269}$ see Mark Hartman, The Use of the Alto Trombone in Symphonic and Operatic Orchestral Literature (DMA Research Paper, Arizona State University, 1985), pp. 57-61.

270 Lawrence Isaacson as quoted in Mathie, p. 164.

271 Mitchell, A Comprehensive Performance Project. .., pp. 17-18.
} 
approach. The subjective nature of musical achievement is not something that can be verified in terms of one system of notation versus another. Simply put, notational choices are largely a matter of preference. Even Warner's proposal for further research, involving a statistical analysis of the progress outcome from two test groups of alto trombonists (one group using transposition, one group reading concert-pitch), ${ }^{272}$ would not be conclusive on an individual basis. While the current study is a proponent of the universal acceptance of the transposing approach to alto, the higher purpose here has been merely to defend and legitimatize transposed alto parts as a viable alternative to tradition. Emulating Warner, the discourse of the current study is not intended to prove but to "yield useful results to those who do not have time or resources to do their own tests and comparisons." 273

\footnotetext{
272 Warner, Current Trends. .., p. 115.

273 Ibid.
} 


\section{CONCLUSIONS}

A review of trombone notational history has yielded that the pairing of alto clef and alto trombone was logical for the time-period in which this system was implemented. The tradition of writing trombone parts to correspond with vocal ranges and clefs began during the Renaissance, a time when the trombone was primarily used as an instrument to double the voice. Throughout the centuries of expanded trombone utility, the alto has consistently remained secondary to the tenor trombone. As a secondary instrument, performing on alto trombone entails a transition from the tenor trombone. With interest in the alto trombone still waxing during its era of "rebirth", there exists an onus to make performance on this instrument more accessible. Clearly, transposition serves this purpose by eliminating the factors most dissimilar to performance on tenor trombone-namely, reading alto clef and coping with a new series of slide positions.

The only valid argument against alto transposition that has been extricated from the preceding section of literature cross-examination is that there exists a dearth of available transposed alto literature. The advent of technological advancements such as digital scanners, notation software, and score translation programs ${ }^{274}$ ameliorates the inconvenience of rewriting music, thus making transposed parts easier to obtain for contemporary trombonists. However, the fact that published research has not produced an irrefutable argument against the method of transposing for alto should not imply that there are inherent disadvantages to clef reading prowess. On the contrary, navigating notational variations is a marketable and/or necessary skill for many performing musicians. Obviously, competent musicians must interpret and perform from whatever notation is set before them, and may even benefit from arcane or obscure knowledge. For instance, trombonist and clinician Matt Niess related being able to secure a lucrative yet unexpected job opportunity playing horn lines on trombone

${ }^{274}$ See Appendix E for some specific examples. 
because of his proficiency at reading mezzo-soprano clef. ${ }^{275}$ The intent of the current study therefore is not to debate the limits of literacy ability, nor to challenge the bravado of musicians in terms of the quantity of notational deviations one can successfully decipher, but rather to endorse comprehensive notational reform as the most logical basis for the alto trombone's pedagogical foundation.

In recent decades, alto trombone pedagogy has been complemented by an abundance of method books. Several pedagogical approaches to transposing alto trombone have been reviewed:

1) Transposed bass clef (via Anderson's Method) in which traditional concert-pitch alto clef parts need to be rewritten down a perfect fourth.

2) Transposed treble clef (via Nøkleby's example for brass band pupils) in which traditional concert-pitch alto clef parts need to be rewritten up a major sixth.

3) Clef visualization (for Db alto trombone as outlined by Flandrin) in which standard concert-pitch alto clef parts are read as if tenor clef by adding 3 sharps.

4) Clef and interval transposition (Anderson's second method of transposition) in which standard concert-pitch alto clef parts are read using one of three varieties of clef and interval visualization.

Two of the listed practical approaches to transposition can be applied to traditional concert-pitch alto clef parts but are nonetheless problematic. Anderson's second method of transposition, seldom used by trombonists, ${ }^{276}$ is likely to be viable only

275 This was one of the many topics covered in Matt Neiss' clinic, "The Lead Trombonist", at the United States Army Band's Eastern Trombone Workshop, March 16, 2002.

276 Mathie, The Alto Trombone. .., pp. 86-87. 
for musicians already adept at interval visualization. Similarly, the method of clef visualization for the $\mathrm{Db}$ alto trombone inevitably requires an instrument that is no longer commonly manufactured. A more feasible approach to alto transposition centers on accessibility to the nearly-abandoned alto trombone pitched in D. Pursuing Saeki's proposal to revitalize obsolete altos, ${ }^{277}$ the reintroduction of the D alto could provide a double benefit for trombonists-offering a more historically accurate instrument selection for specific applications, and a practical means of clef visualization/transposition. Transposition for alto trombones pitched in D could be structured identically to the method for Db alto explicated by Flandrin and Lafosse, but by adding 4 flats to the key signature while visualizing alto clef as tenor clef. So as to avoid the implicit financial burden of owning two secondary instruments, some manufacturers offer D slide attachments for Eb alto trombones. ${ }^{278}$ Other instrument-makers could theoretically offer detachable D slides designed to retrofit older Eb models. However, as the conventional Eb model remains the most prevalent and well established variety, ${ }^{279}$ applications of transposition for the alto trombone currently obligate advance notational emendations.

Curiously, most alto trombone methods have avoided inquiry into the alto's unusual 500-year notational standstill. Many methods oblige the demands of playing alto trombone in traditional concert-pitch alto clef, without formally challenging or specifically defending this type of notation. If an alto trombone method merely assumes that traditional notation offers the most practical approach to the instrument, then that method neglects the evolving nature of music notation itself. Music notation has been described as the product of gradual improvements resulting from long periods of experimentation. ${ }^{280}$ Composer and music notation scholar Gardner Read stated:

\footnotetext{
277 Saeki, “An Historical Perspective of the Alto Trombone.", pp. 96-101.

${ }^{278}$ For example Yamaha, model \#YSL-872. The D slide is in essence a crook.

${ }^{279}$ Sluchin, Study Material for the Alto Trombone, vol. 1, p. 13.

${ }^{280}$ C. F. Abdy Williams, The Story of Notation, p. 1.
} 
Contemporary composers are in almost universal agreement that our traditional system of music notation demands improvement; indeed, some advocate its outright replacement by alternative methods and techniques. These convictions are not, however, a uniquely twentieth-century phenomena; they were shared by many musicians of the past who also sought to alter both the structure of notation and its individual components. Since roughly 1700, composers and theorists, pedagogues and amateur musicians have put forth with notable regularity proposals to simplify, to improve, or to supplant the prevailing system. ${ }^{281}$

\section{Musicologist Richard Rastall corroborated:}

-musical notation is always in a state of change, constantly subjected to pressures which cause it to embrace innovations, to become more explicit, more flexible, or otherwise more suited to the prevailing musical style. ${ }^{282}$

The power of tradition in music is a dominant force when it comes to notation. Obviously, the inherent logic of notational reform has to be convincing enough as to outweigh the cost of implementing such a system. The true cost of notational reform must also factor in the resistance to change due to musicians' comfort with the status quo. Rastall continued:

-most musicians, working on the time-scale of their own lives, regard notation as static. ${ }^{283}$

In the overview chapter of Read's Source Book of Proposed Music Notation Reforms, he discusses notational reform on a grand scale-in terms of altering one or more of accepted standards for the five-line staff, clefs, noteheads, accidentals, etc. Read cites an outline of criteria drawn up by Erhard Karkoschka's Notation in New Music (1972) intended to assess the potential of newly created systems of music notation. Although Karkoschka cautions against opposing tradition without

\footnotetext{
281 Gardner Read. Source Book of Proposed Music Notation Reforms (New York; Westport, Connecticut; London: Greenwood Press, 1987), p.1.

282 Richard Rastall, The Notation of Western Music (New York: St. Martin's Press, 1982), p. 231. 283 Ibid.
} 
sufficient reason, he champions simplification and visual clarity. Held to this scrutiny, the proposal to write alto trombone parts at a transposition (albeit modest in comparison to system-wide organizational revisions) resonates particularly with the eighth and final point in Karkoschka's lexicon of standards (italics added):

What the ear hears must be presented to the eye in such a way that two basic characteristics are taken into consideration: (a) The visual event must be apparent as the direct translation of the auditory event, requiring as few additional thought processes as possible and (b) the individual symbols and the totality of symbols must be formed on an optical basis; they must be "correct" in the visualpsychological sense. ${ }^{284}$

Karkoschka's guidance implies the superiority of notation that is visually comfortable to the performer. Alto trombone parts in concert-pitch alto clef require the "additional thought processes" of alto clef literacy and a foreign series of slide positions. Transposed bass clef parts provide trombonists with familiar visual feedback that is conducive to the learned muscle memory of tenor trombone positions.

Approached in terms of notational reform, justification for the transposing approach to alto trombone is twofold:

1.) Transposition helps to eliminate an overabundance of clefs for trombonists. (As modern notational standards have already limited standard tenor trombone notation to tenor and bass clefs, 285 transposed bass clef parts for the alto trombone would dispose of the use of alto clef for trombones.)

2.) Transposition helps to facilitate the transition from primary (tenor trombone) to secondary instrument (alto trombone).

\footnotetext{
${ }^{284}$ Erhard Karkoschka, Notation in New Music (New York: Praeger Publishers, 1972), p. 15.

285 Gardner Read, Music Notation: A Manual of Modern Practice, $2^{\text {nd }}$ ed., p. 355.
} 
In the wake of the trombone's vast and continuing advance of function, trombonists are left with a questionable notational and pedagogical system for the alto trombone that is propped up by tradition alone. Rather than blindly follow the assumptions of tradition, musical evolution demands that, at some point in time, the inherently more logical system of notational practice be given due consideration. Joining with the contemporary swell of interest in the alto trombone, the current study proposes that alto trombone notation has unequivocally reached that critical juncture. 


\section{APPENDIX A}

CLASSIFICATION OF SPECIFIC PITCH INDICATIONS (ITA CONVENTION)

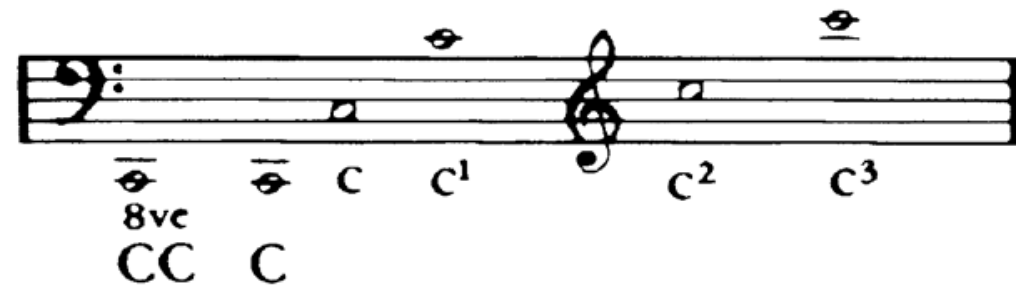




\begin{abstract}
APPENDIX B
LIST OF SYMPHONIC AND OPERATIC ORCHESTRAL WORKS WITH

TROMBONE PARTS FOR WHICH THE ALTO TROMBONE IS APPROPRIATE
\end{abstract}

The primary source of this list is:

Ken Shifrin, The Orchestral Excerpt Series for the Orchestral "Doubler." The

Professional's Handbook of Orchestral Excerpts, Alto Trombone. Virgo Music Publishers, West Midlands, England, 1986.

Supplementary information for this list comes from four sources:

Daniel Cloutier, Ludwig Van Beethoven's Orchestration of the Trombone. DMA Research Project, West Virginia University, 2009.

David Guion, The Trombone: Its History and Music 1697-1811. New York: Gordon and Breach, 1988.

David Mathie, The Alto Trombone: Twentieth-Century Performance Practices and Pedagogy in the United States. DMA Document, University of Georgia, 1993.

Ken Shifrin, "The Alto Trombone in the Orchestra 1800-2000." British Trombone Society [online], 2008. Extracted from PhD Thesis, Oxford University, 2000. Available at <http://www.britishtrombonesociety.org/resources/shifrin/ the-alto-trombone-in-the-orchestra-1800-2000.html>, accessed January 8, 2010.

\begin{tabular}{|c|c|c|}
\hline Composer & Work & Note \\
\hline J.S. BACH & Cantata No. 2 & \\
\hline J.S. BACH & Cantata No. 4 & \\
\hline J.S. BACH & Cantata No. 21 & \\
\hline J.S. BACH & Cantata No. 23 & \\
\hline J.S. BACH & Cantata No. 25 & \\
\hline
\end{tabular}




\begin{tabular}{|c|c|c|}
\hline J.S. BACH & \multicolumn{2}{|l|}{ Cantata No. 28} \\
\hline J.S. BACH & \multicolumn{2}{|l|}{ Cantata No. 38} \\
\hline J.S. BACH & \multicolumn{2}{|l|}{ Cantata No. 64} \\
\hline J.S. BACH & \multicolumn{2}{|l|}{ Cantata No. 68} \\
\hline J.S. BACH & \multicolumn{2}{|l|}{ Cantata No. 96} \\
\hline J.S. BACH & \multicolumn{2}{|l|}{ Cantata No. 101} \\
\hline J.S. BACH & \multicolumn{2}{|l|}{ Cantata No. 118} \\
\hline J.S. BACH & \multicolumn{2}{|l|}{ Cantata No. 121} \\
\hline BARTOK & \multicolumn{2}{|l|}{ Blue Beard's Castle } \\
\hline BEETHOVEN & \multicolumn{2}{|l|}{ Christ on the Mount of Olives } \\
\hline BEETHOVEN & \multicolumn{2}{|c|}{ Consecration of the House Overture } \\
\hline BEETHOVEN & \multicolumn{2}{|l|}{ It Is Accomplished } \\
\hline BEETHOVEN & \multicolumn{2}{|l|}{ King Stephan } \\
\hline BEETHOVEN & \multicolumn{2}{|c|}{ Leonore/Fidelio Overture No. 2 (1805) } \\
\hline BEETHOVEN & \multicolumn{2}{|c|}{ Leonore/Fidelio Overture No. 3 (1806) } \\
\hline BEETHOVEN & \multicolumn{2}{|l|}{ Missa Solemnis } \\
\hline BEETHOVEN & \multicolumn{2}{|l|}{ Ruins of Athens } \\
\hline BEETHOVEN & \multicolumn{2}{|l|}{ Symphony No. 5} \\
\hline BEETHOVEN & \multicolumn{2}{|l|}{ Symphony No. 6} \\
\hline BEETHOVEN & \multicolumn{2}{|l|}{ Symphony No. 9} \\
\hline BEETHOVEN & \multicolumn{2}{|l|}{ The Glorious Moment } \\
\hline BEETHOVEN & \multicolumn{2}{|l|}{ Wellington's Victory } \\
\hline BERG & Altenberg Lieder & double on tenor \\
\hline BERG & \multicolumn{2}{|l|}{ Drei Bruchstucke-“Wozzeck” } \\
\hline BERG & Wozzeck & double on tenor \\
\hline BERG & \multicolumn{2}{|l|}{ Lulu } \\
\hline BERG & Three Pieces for Orchestra & double on tenor ${ }^{*}$ \\
\hline BRAHMS & \multicolumn{2}{|l|}{ Academic Festival Overture } \\
\hline
\end{tabular}

* Although the score does not designate the $1^{\text {st }}$ trombone part as doubling on alto and tenor, Berg specified that the first part was for alto and then wrote several passages that extend below the low range of the alto trombone. 


$\begin{array}{ll}\text { BRAHMS } & \text { German Requiem } \\ \text { BRAHMS } & \text { Gesang der Parzen } \\ \text { BRAHMS } & \text { Nänie } \\ \text { BRAHMS } & \text { Schicksalslied } \\ \text { BRAHMS } & \text { Symphony No. } 1 \\ \text { BRAHMS } & \text { Symphony No. } 2 \\ \text { BRAHMS } & \text { Symphony No. } 3 \\ \text { BRAHMS } & \text { Symphony No. } 4 \\ \text { BRAHMS } & \text { Tragic Overture } \\ \text { BRAHMS } & \text { Triumphlied } \\ \text { BRITTEN } & \text { The Building of the House } \\ \text { BRITTEN } & \text { The Burning, Fiery Furnace } \\ \text { BRUCKNER } & \text { Mass in E Minor } \\ \text { BRUCKNER } & \text { Mass in F Minor } \\ \text { DVORAK } & \text { Requiem } \\ \text { DVORAK } & \text { Stabat Mater } \\ \text { DVORAK } & \text { Te Deum } \\ \text { FUX } & \text { Missa brevis solennitatis } \\ \text { FUX } & \text { Missa Corporis Christi } \\ \text { FUX } & \text { Missa Lachrymantis Virginis } \\ \text { FUX } & \text { Missa Purificationis } \\ \text { FUX } & \text { Missa Sanctissimae Trinitas } \\ \text { GLUCK } & \text { Alceste } \\ \text { GLUCK } & \text { Echo et Narcisse } \\ \text { GLUCK } & \text { Iphigénie en Tauride } \\ \text { GLUCK } & \text { Orpheé et Euridice } \\ \text { HANDEL } & \text { Israel in Egypt } \\ \text { HANDEL } & \text { Samson (march only) } \\ & \\ \text { Bisputable } \\ \text { B* } \\ \text { Bisputable }\end{array}$

\footnotetext{
** These three works by Dvorak are included in Shifrin's Handbook of Orchestral Excerpts in seeming contradiction with Shifrin's article, "Trombone Myth Busters No. 1: Dvorak Wrote for the Alto Trombone." ITA Journal 25 (Spring 1997): pp. 30-31.
} 


\begin{tabular}{|c|c|c|}
\hline HANDEL & \multicolumn{2}{|l|}{ Saul } \\
\hline HAYDN & \multicolumn{2}{|l|}{ The Creation } \\
\hline HAYDN & \multicolumn{2}{|l|}{ The Seasons } \\
\hline HAYDN & \multicolumn{2}{|c|}{ The Seven Last Words ... } \\
\hline HAYDN & \multicolumn{2}{|l|}{ Te Deum } \\
\hline MAHLER & Symphony No. 6 & double on tenor \\
\hline MAHLER & Symphony No. 7 & opt. double on tenor \\
\hline MENDELSSOHN & \multicolumn{2}{|l|}{ Athalia Overture } \\
\hline MENDELSSOHN & \multicolumn{2}{|c|}{ Ein Sommernachtstraum } \\
\hline MENDELSSOHN & \multicolumn{2}{|l|}{ Elijah Oratorio } \\
\hline MENDELSSOHN & \multicolumn{2}{|l|}{ Hymn of Praise } \\
\hline MENDELSSOHN & \multicolumn{2}{|l|}{ Ruy Blas Overture } \\
\hline MENDELSSOHN & \multicolumn{2}{|l|}{ Symphony No. 2} \\
\hline MENDELSSOHN & \multicolumn{2}{|l|}{ Symphony No. 5} \\
\hline MEYERBEER & \multicolumn{2}{|c|}{ Kronungsmarsch-"The Prophet" } \\
\hline MONTEVERDI & \multicolumn{2}{|l|}{ Orfeo } \\
\hline MONTEVERDI & \multicolumn{2}{|l|}{ Marien Vesper } \\
\hline MOZART & \multicolumn{2}{|l|}{ Davidde Penitente } \\
\hline MOZART & \multicolumn{2}{|c|}{ Missa Brevis (K.V. 61a) } \\
\hline MOZART & \multicolumn{2}{|c|}{ “Credo" Mass (K.V. 257) } \\
\hline MOZART & \multicolumn{2}{|c|}{ “Coronation” Mass (K.V. 317) } \\
\hline MOZART & \multicolumn{2}{|l|}{ Don Giovanni } \\
\hline MOZART & \multicolumn{2}{|c|}{ Litaniae de B.M.V. (K.V. 74e) } \\
\hline MOZART & \multicolumn{2}{|c|}{1772 Litaniae de venerabili altaris sacramento (K.V. 125) } \\
\hline MOZART & \multicolumn{2}{|l|}{ Idomeneo } \\
\hline MOZART & \multicolumn{2}{|c|}{1789 Orchestration of Handel's Messiah } \\
\hline MOZART & \multicolumn{2}{|l|}{ Die Zauberflöte } \\
\hline MOZART & \multicolumn{2}{|c|}{ “Waisenhauskirche” Mass (K.V. 47a) } \\
\hline MOZART & \multicolumn{2}{|c|}{ Missa Solemnis (K.V. 337) } \\
\hline MOZART & \multicolumn{2}{|c|}{ Mass in c minor (K.V. 417a) } \\
\hline MOZART & \multicolumn{2}{|l|}{ Requiem } \\
\hline
\end{tabular}




\begin{tabular}{|c|c|c|}
\hline MOZART & Schuldigkeit des Ersten Gebotes & \\
\hline MOZART & Vesperae Solennes de Confessore & \\
\hline SCHOENBERG & Gurre-Lieder & \\
\hline SCHOENBERG & Pelleas et Melisande & \\
\hline SCHUBERT & Mass No. 1 & \\
\hline SCHUBERT & Mass No. 5 & \\
\hline SCHUBERT & Mass No. 6 & \\
\hline SCHUBERT & Symphony No. 8 "Unfinished" & \\
\hline SCHUBERT & Symphony No. 9 & \\
\hline SCHUBERT & Zauberharfe Overture & \\
\hline SCHUMANN & Symphony No. 1 & \\
\hline SCHUMANN & Symphony No. 2 & \\
\hline SCHUMANN & Symphony No. 3 & \\
\hline SCHUMANN & Symphony No. 4 & \\
\hline SCHUTZ & Geburt Jesu Christi & \\
\hline SCHUTZ & Magnificat & \\
\hline STRAUSS, R. & Die Frau ohne Schatten & \\
\hline STRAVINSKY & The Flood & double on tenor \\
\hline STRAVINSKY & Threni & \\
\hline THOMAS, A. & Hamlet & \\
\hline THOMAS, A. & Le Compte de Carmagnola & \\
\hline WEBER & Der Freischutz Overture & \\
\hline WEBER & Euryanthye Overture & \\
\hline WEBER & Oberon Overture & \\
\hline
\end{tabular}




\section{APPENDIX C \\ SOLO LITERATURE FOR ALTO TROMBONE CURRENTLY \\ AVAILABLE WITH TRANSPOSED BASS CLEF PARTS}

The following inventory of solos has been compiled from two lists:

Stephen Anderson, "The Alto Trombone, Then and Now." The Instrumentalist 40 (November 1985): pp. 54-62.

Robert Kehle, Alto Trombone Literature: An Annotated Guide, $2^{\text {nd }}$ Edition (Coventry, England: Warwick Music Limited, 2005), §D-E, pp. 15-33.

Solos:

Albrechtsberger, J. G. Concerto (1769). Editio Musica Budapest. Transposed bass clef part available in Anderson's Method.

Anonymous (18 ${ }^{\text {th }}$ century), Lamento. Modern Editions. Distributed by Kagarice Brass Editions, Box 5302, Denton, TX, 76203, USA.

Appert, Donald L. Canticle for Alto Trombone and Piano (1986). TAP Music Sales.

Appert, Donald L. Maskil (1985). Modern Editions. Distributed by Kagarice Brass Editions, Box 5302, Denton, TX, 76203, USA.

Haydn, Michael. Larghetto [extracted from Sinfonia, Perger Number 34 (1763). Edited and arranged by Randy Kohlenberg. Modern Editions. Distributed by Kagarice Brass Editions, Box 5302, Denton, TX, 76203, USA.

Haydn, Michael. Concerto [extracted from Divertimento in D (1764)]. Edited and arranged by Randy Kohlenberg. Modern Editions. Distributed by Kagarice Brass Editions, Box 5302, Denton, TX, 76203, USA. 
Marek, Robert. Sonatina (1985). Available from Mike Marek, Vermillion, SD, USA.

Müller, Carlo. Plautus animae (c. 1780). Modern Editions. Distributed by Kagarice Brass Editions, Box 5302, Denton, TX, 76203, USA.

Mozart, Leopold. Concerto (c. 1762). Edition Eulenberg, or Ludwig Music Publishing Company. Transposed bass clef part available in Anderson.

Potter, David. Canzonetta for Alto Trombone and Piano. (1982). Available from the composer. San Antonio, TX, USA.

Prescott, John. Suite for Alto Trombone and Piano, Op. 18 (1986). Modern Editions. Distributed by Kagarice Brass Editions, Box 5302, Denton, TX, 76203, USA.

Reutter, Georg. "Gloria" from Missa Sancti Caroli (1734). Modern Editions. Distributed by Kagarice Brass Editions, Box 5302, Denton, TX, 76203, USA.

Ritter-George, Thom. Sonata for Alto Trombone and Piano. (1986). Available from the composer: 311 South $8^{\text {th }}$ Avenue, Pocatello, ID, 83201,USA.

Tuma, Franz Ignaz. "Almo Factori” from Motteto de Tempori (1742). Modern Editions. Distributed by Kagarice Brass Editions, Box 5302, Denton, TX, 76203, USA.

Tuma, Franz Ignaz. Inno Per Il Festo di St. Teresia (1741). Modern Editions. Distributed by Kagarice Brass Editions, Box 5302, Denton, TX, 76203, USA.

Wagenseil, G. C. Concerto (c.1755). Universal Edition, or Willy Mueller. Transposed bass clef part available in Anderson. 
Ziani, Marc Antonio. "Virgo, virgo prius" from Alma Redemptoris Mater (1705).

Modern Editions. Distributed by Kagarice Brass Editions, Box 5302, Denton, TX, 76203, USA.

The following transcriptions are printed with transposed bass clef parts in Lawrence Mitchell's DMA Essay: A Comprehensive Performance Project in Trombone Literature With an Essay Consisting of Performance Editions of Selected Intermediate Level Solos Transcribed and Edited for E-Flat Alto Trombone and Piano (1987), available through Inter-Library Loan from the University of Iowa:

Vaghe Stelle by Francesco Cavalli

Nina by Giovanni Pergolesi

Bourree by William Babell

Gavotte by Giambattista Martini

Largo and Tambourin by Gabriel Guillemain

Homesickness III by Johannes Brahms

Remembrance by Johannes Brahms

Magyar Song by Johannes Brahms

Memories by David Popper

Album Leaf by Richard Wagner 


\begin{abstract}
APPENDIX D
LIST OF REVIEWS OF ALTO TROMBONE PEDAGOGICAL MATERIALS AS

PUBLISHED IN THE INTERNATIONAL TROMBONE ASSOCIATION JOURNAL
\end{abstract}

In addition to the overview provided by Kimball and Hansen's article, "Alto

Trombone Pedagogical Materials," 286 the following alto trombone study materials

and methods have been reviewed in the Literature Reviews section of the ITA Journal (see Table 3, p. 53 for quick reference):

Anderson, Stephen. A Complete Method for Eb Alto Trombone (1984).

REVIEW: $\quad$ ITA Journal 12/2 (April 1984) by Royce Lumpkin.

Blazhevich, Vladislav. School for Trombone in Clefs including The All New Alto Studies (2008 edition by Kharlamov and Deryugin).

REVIEW: ITA Journal-forthcoming by J. Mark Thompson

Edwards, Brad. Introductory Studies in Tenor and Alto Clef (2002).

REVIEW: $\quad$ ITA Journal 32/2 (April 2004) by Paul Overly.

Harvey, Roger. BrassWorkBook for Alto Trombone (1998).

REVIEW: $\quad$ ITA Journal 28/4 (Fall 2000) by Will Kimball.

Kehle, Robert. Alto Trombone Literature: An Annotated Guide, 1st ed.(1998).

REVIEW: $\quad$ ITA Journal 28/2 (Spring 2000) by Will Kimball.

Naulais, Jérôme. 20 Etudes variées Sur la Virtuosité: Le Style et le Rhythm, \#14,

Trombone Alto (1988).

REVIEW: $\quad$ ITA Journal 33/4 (October 2005) by Kevin Chiarizzio.

286 Will Kimball and Joseph Hansen. "Alto Trombone Pedagogical Materials." ITA Journal 35 (January 2007): pp. 44-46. 
Maxted, George. 20 Studies for Tenor Trombone (1954).

REVIEW: $\quad$ ITA Journal 22/4 (Fall 1994) by John Mead.

Mullen, Robert. 32 Etudes for Alto Trombone (1984).

REVIEW: $\quad$ ITA Journal 15/4 (Fall 1987) by Joel Elias.

Parow, Karsten. Initiation Complete au Trombone Alto (1982).

REVIEW: ITA Journal 14/4 (Fall 1986) by Joel Elias.

Shifrin, Ken. The Professional's Handbook of Orchestral Excerpts, Alto Trombone (1987).

REVIEW: $\quad$ ITA Journal 15/4 (Fall 1987) by John Marcellus.

Uber, David. First Studies in Alto Clef (1989).

REVIEW: $\quad$ ITA Journal 17/1 (Winter 1989) by Ron Babcock.

Uber, David. Symphonic Studies in Alto Clef(1992).

REVIEW: $\quad$ ITA Journal 23/4 (Fall 1995) by Bill Stanley. 


\section{APPENDIX E}

\section{A FEW COMMON ORCHESTRAL ALTO TROMBONE PARTS REWRITTEN IN TRANSPOSED BASS CLEF}

Appendix E includes transposed bass clef alto trombone parts from the following works:

1. BEETHOVEN-Symphony No. 5

2. BRUCKNER-E Minor Mass

3. HAYDN-The Creation

4. MENDELLSOHN-Symphony No. 5

5. MOZART-Requiem

6. SCHUBERT-"Great" Symphony in C Major (No. 9)

7. SCHUMANN-Symphony No. 3 "Rhenish"

Every effort was made to maintain the formatting of the original concert-pitch alto clef parts. Transposed alto trombone parts for these works were previously unavailable. The following music notation technology was used in the rewriting process:

Notation software: Finale 2008

Music scanning/translation programs: SmartScore X Pro

Original parts were scanned into a computer using an HP Officejet J4680 All-in-One scanner, corrected, and then transposed down a perfect fourth with Finale 2008. Finally, parts were transferred from alto clef to bass clef. 


\title{
Fünfte Symphonie
}

\author{
TROMBONE ALTO
}

(Transposed)

L. van Beethoven, Op. 67

Allegro con brio tacet. Andante con moto tacet

Allegro $d=96 \quad \mathbf{6} \quad$ poco ritard. a tempo

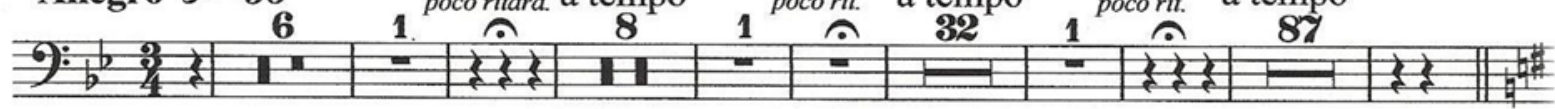

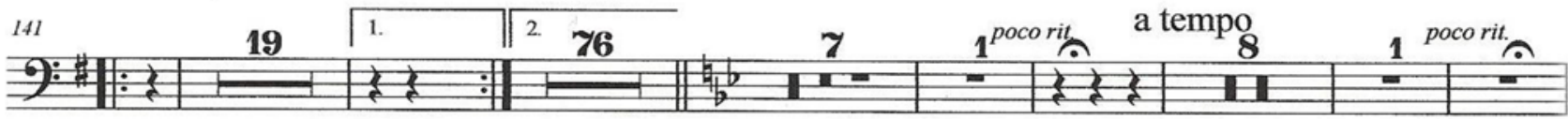

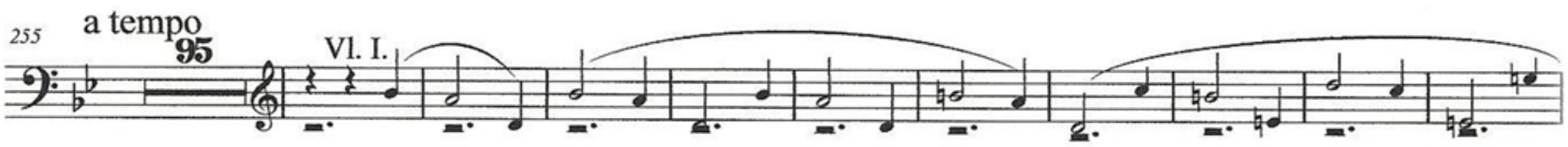

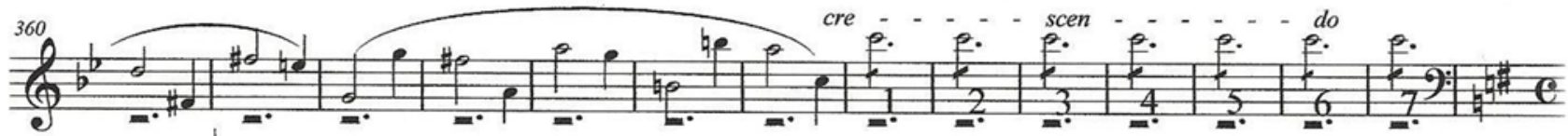

Allegro $d=84$

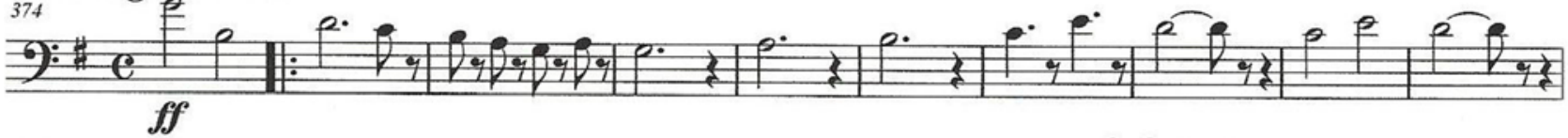

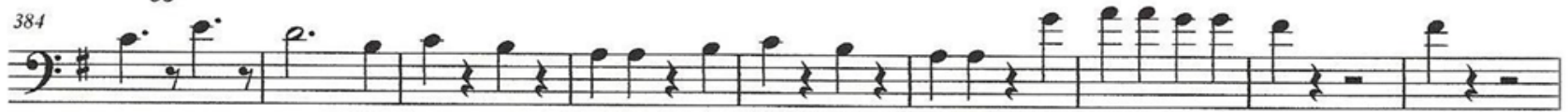

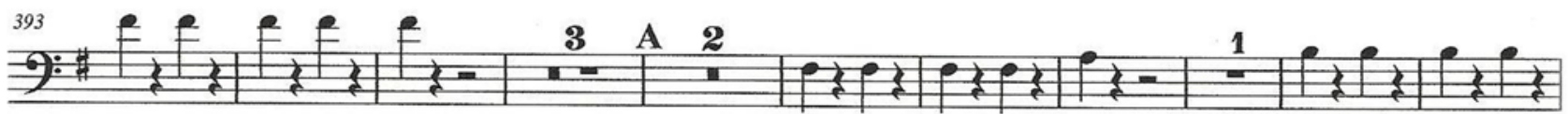

年:

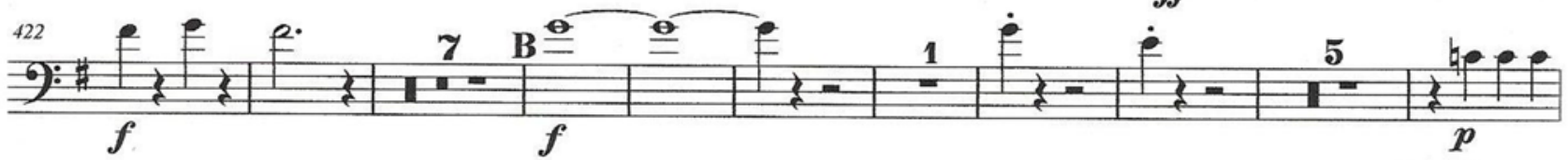

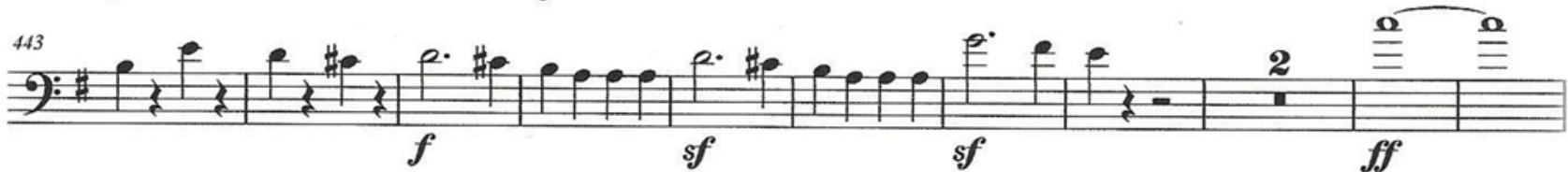

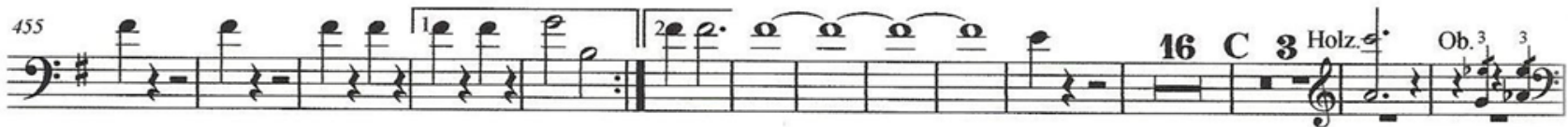




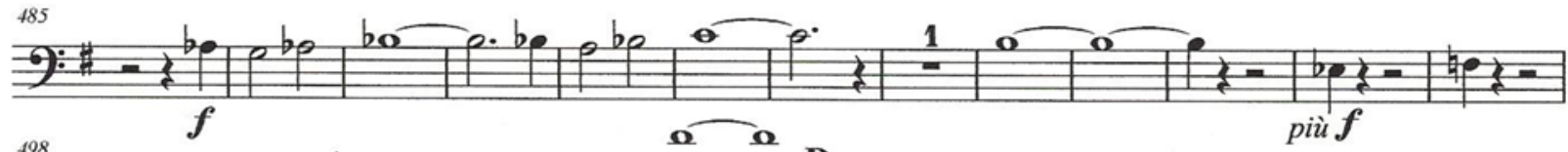

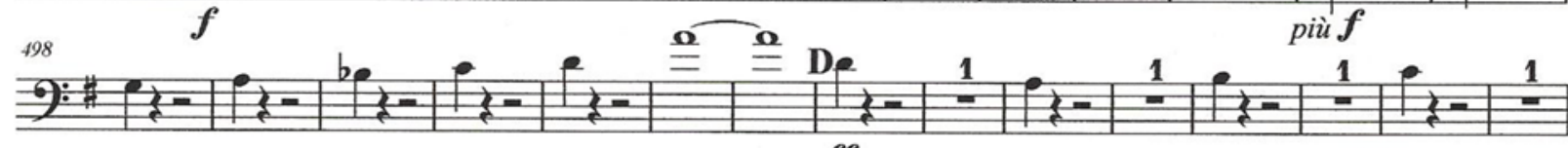



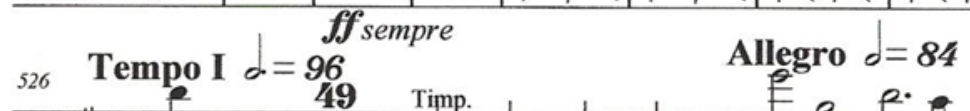

9:

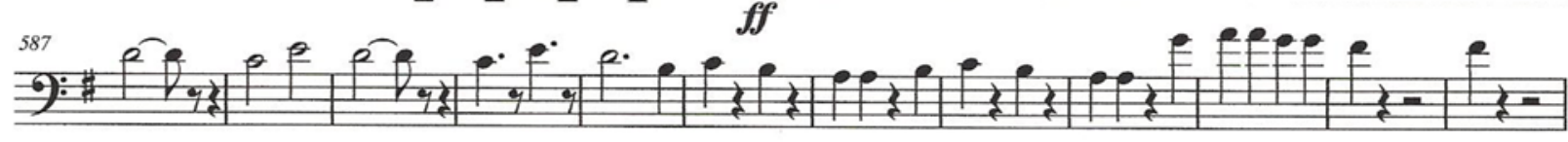

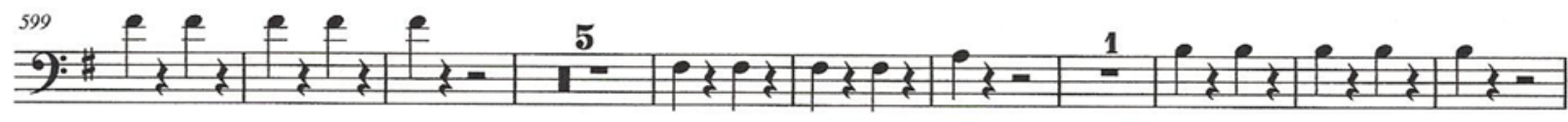

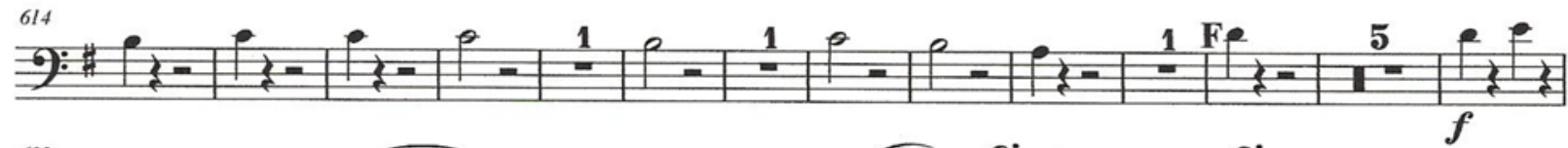

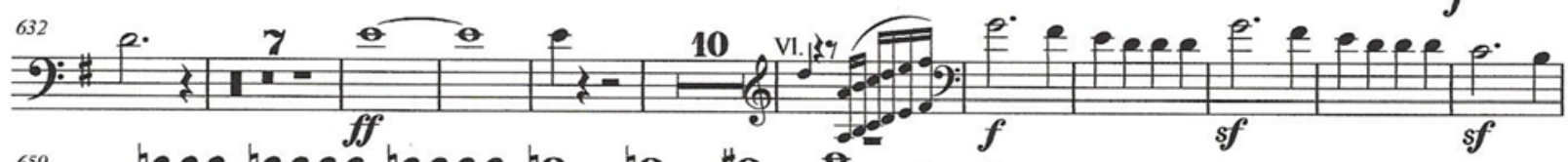

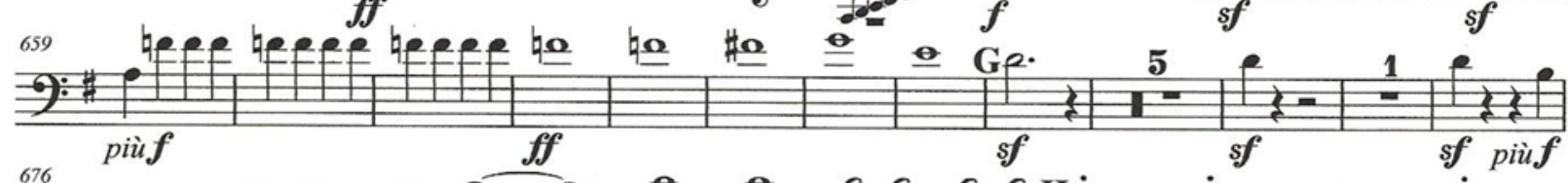

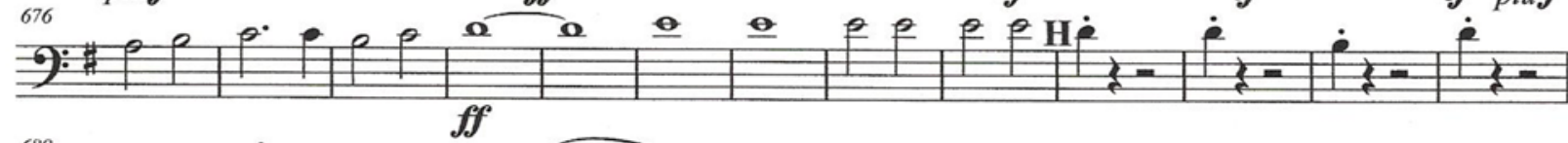



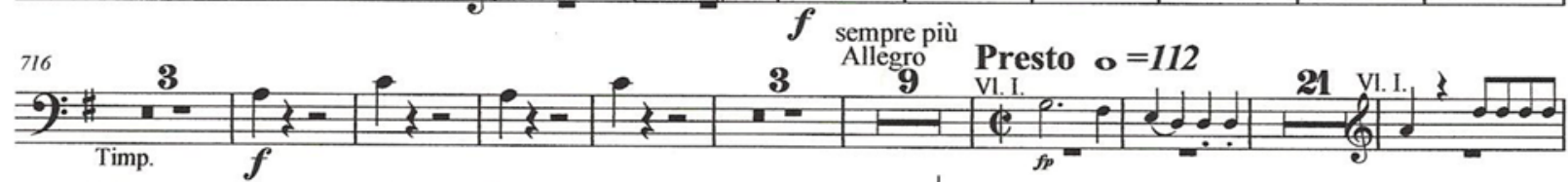

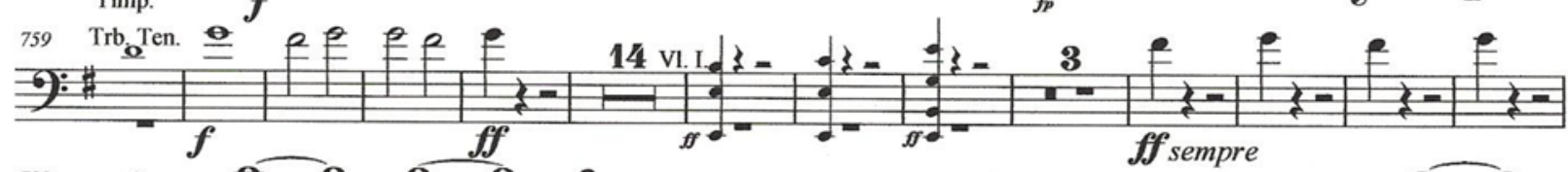

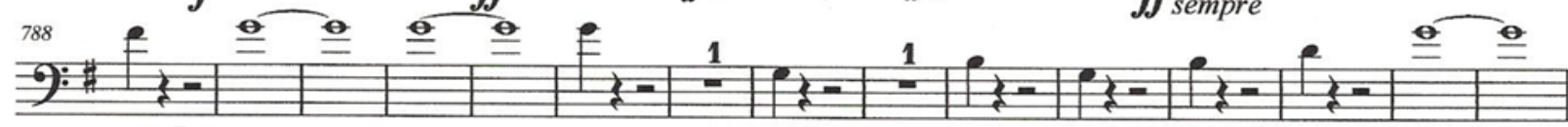

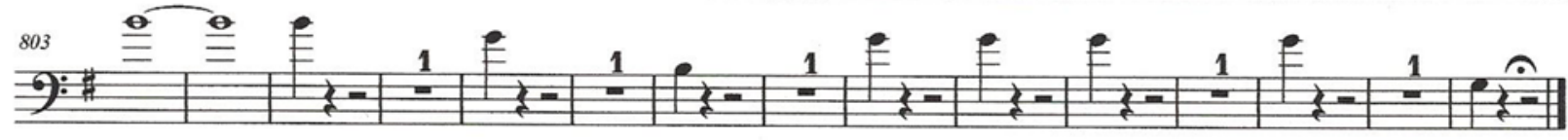




\title{
MESSE E-MOLL
}

2. Fassung 1882

Anton Bruckner (1824-1896)

\begin{abstract}
Alt-Posaune
(transposed)
\end{abstract}

\section{KYRIE}

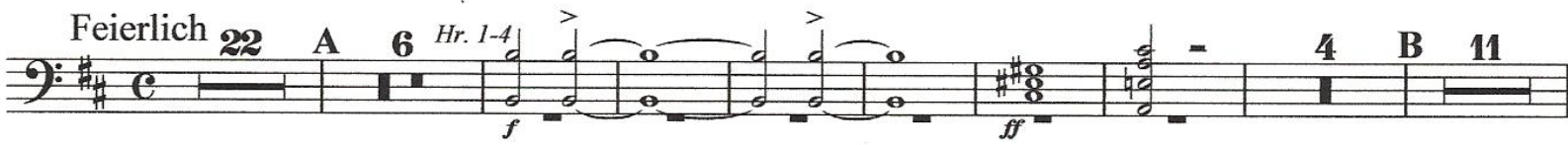
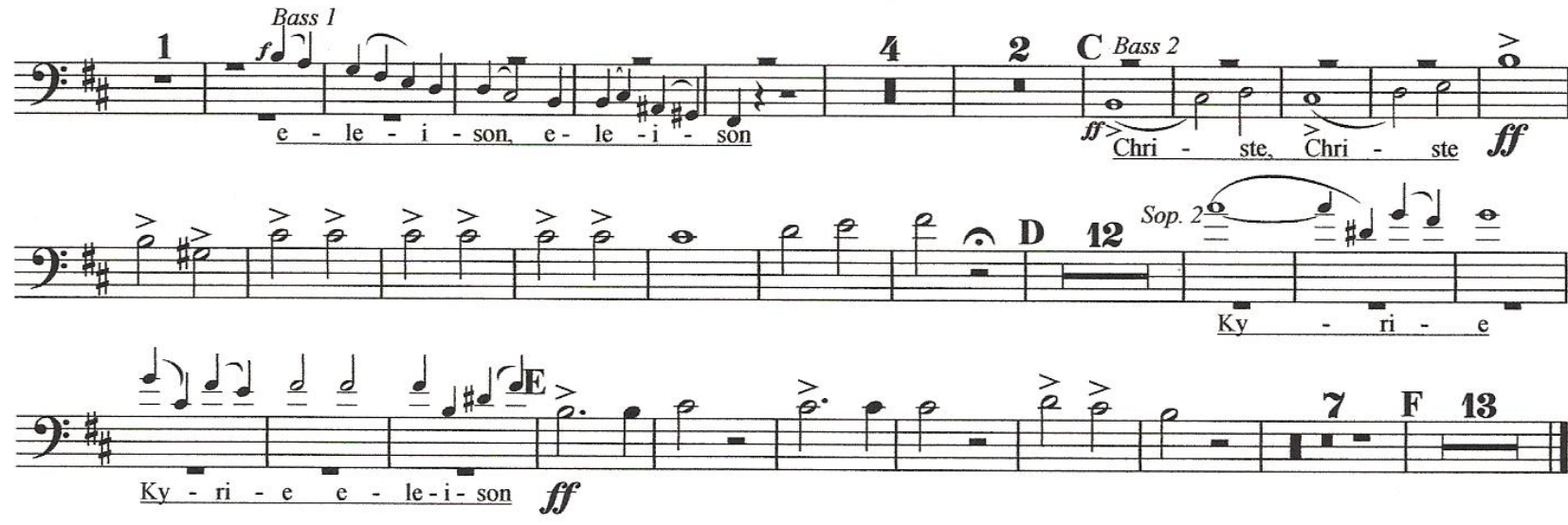

\section{GLORIA}
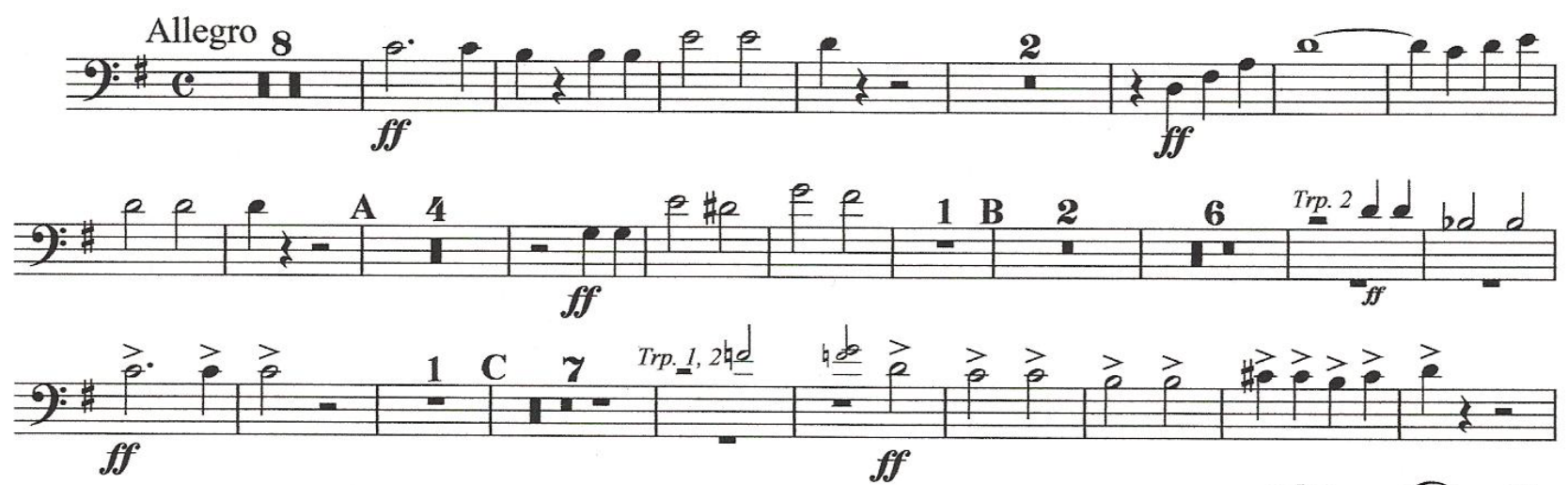

9:

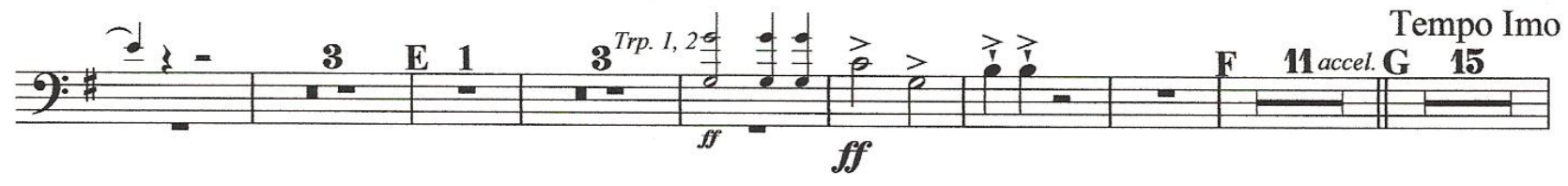


2

Alt-Posaune

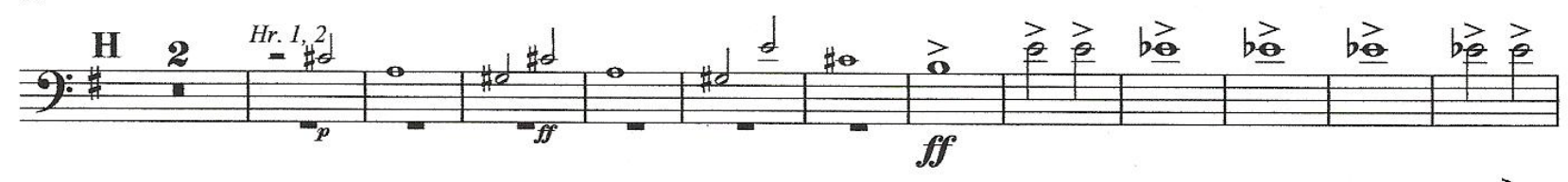

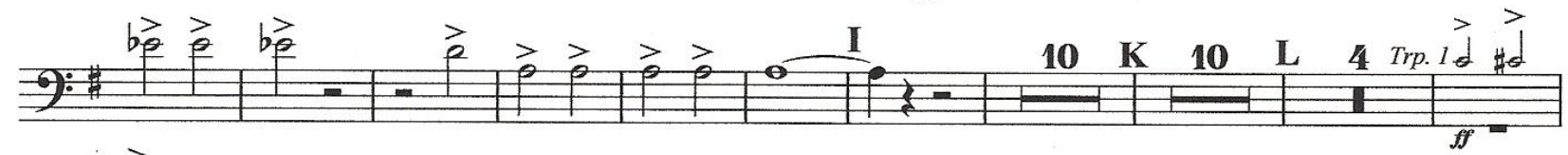

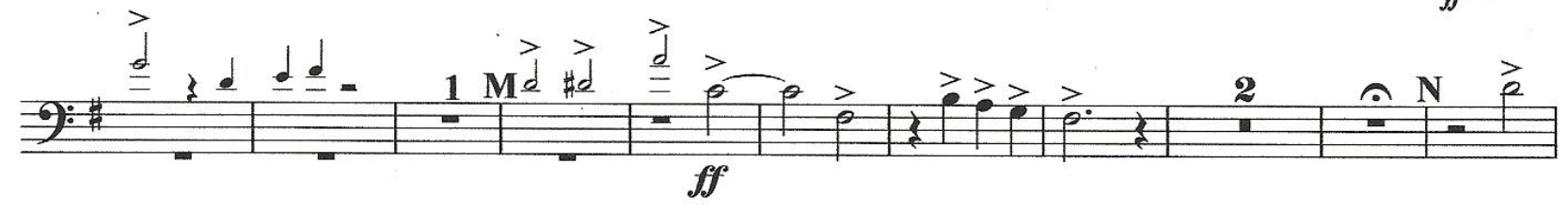

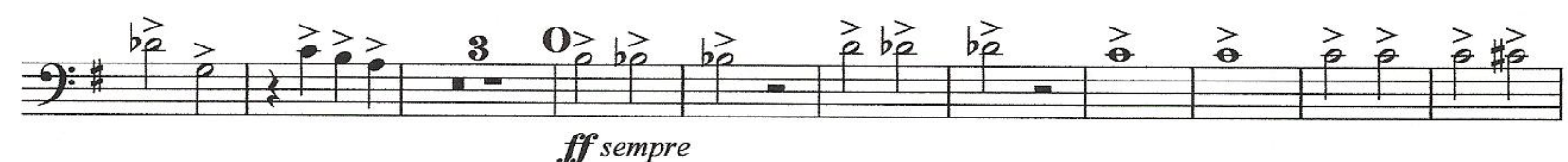

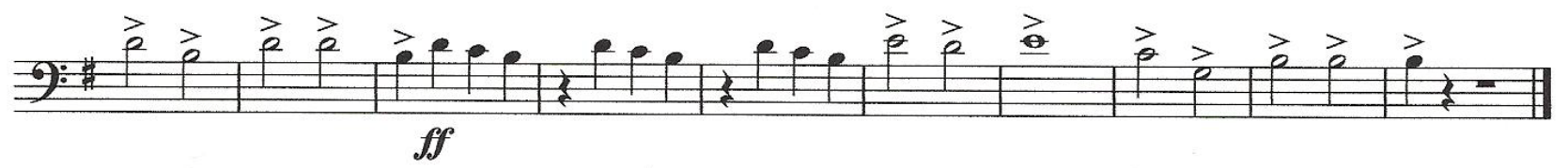

CREDO

Allegro moderato Trp.1,2

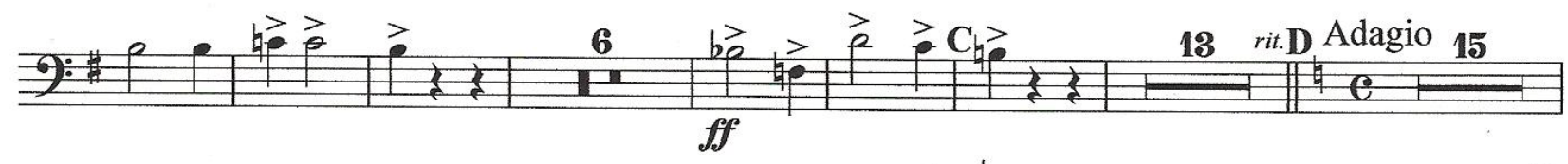

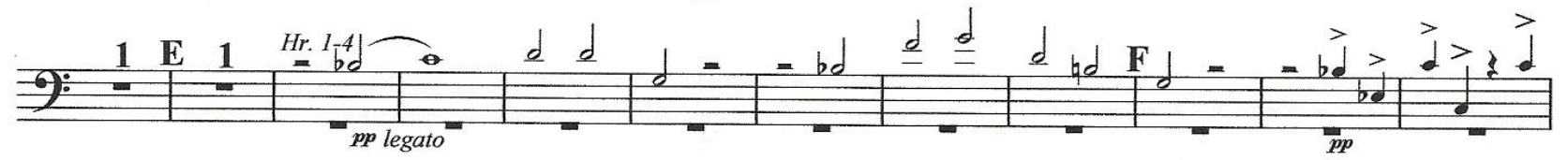

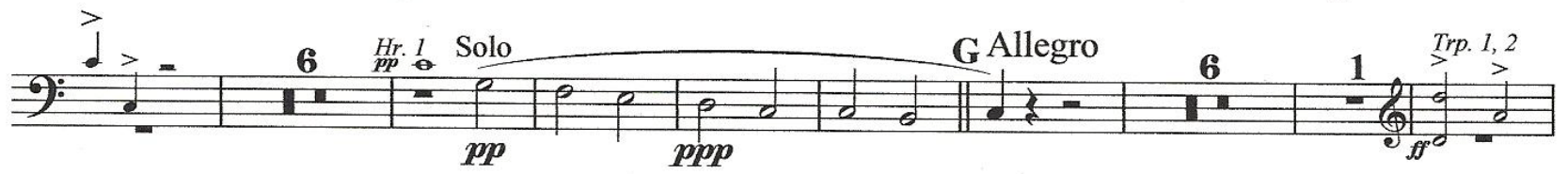

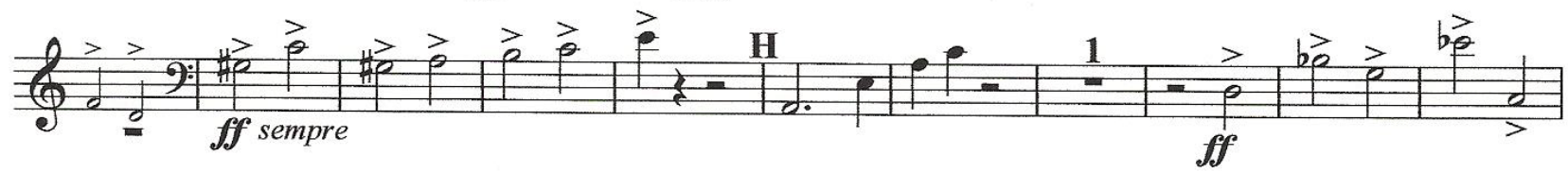

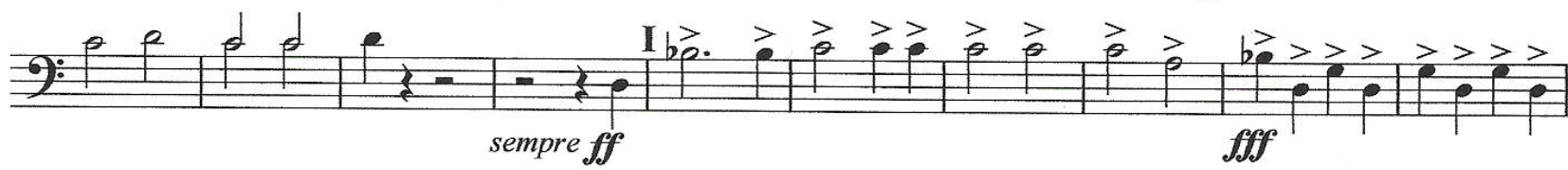




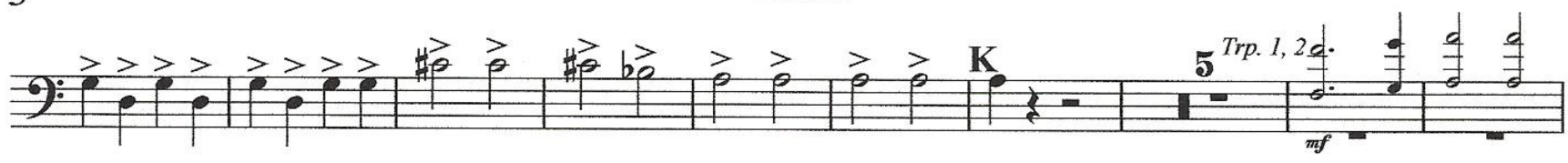

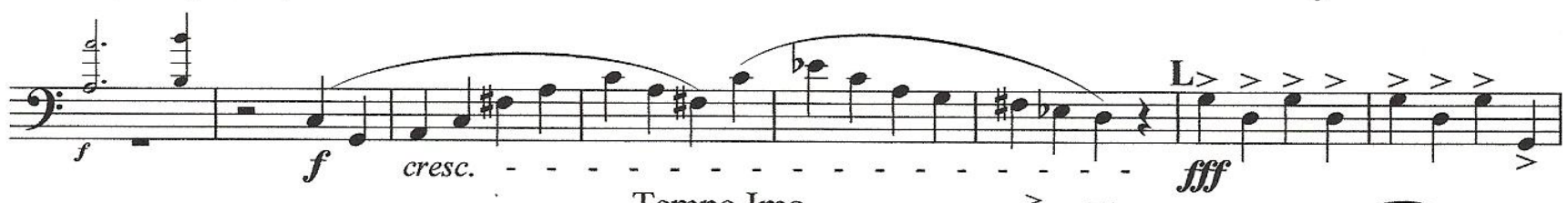



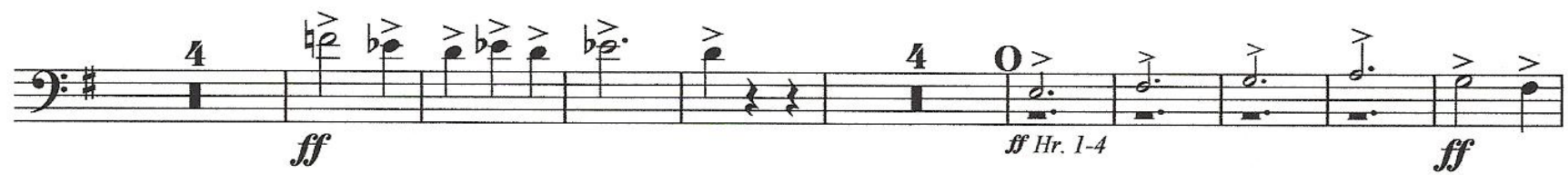

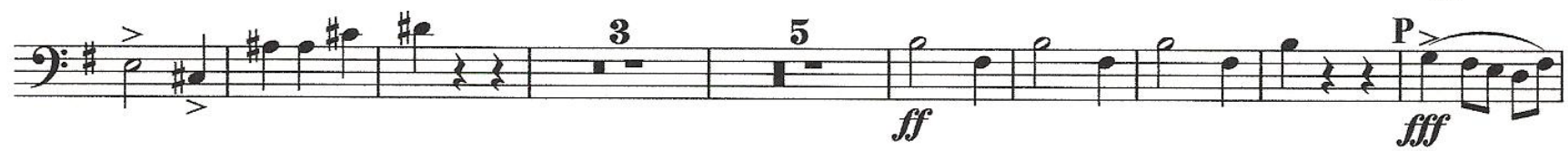
9):

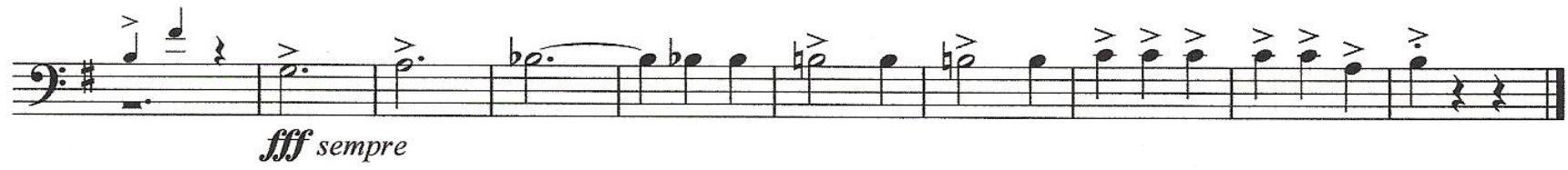

Ruhig; mehr langsam

\section{SANCTUS}
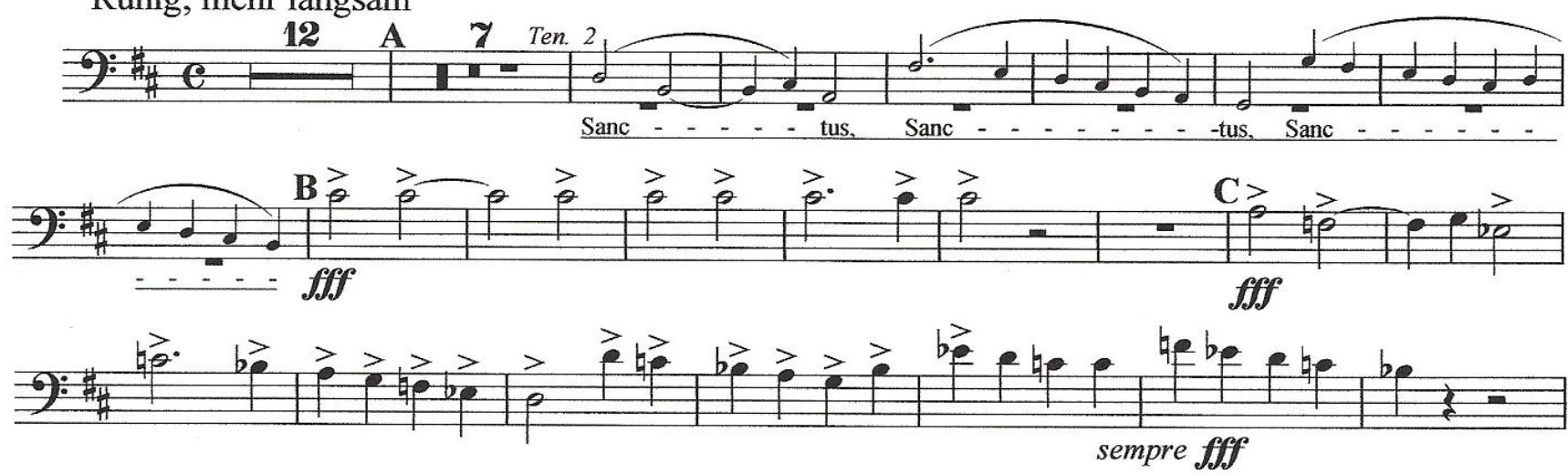

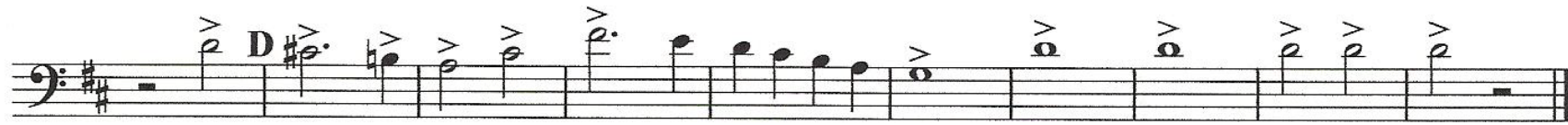


4

\section{BENEDICTUS}

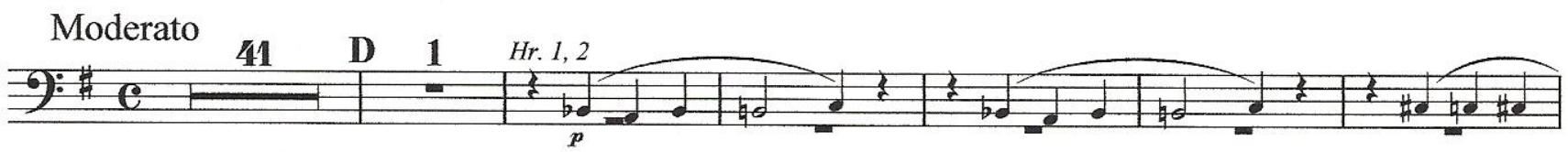


\section{AGNUS}
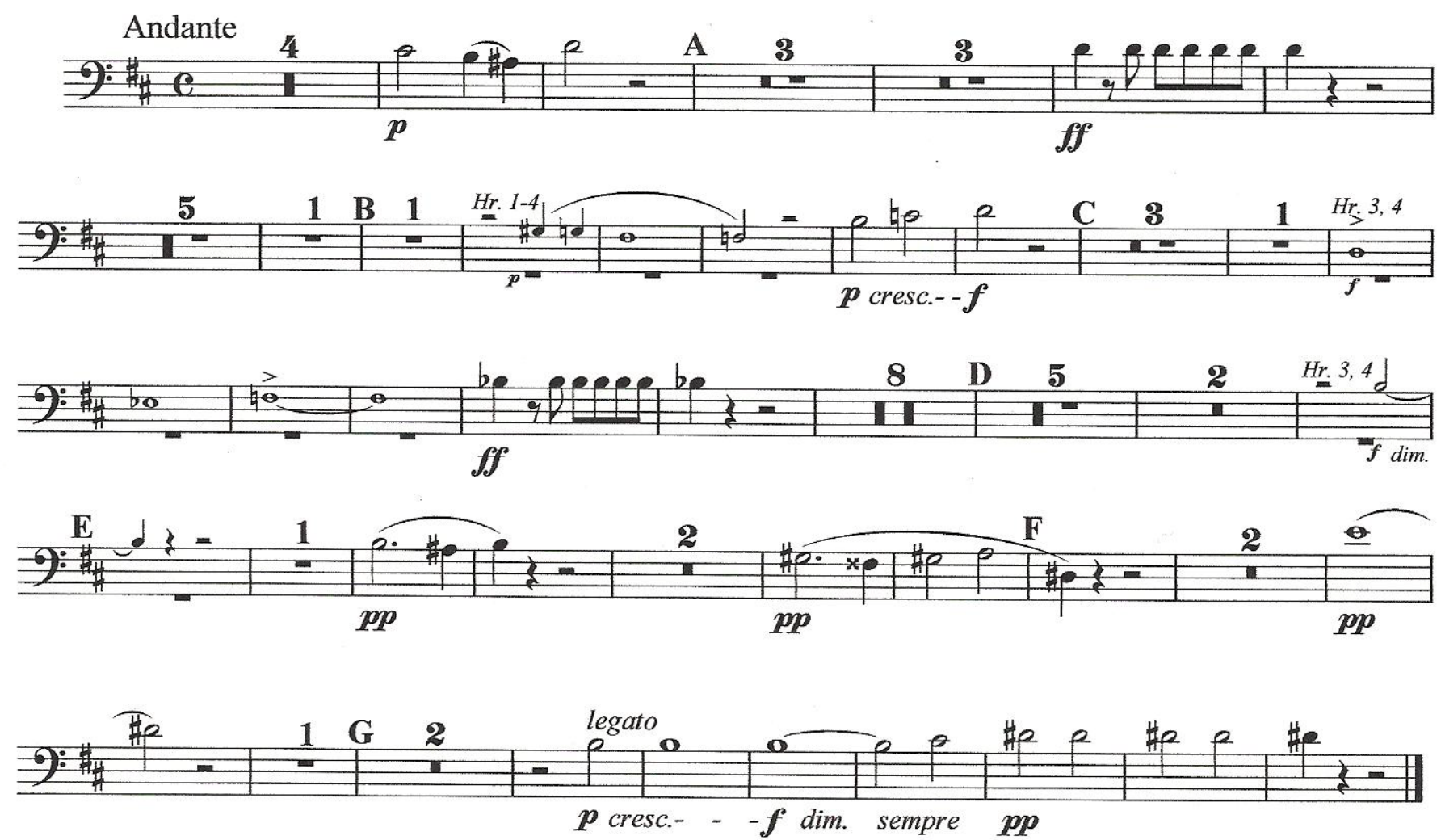


\section{Die Schöpfung}

Altposaune (transposed).

\section{ERSTER TEIL.}

1. Einleitung. (Die Vorstellung des Chaos.)

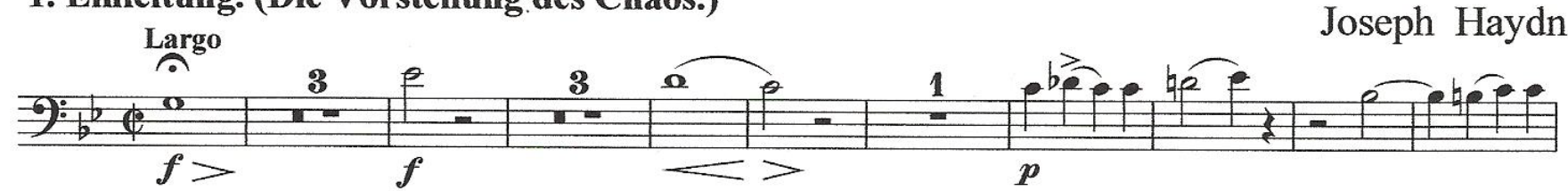

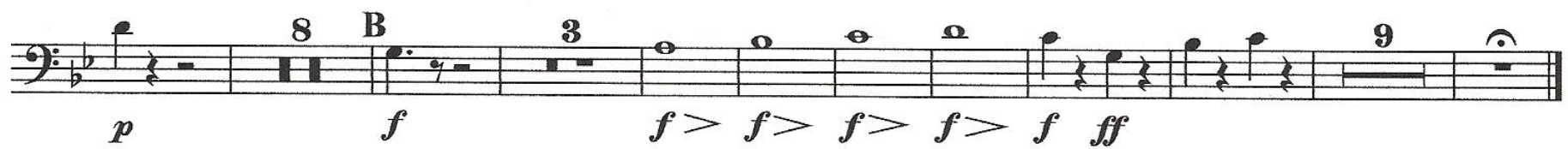

2. Recitativ und Chor.

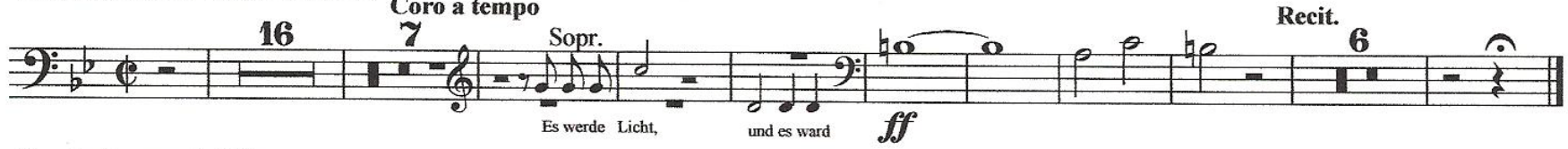

3. Arie und Chor.

Andante

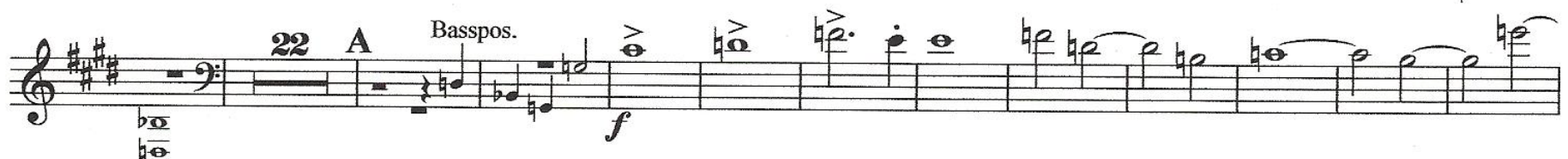

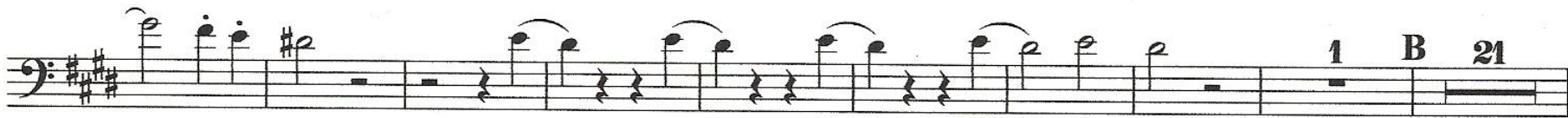

5. Solo mit Chor.

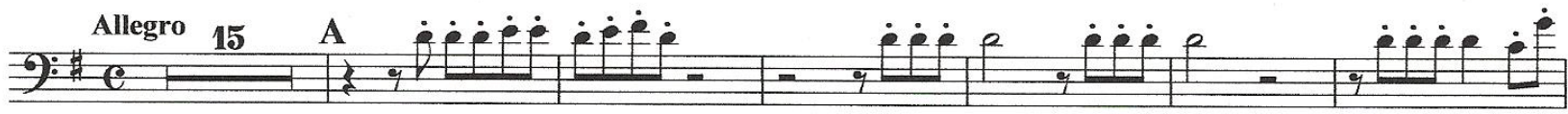

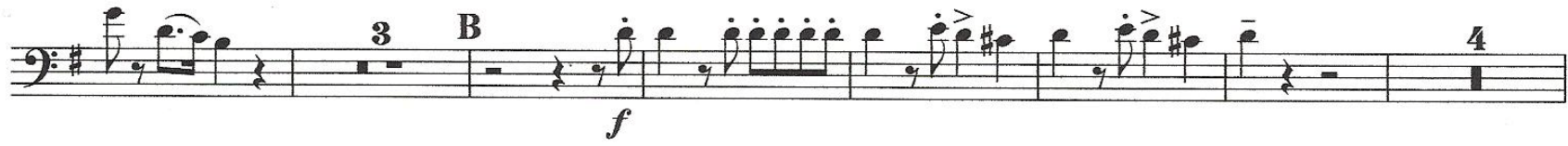

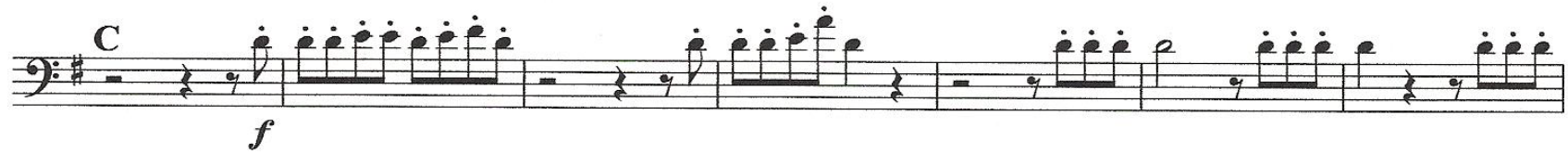

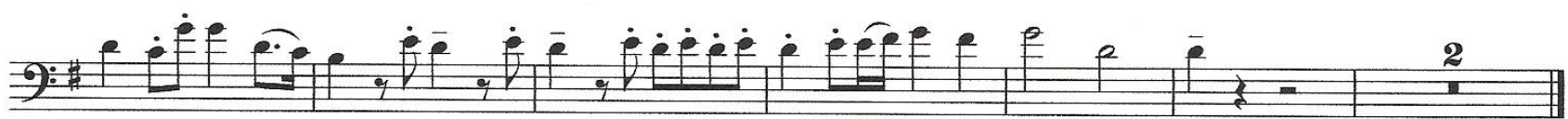

6. Recitativ, 7. Arie, 8. Recitativ, 9. Arie tacet.

10. Recitativ.

Und die himm _lischen Heer_schaa_ren

11. Chor.

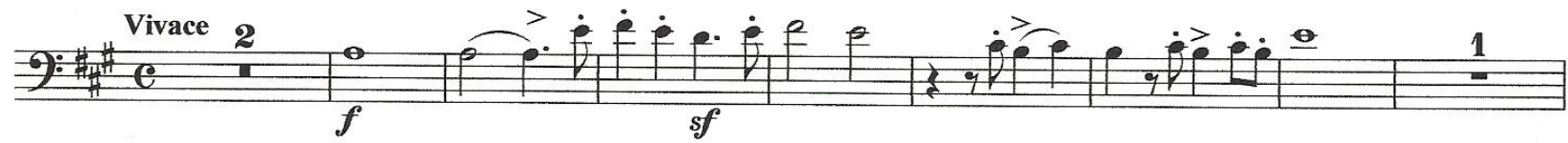

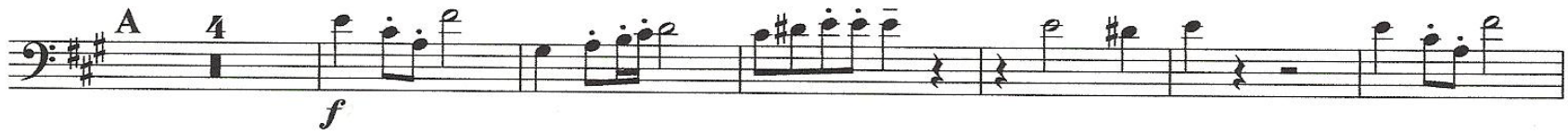

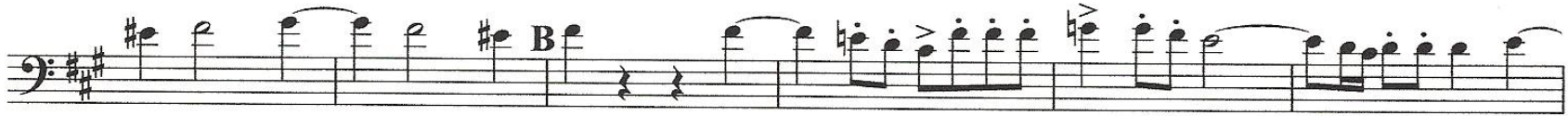
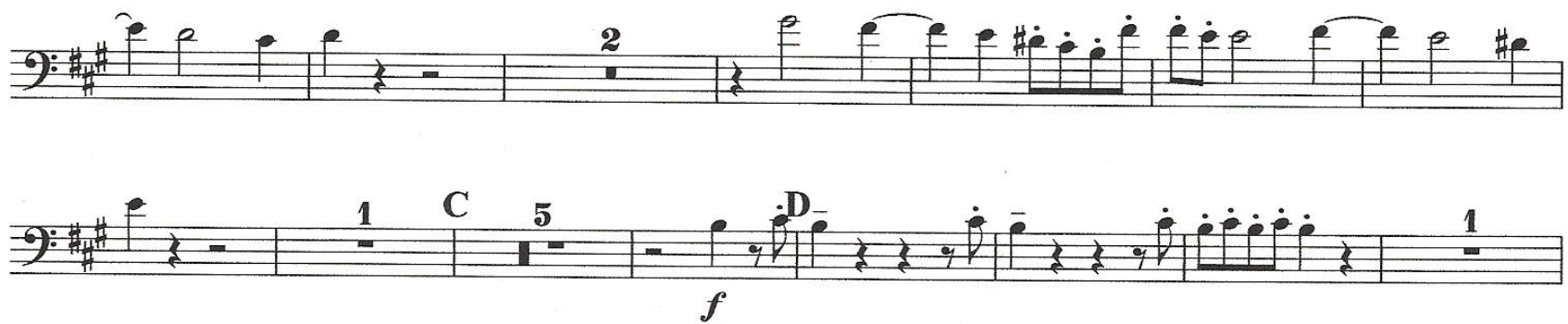
Altposaune (transposed).

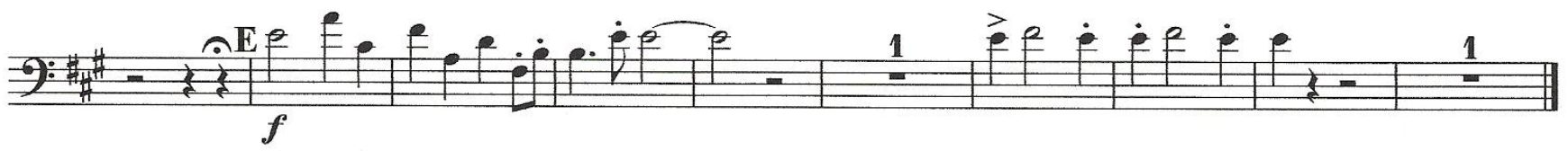

12. Recitativ.

2: 18 Uriel 1

13. Recitativ.

$9:$ Andante 25

9:- Uriel

14. Terzett und Chor.

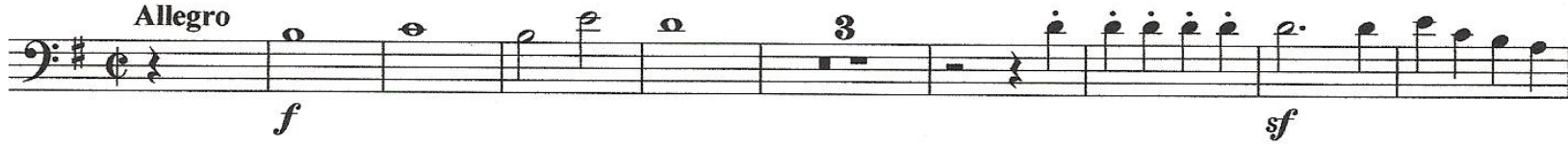
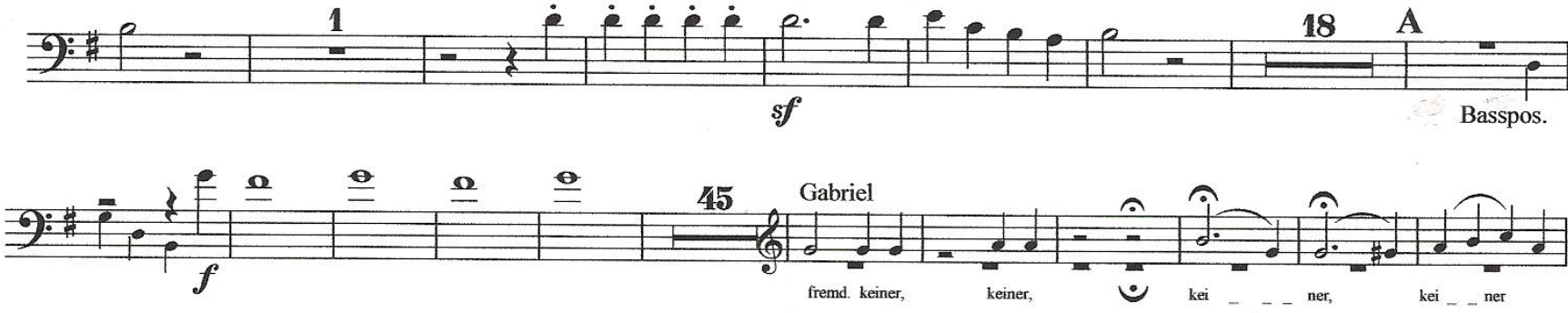

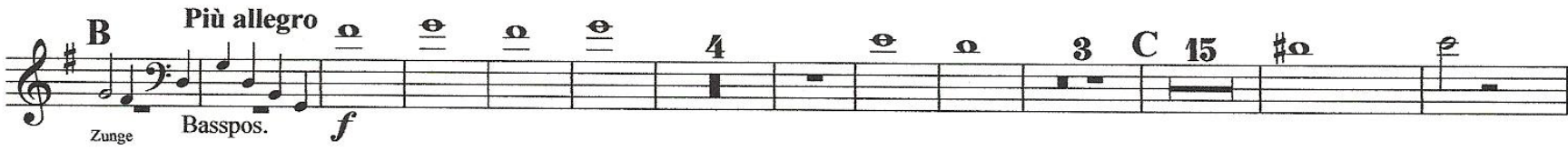

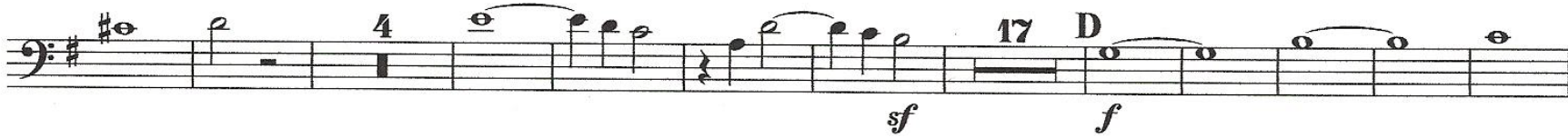

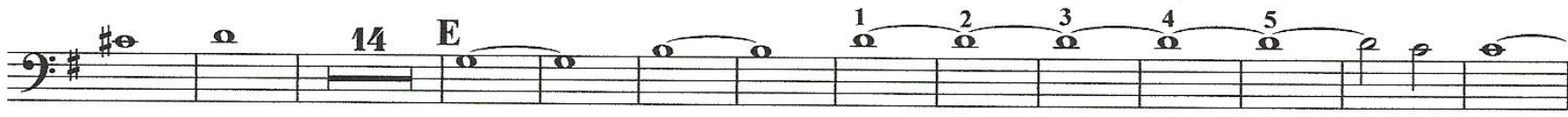

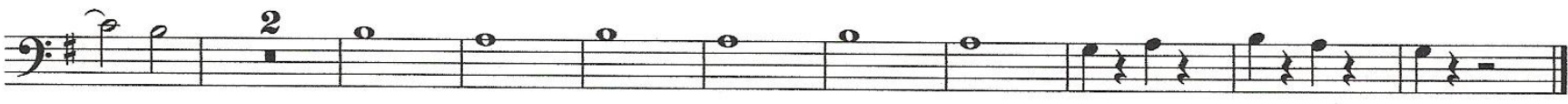


Altposaune (transposed).

ZWEITER TEIL.

15. Recitativ, 16. Arie, 17. Recitativ, 18. Recitativ tacet

19. Terzett und Chor.

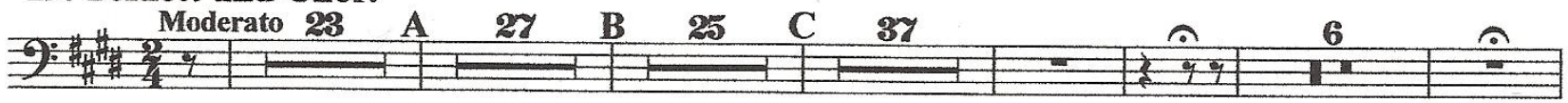

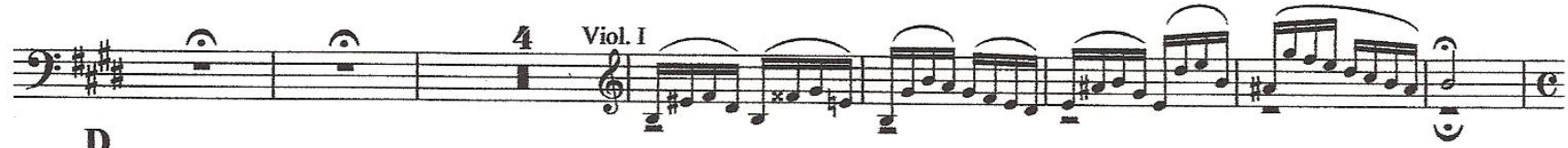

(1)

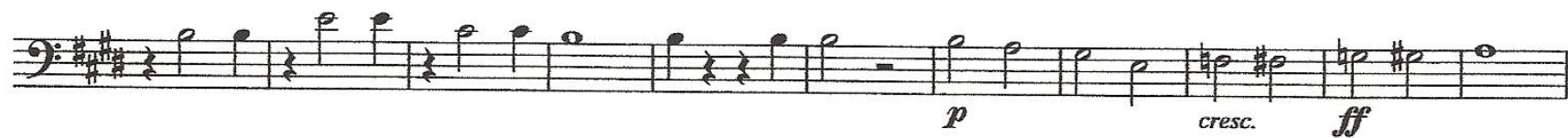

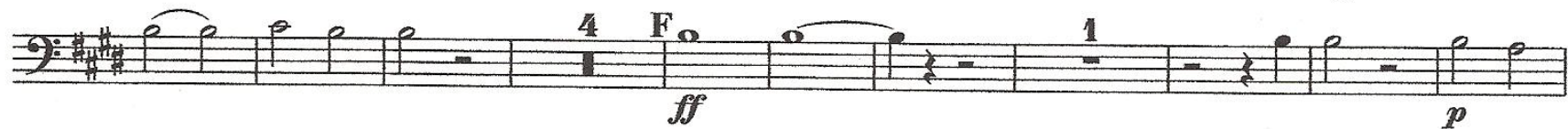

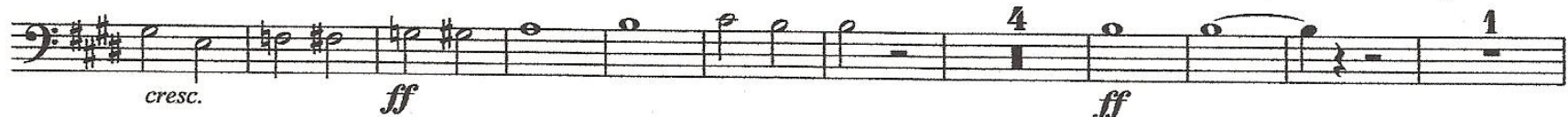

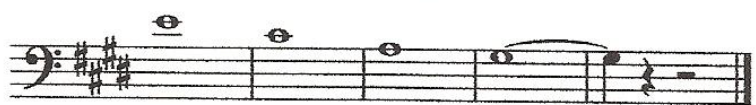

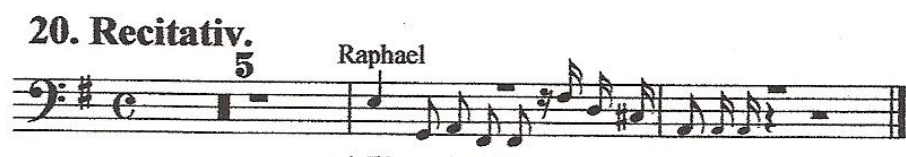

21. Recitativ.

und Thiere der Erde nach ihren Gattungen

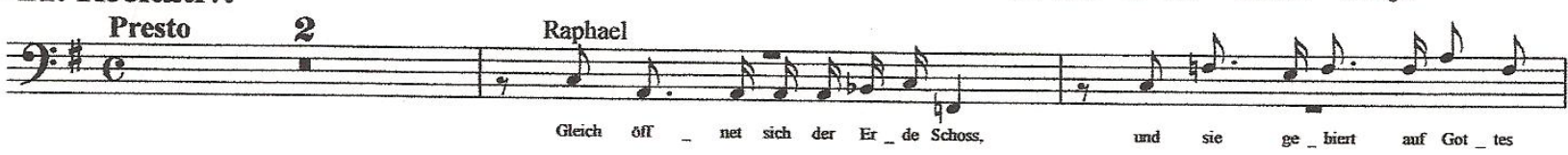

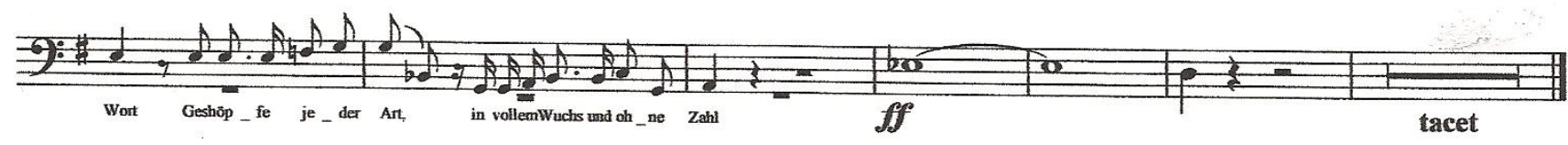

22. Arie, 23. Recitativ, 24. Arie tacet.

25. Recitativ.

26. Chor und Terzett.

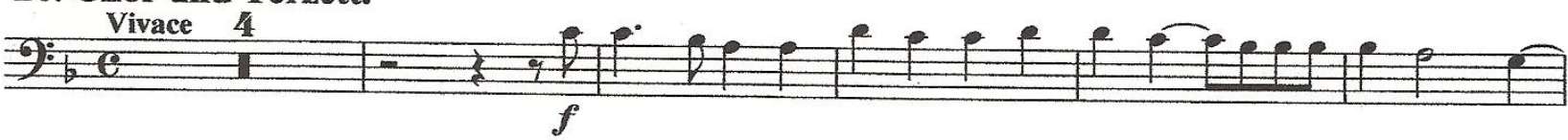

9: 


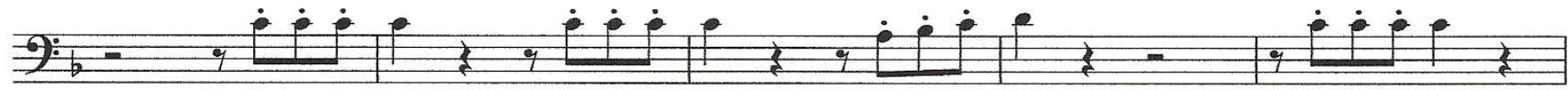

Fु.

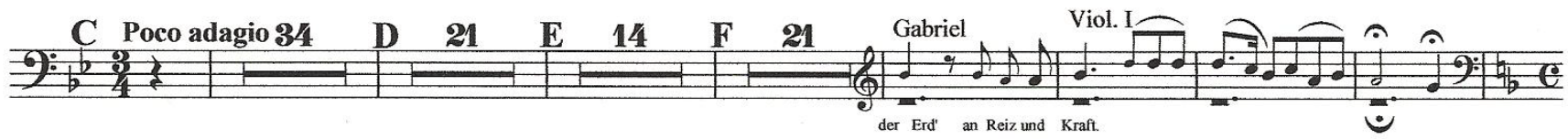

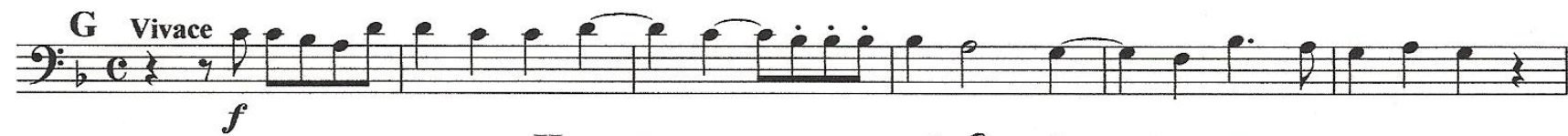

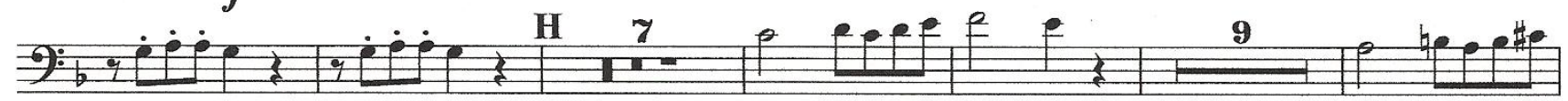

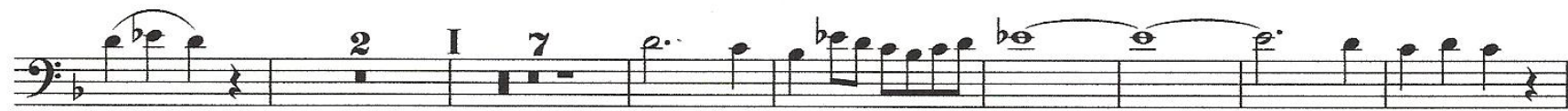

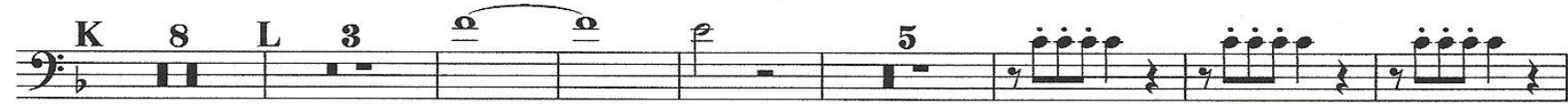

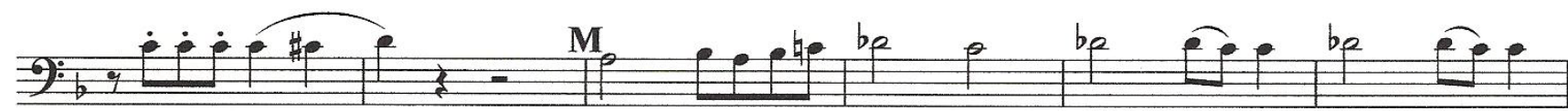

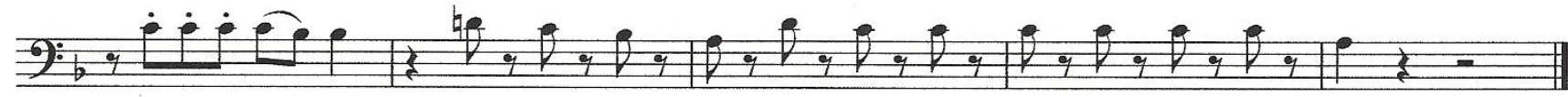

\section{DRITTER TEIL.}

28. Duett mit Chor.

27. Recitativ tacet.

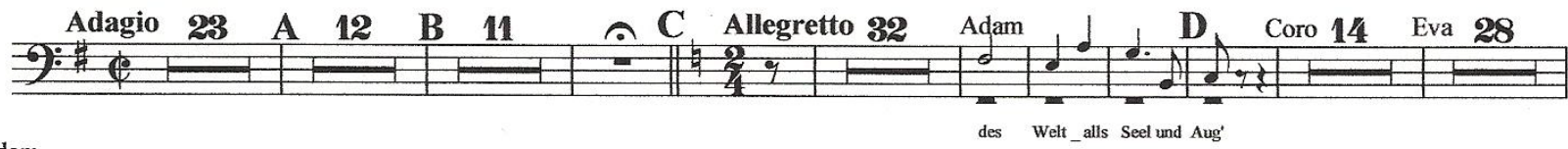

9):

9:: Eva 28 Adam 18

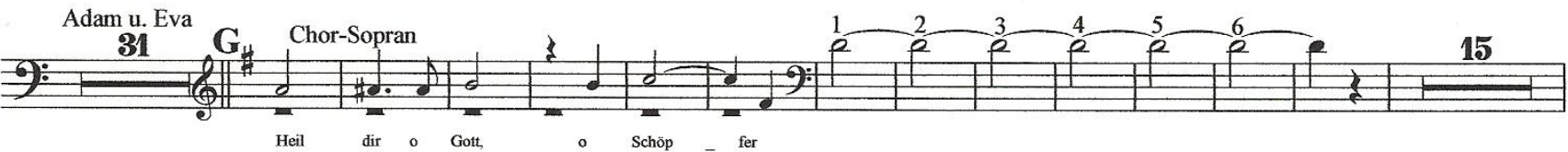


6

Altposaune (transposed).

牙:

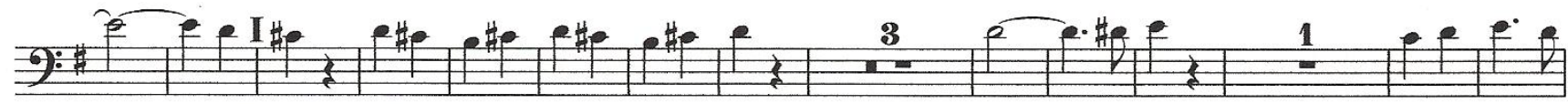

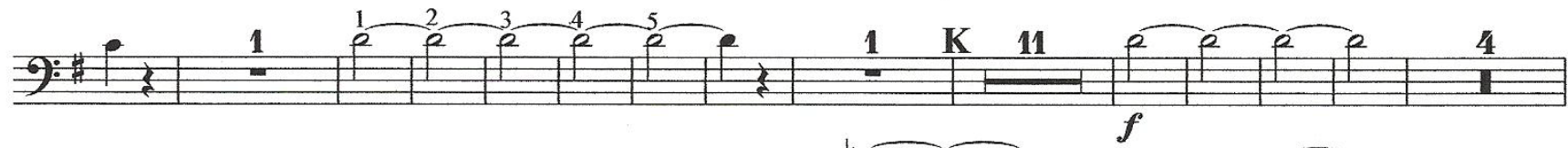

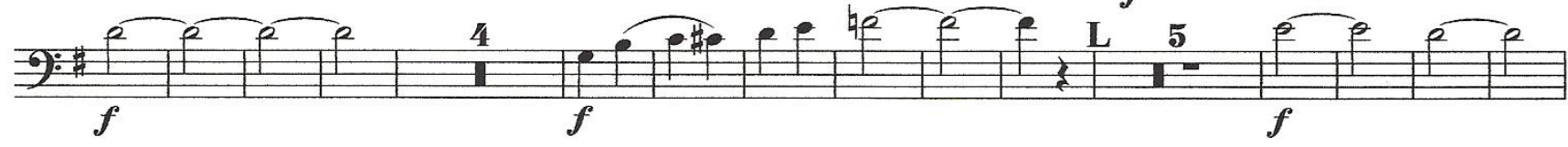

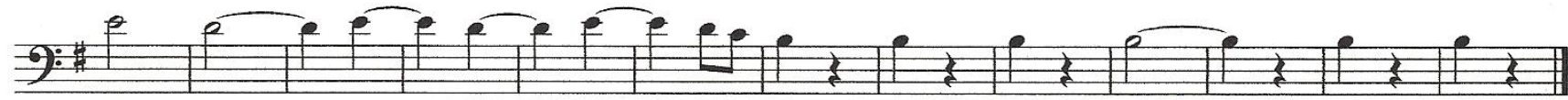
29. Recitativ, 30. Duett. tacet

31. Recitativ.

9:: (2)

32. Schlusschor.

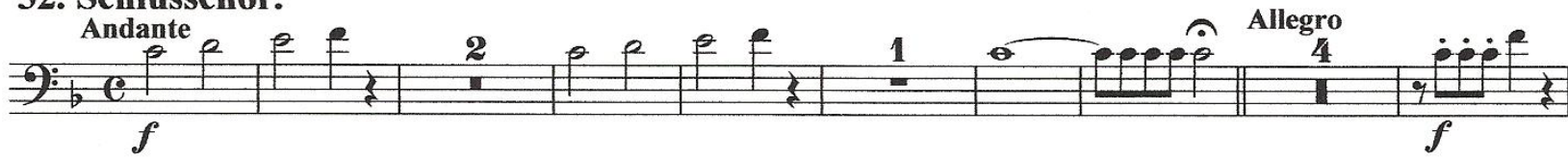

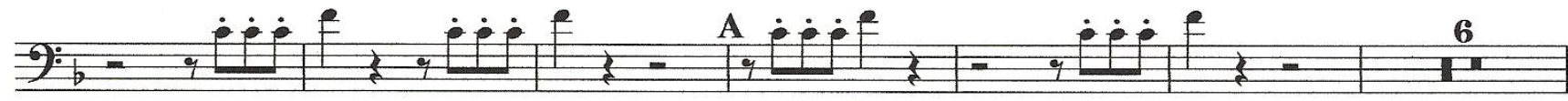

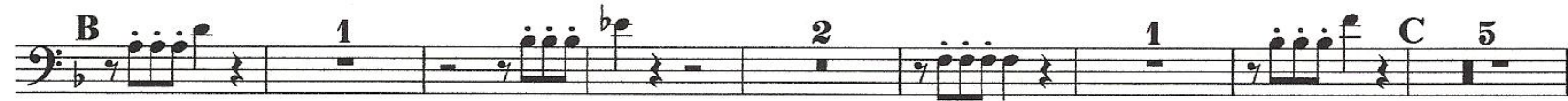



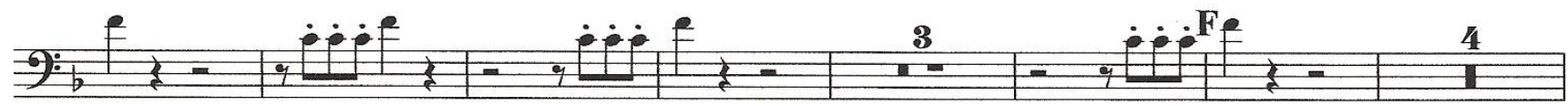

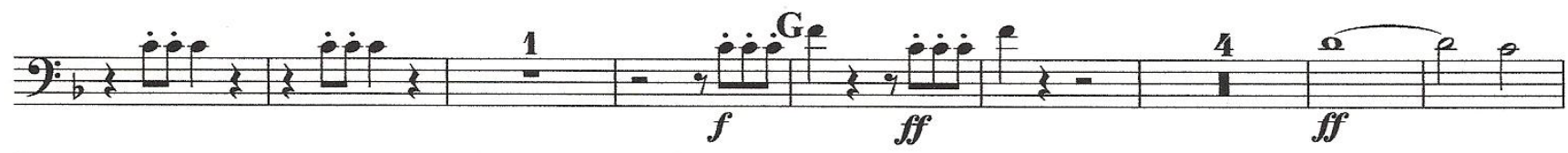

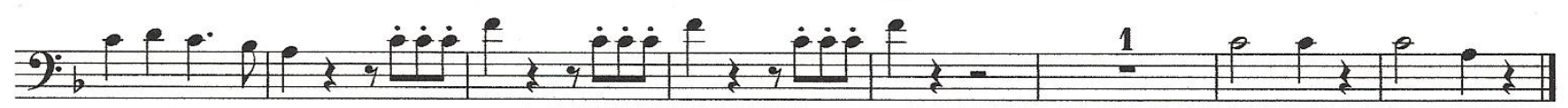




\title{
Fünfte (Reformations-) Symphonie.
}

\author{
TROMBONE ALTO (transposed).
}

Felix Mendelssohn Bartholdy, Op. 107.

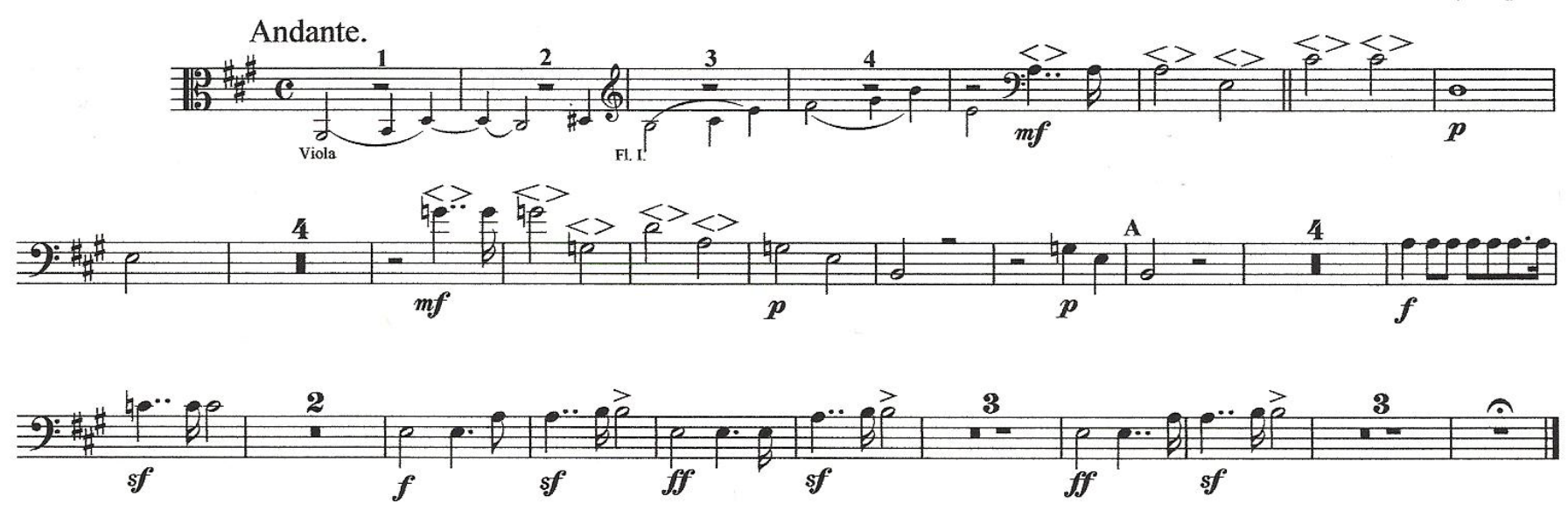

Allegro con fuoco und Allegro vivace tacet.

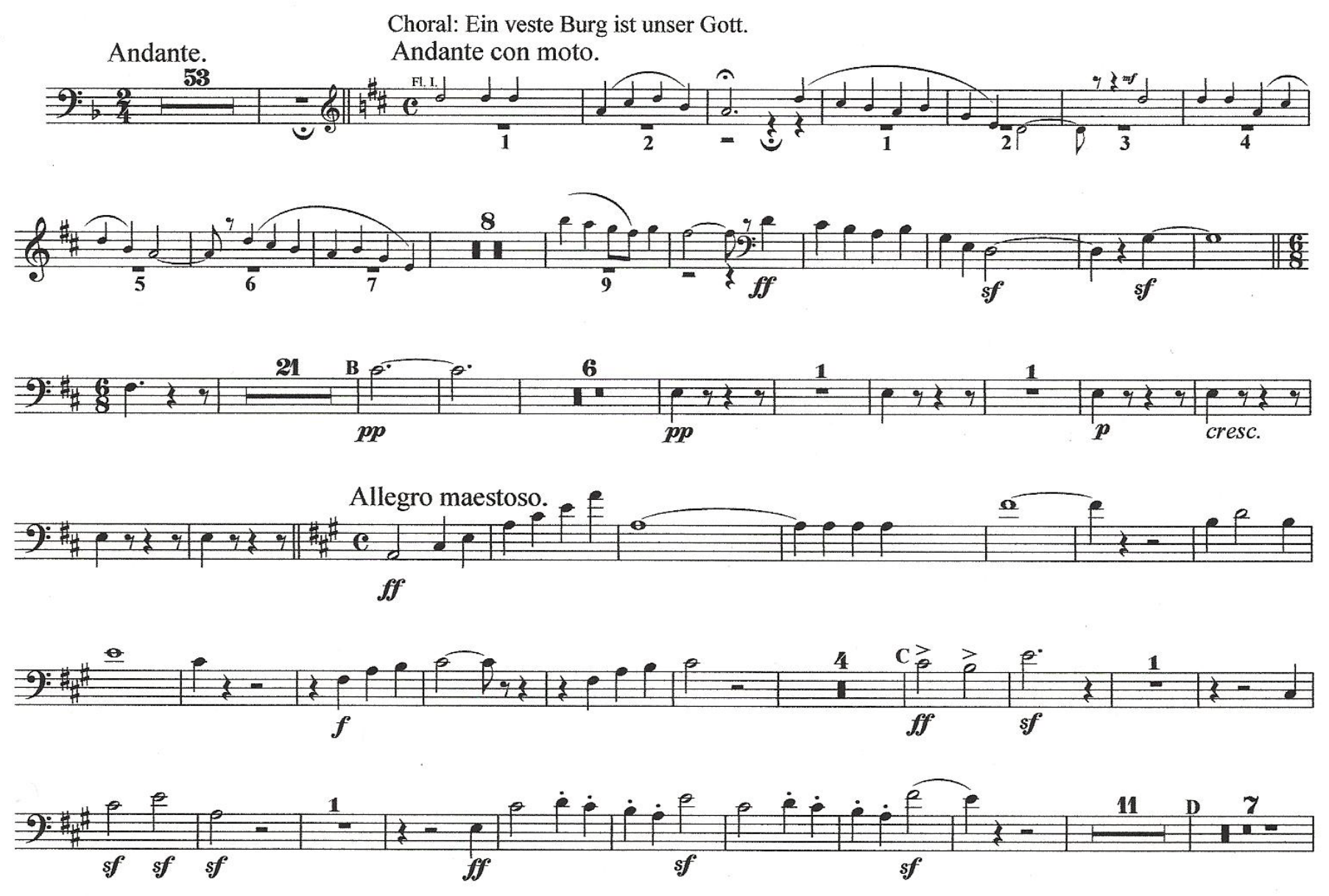


2

TROMBONE ALTO.


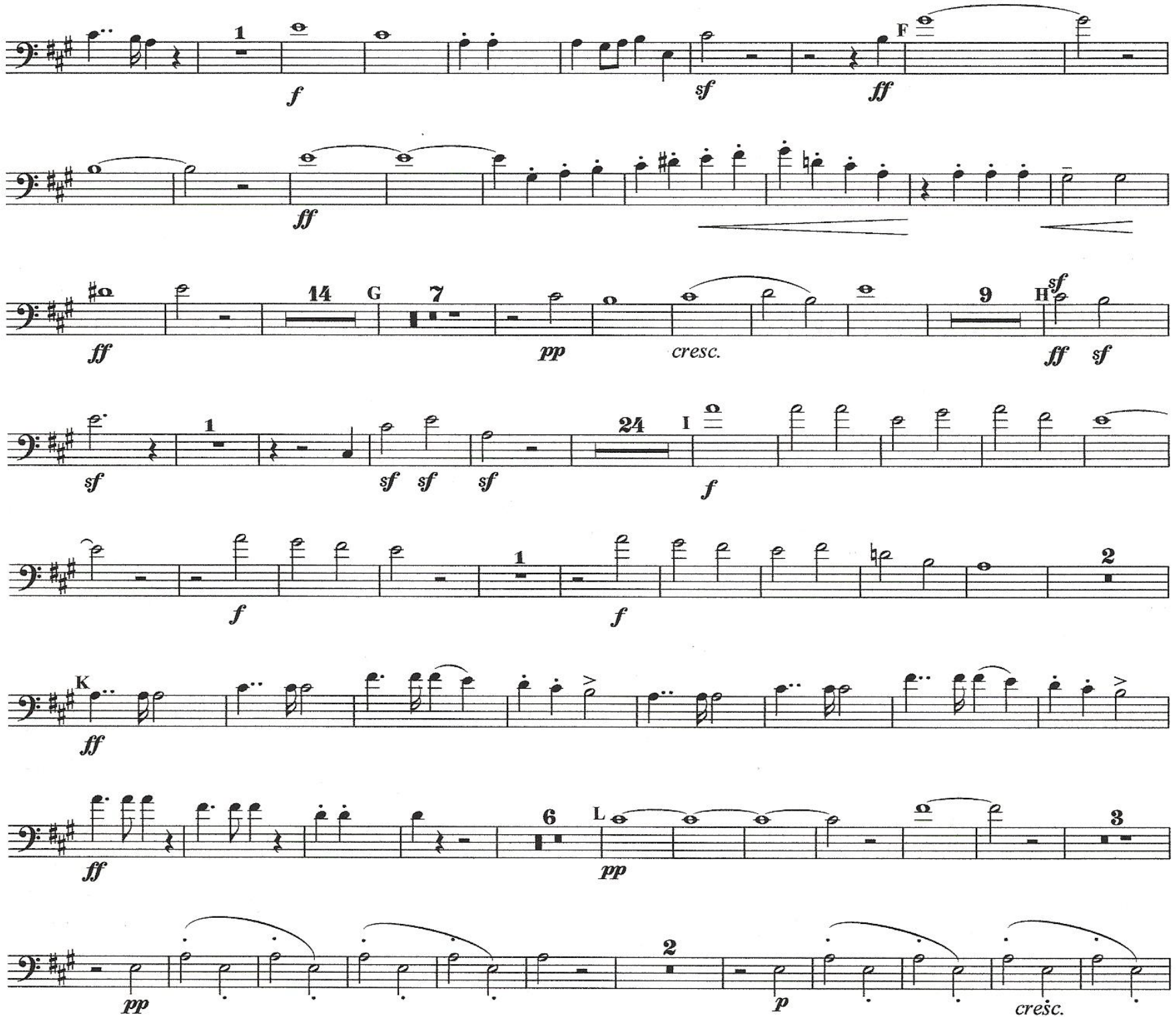

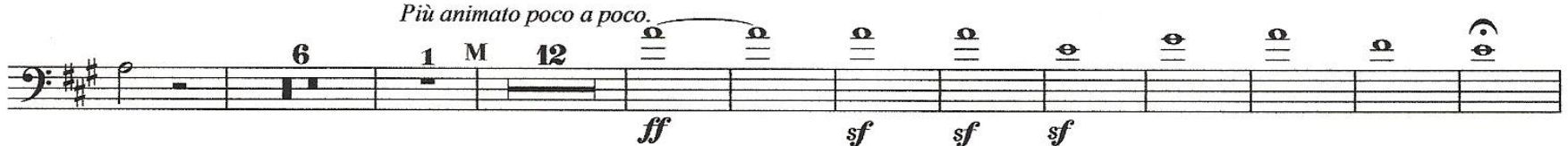

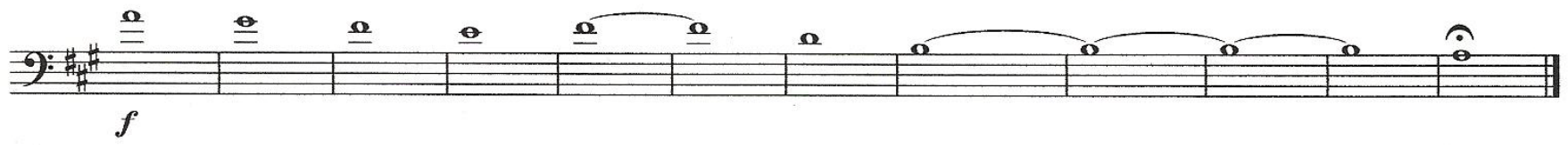


TROMBONE ALTO (TRANSPOSED).

1. Requiem.

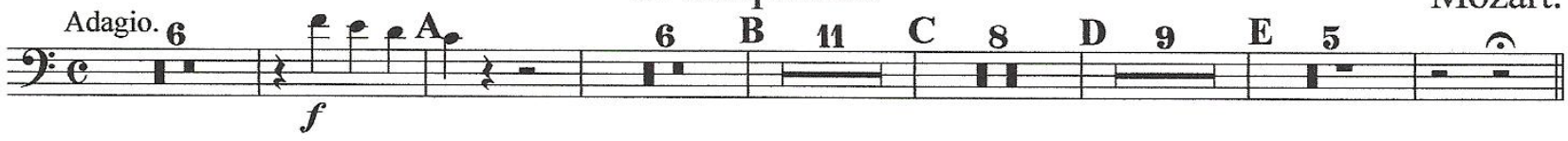

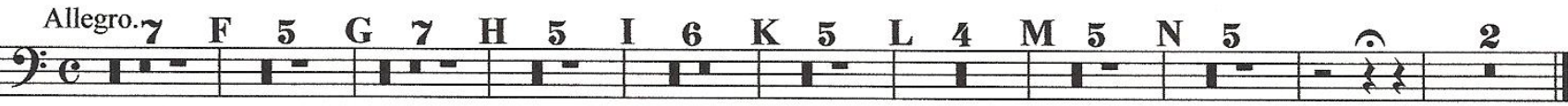

2. Dies irae.

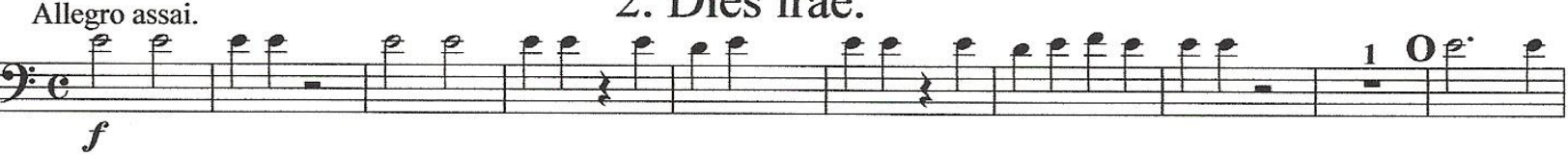

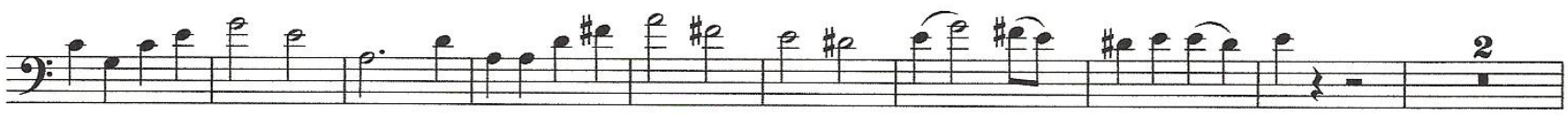

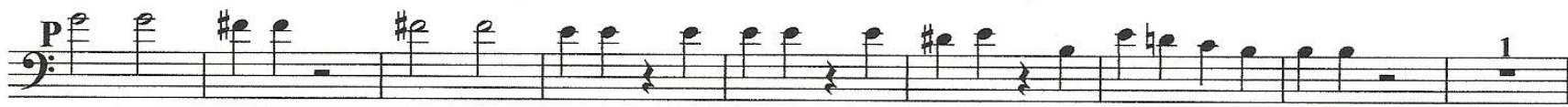

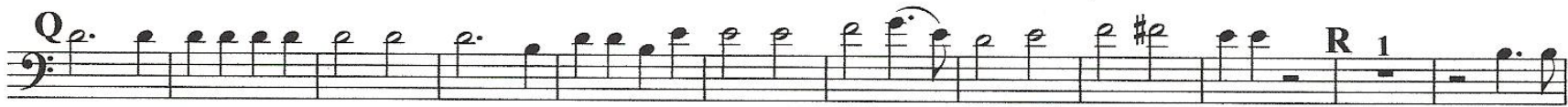

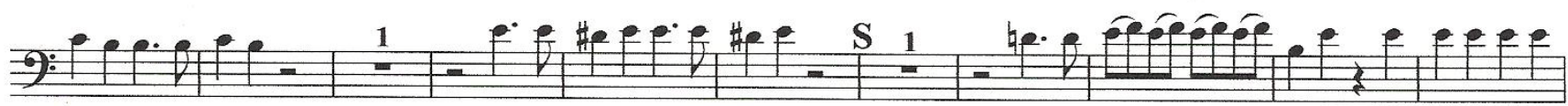

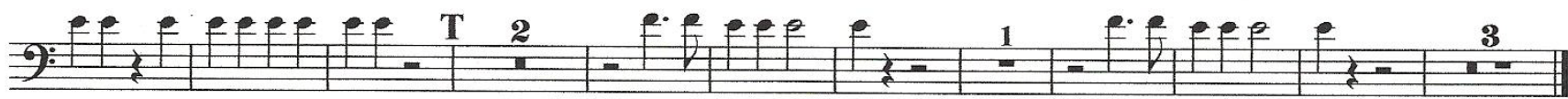

3. Tuba mirum tacet

4. Rex tremendae.

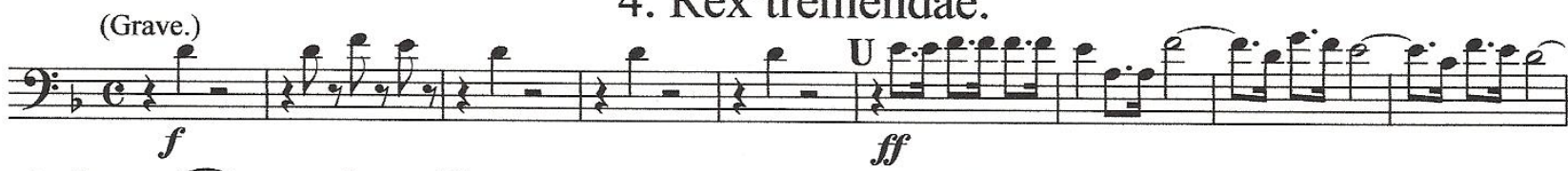

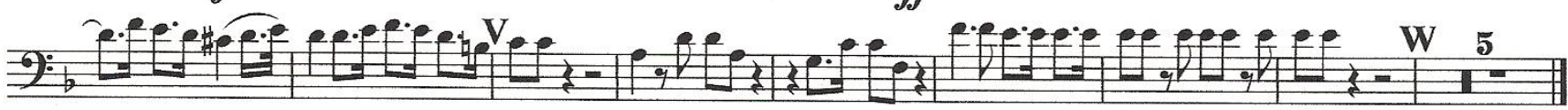

5. Recordare tacet.

6 Confutatis.

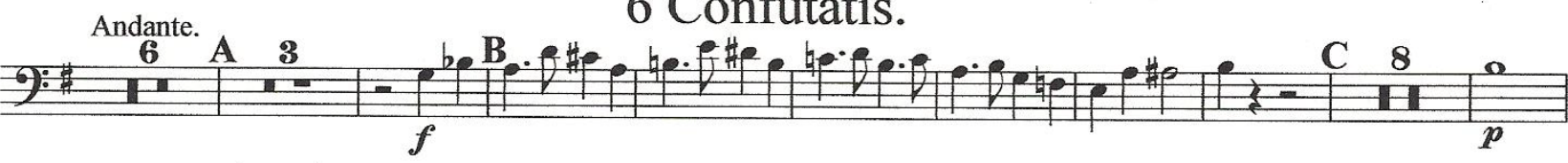
9: DHe a 
TROMBONE ALTO (TRANSPOSED).

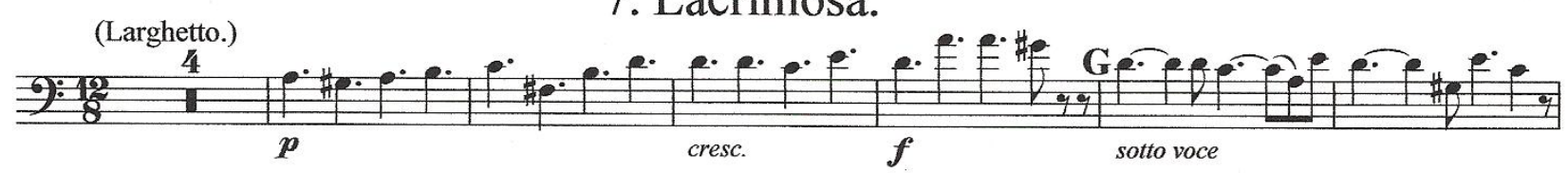

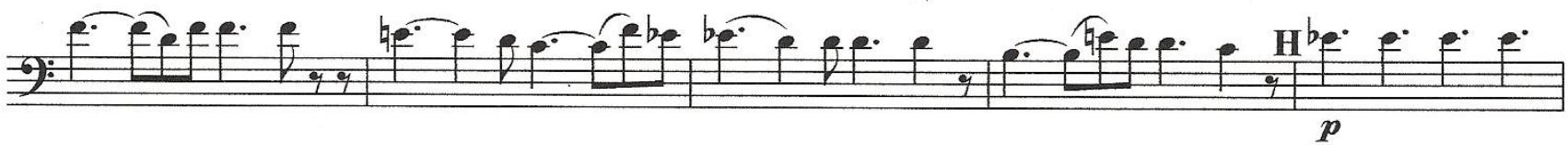
9 g.0. 8. Domine Jesu.

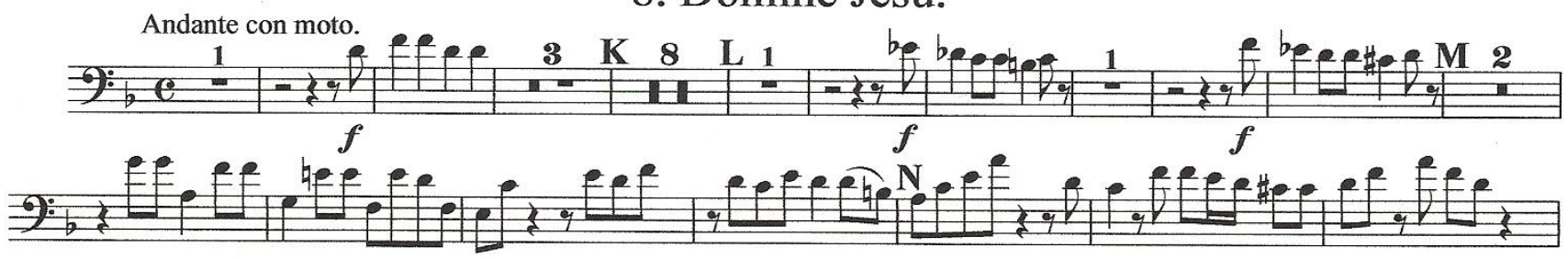

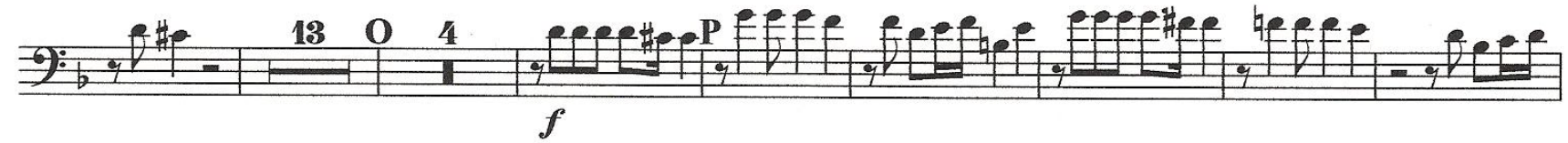

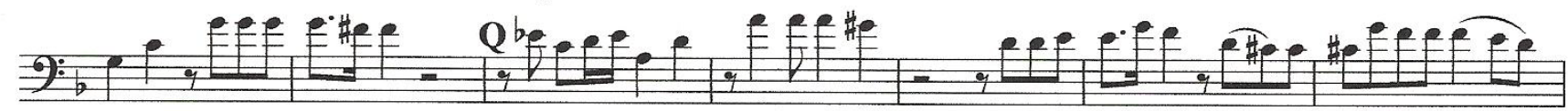

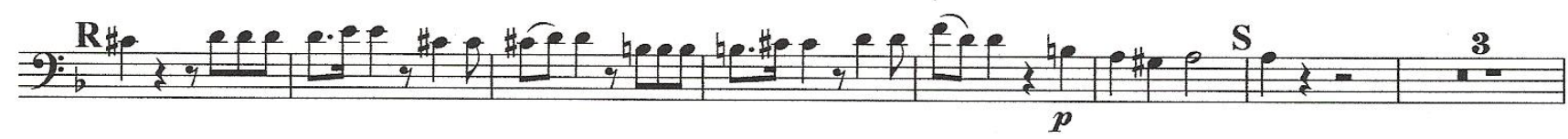

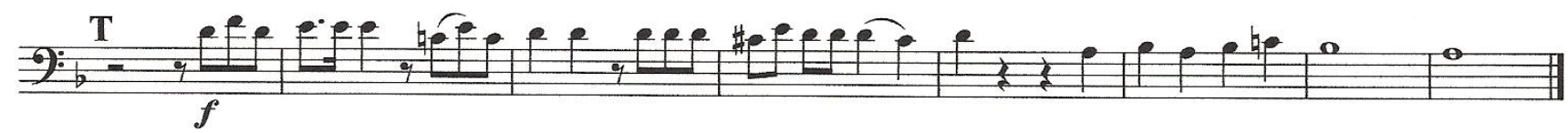
9. Hostias.

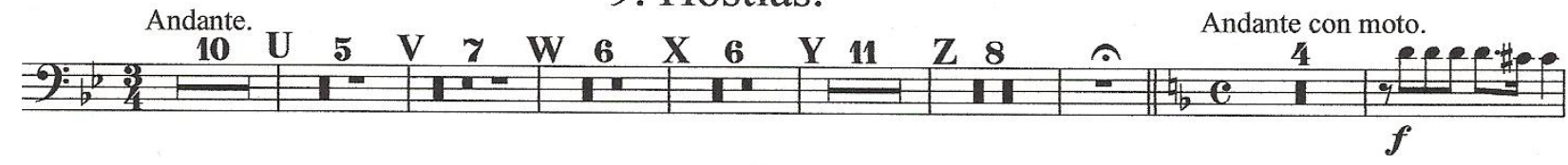

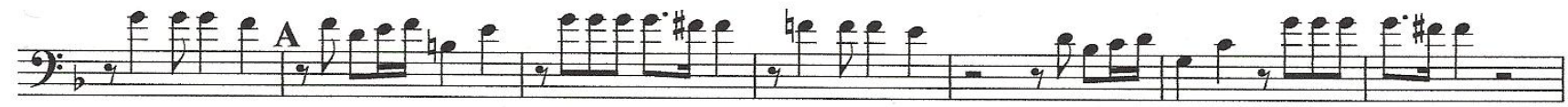


TROMBONE ALTO (TRANSPOSED).

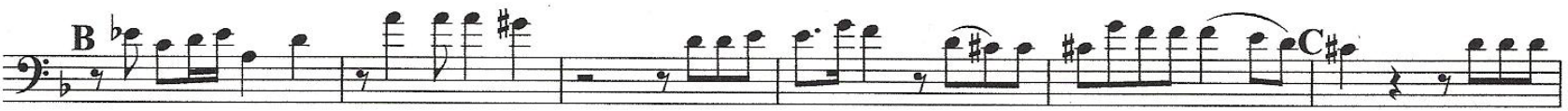

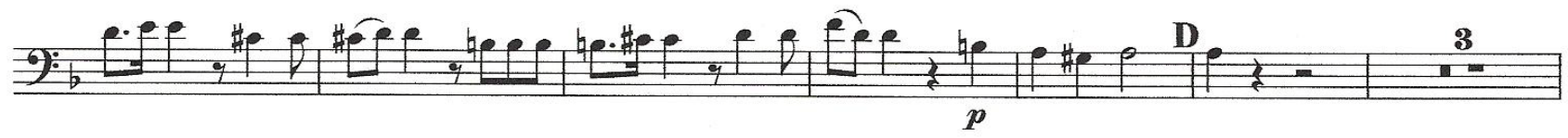

E 10. Sanctus tacet.

11. Benedictus.

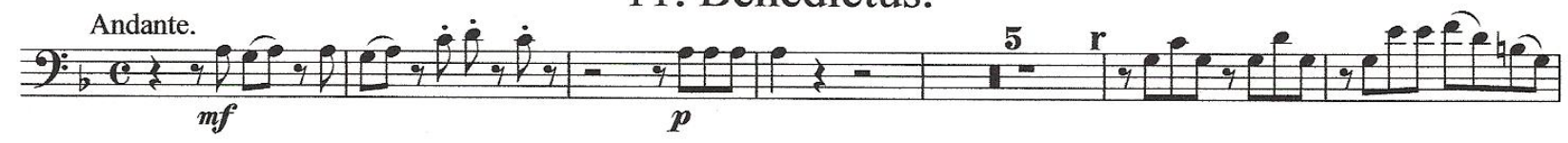

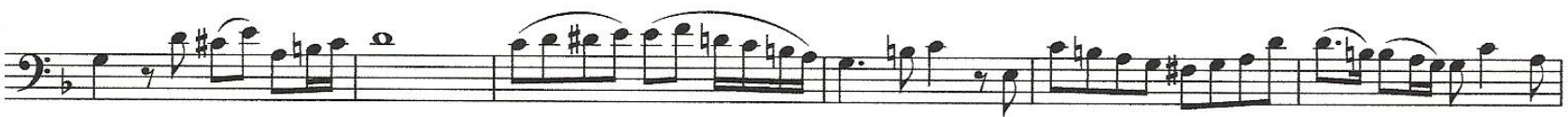
20

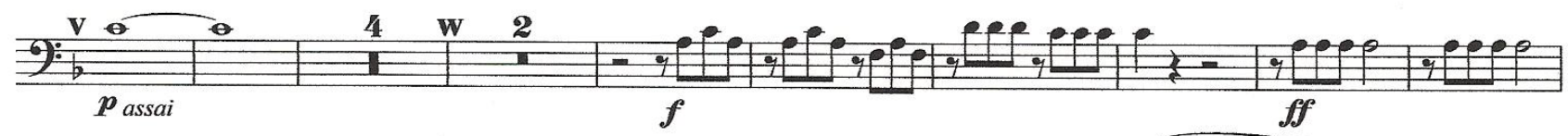
Allegro 3 gicen 12. Agnus Dei.

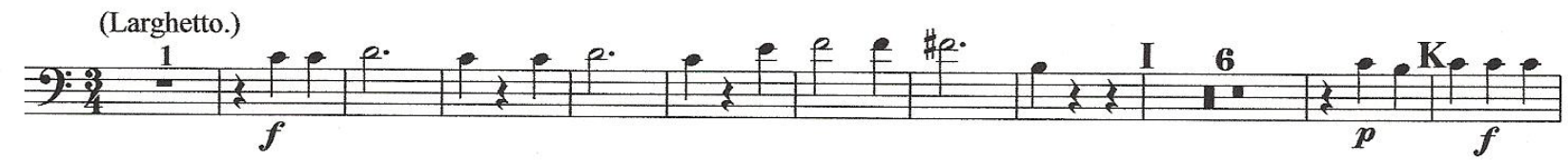
年

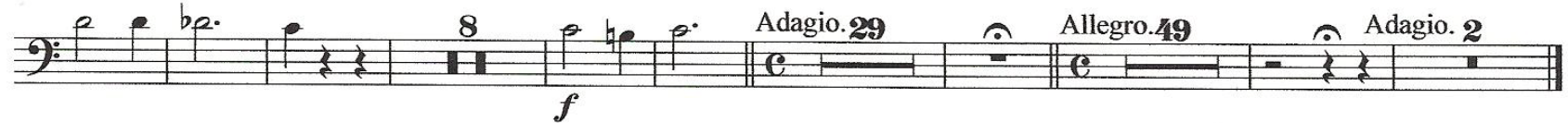




\title{
"Great" Symphony in C Major (No. 9)
}

\author{
TROMBONE I (ALTO)
}

(Transposed)

F. Schubert.

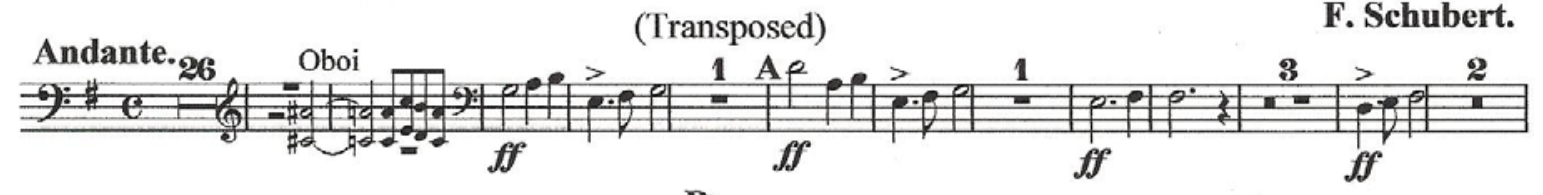

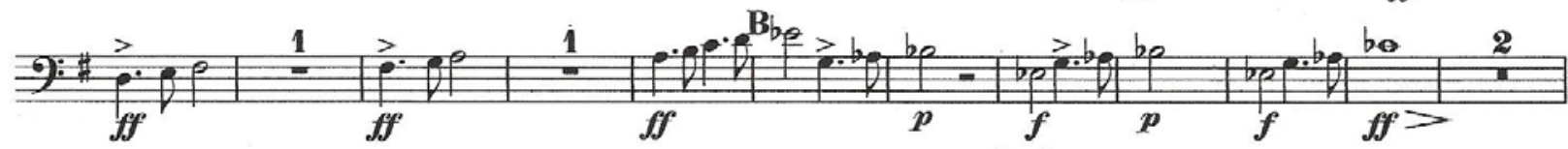

$\frac{70 \text { - } 13}{p}$

Allegro, ma non troppo

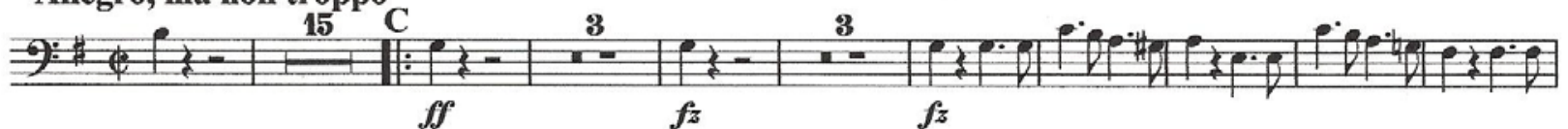

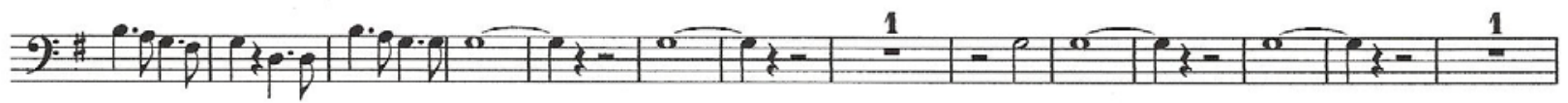

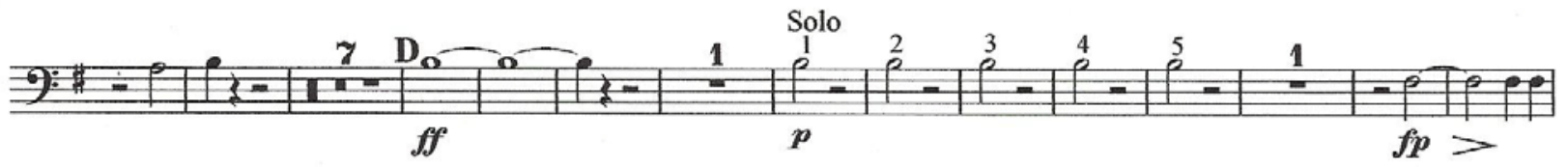

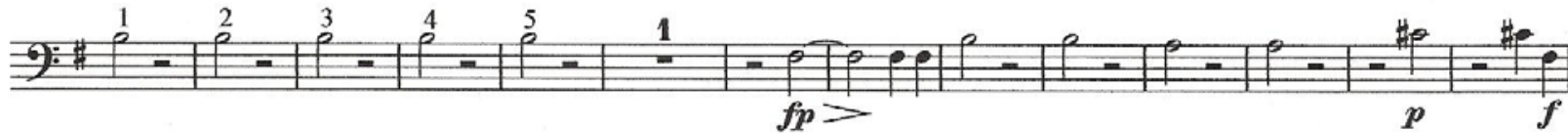

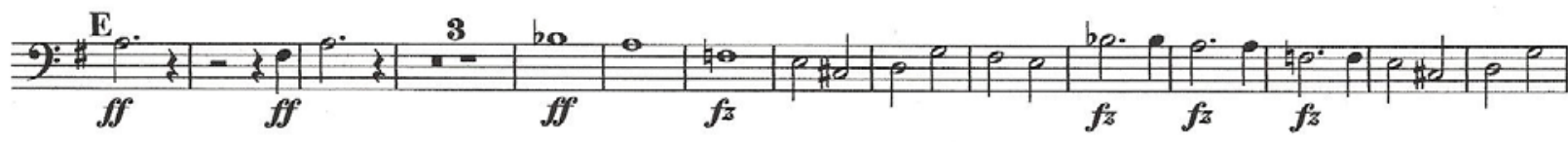

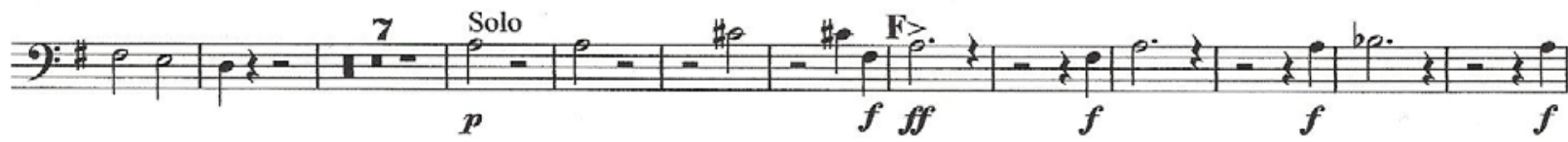



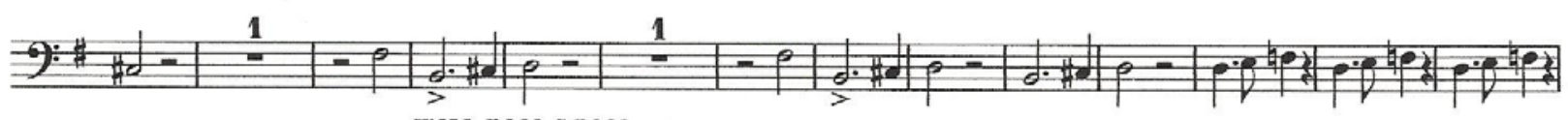

9:.

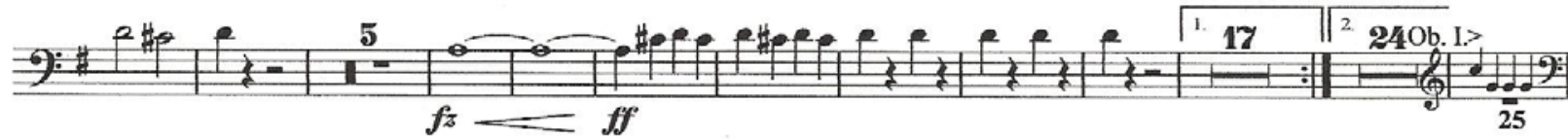


2 TROMBONE I (ALTO)

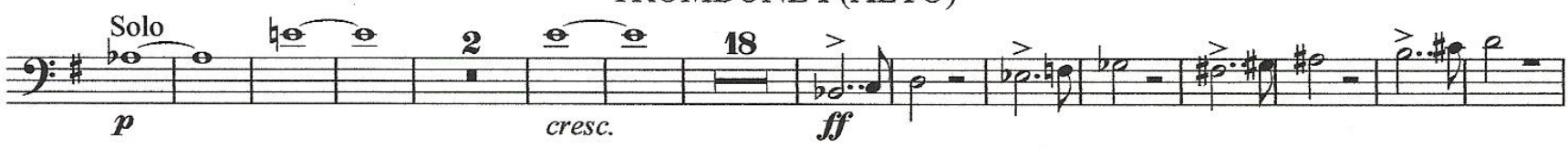

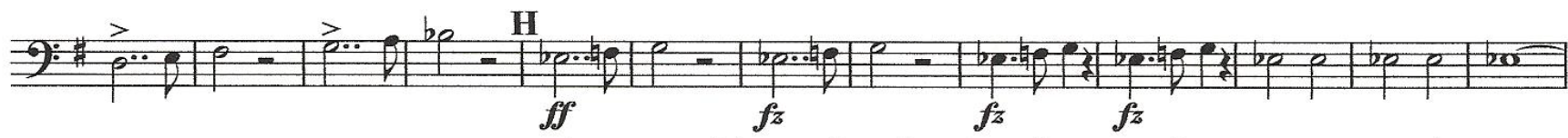
9:

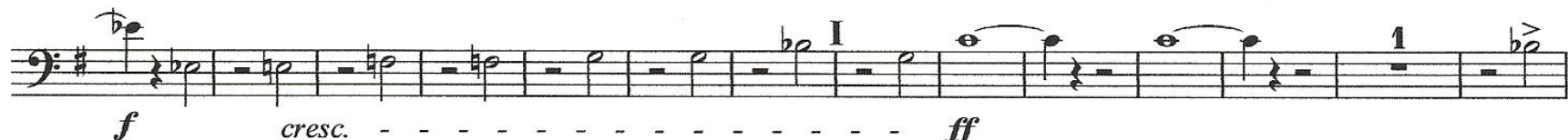



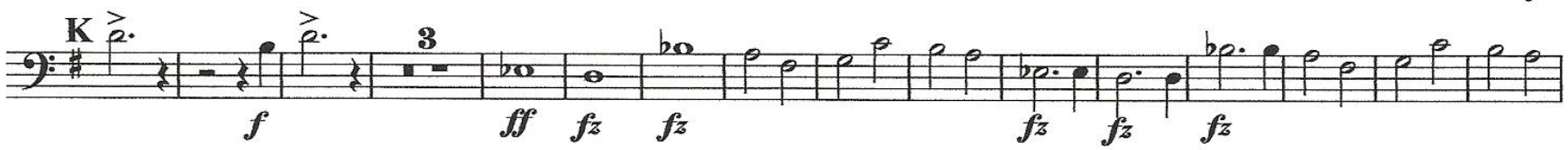

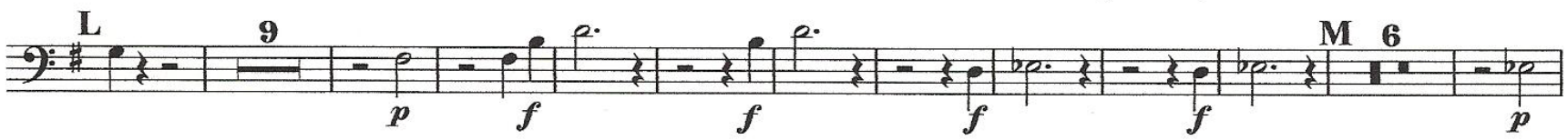



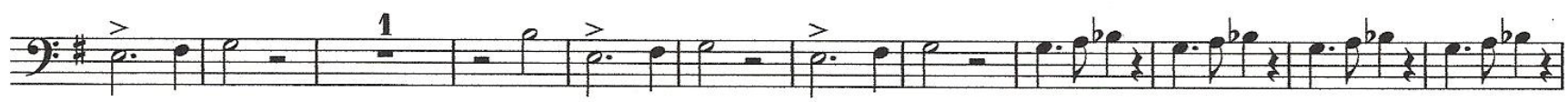

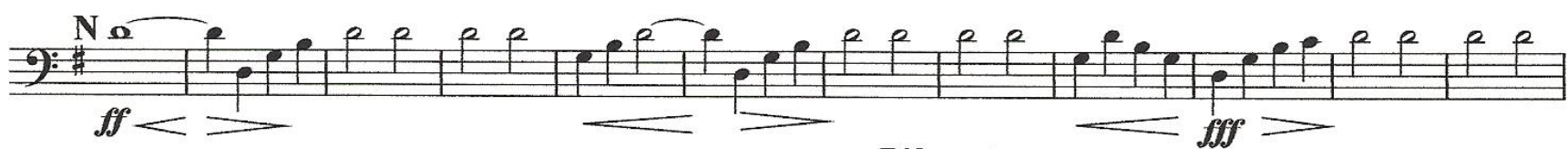

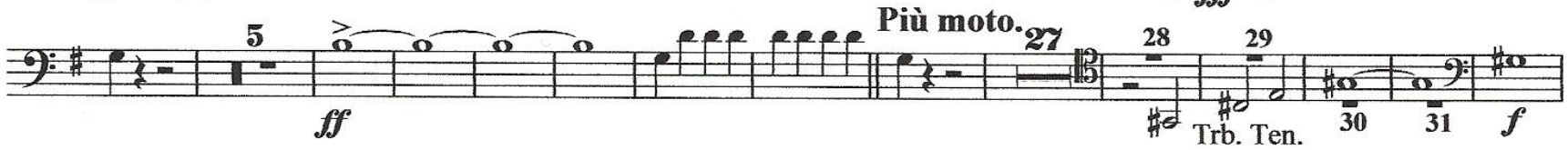

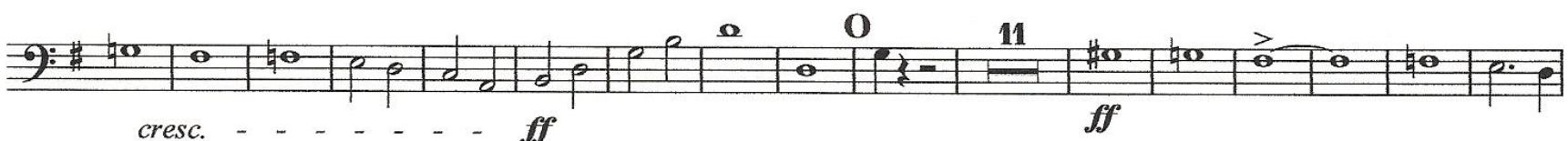




9:-10 ff

9:

Andante con moto.



$\frac{\text { 2: }}{f f}$

$\frac{90.00}{p}$

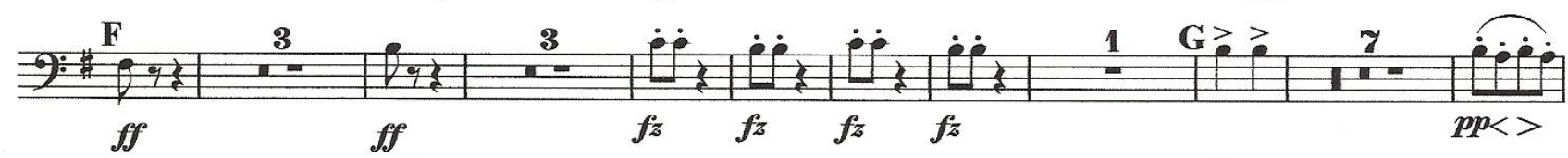

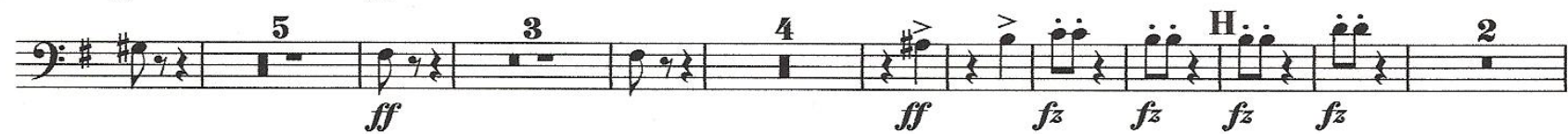

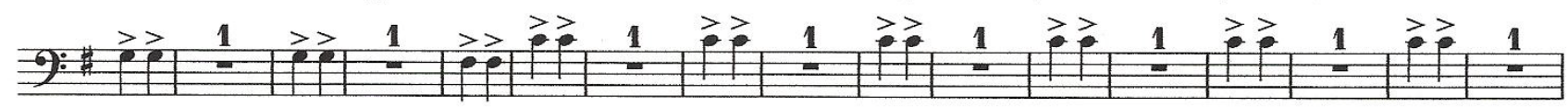

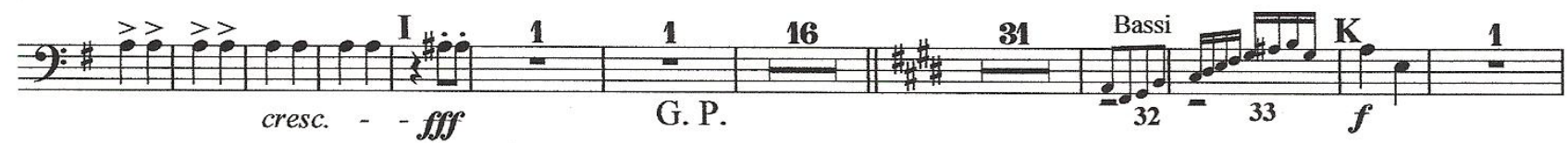
9): 1 $\underset{f f}{9:}$ 20: 
SCHERZO.

Allegro Vivace.



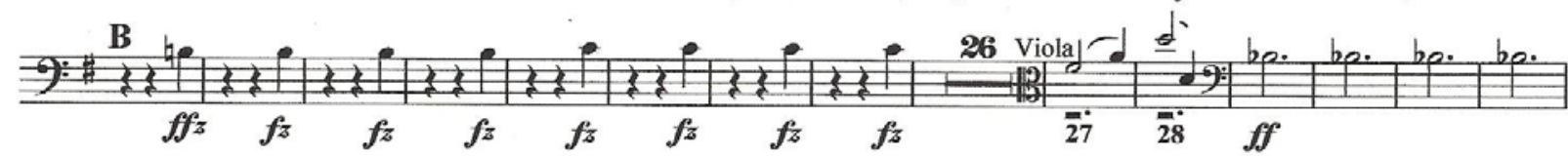

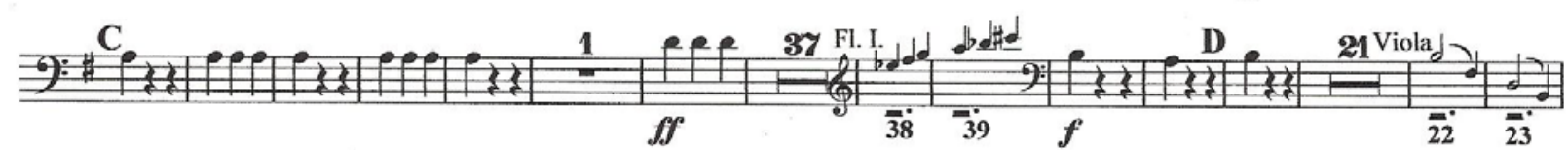
9:

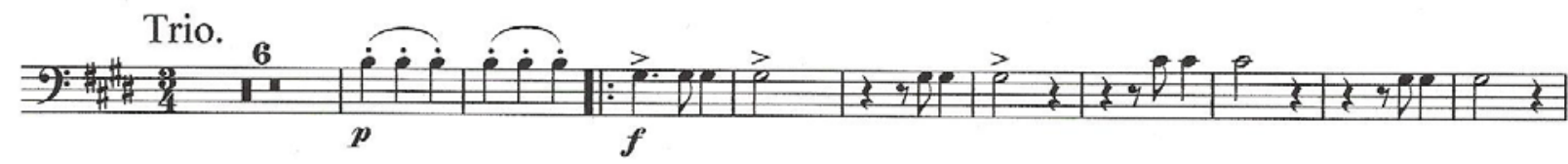

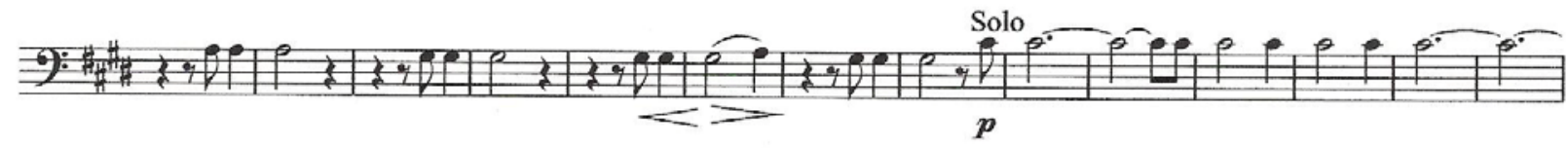
至

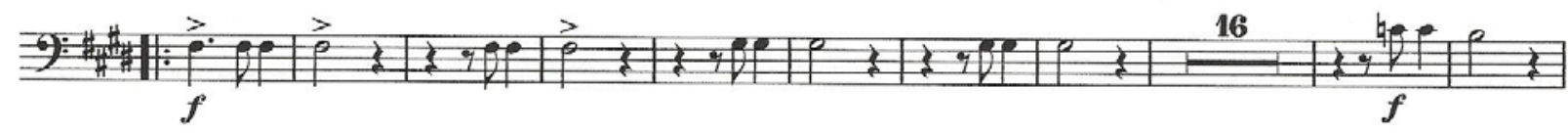
In 至

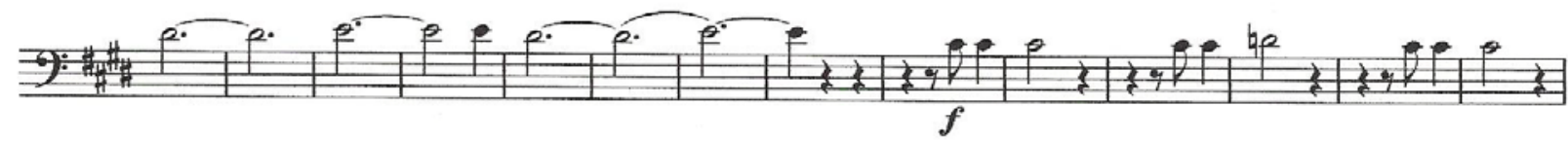
至 20 
Allegro vivace.

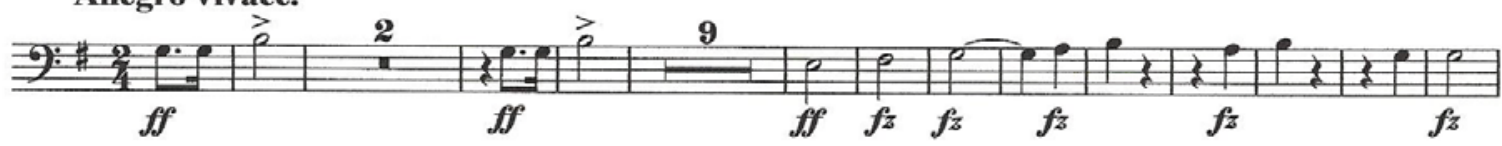

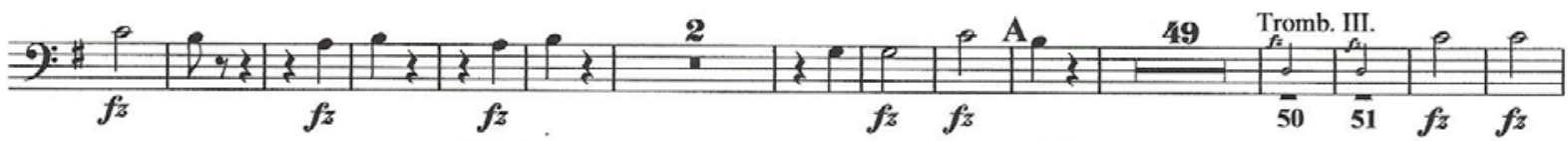

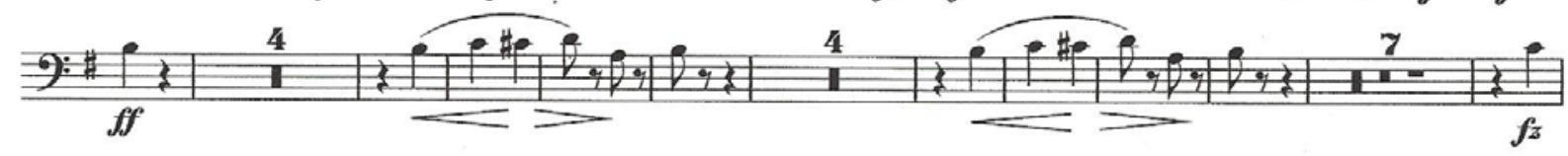
9:

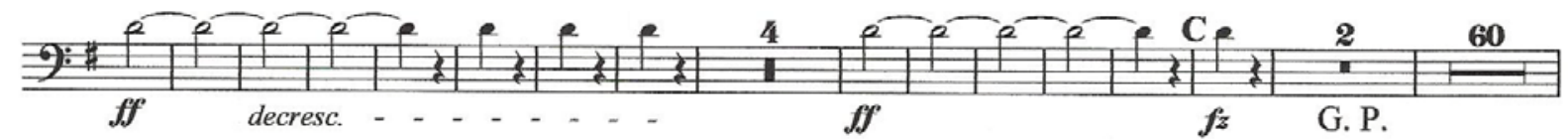

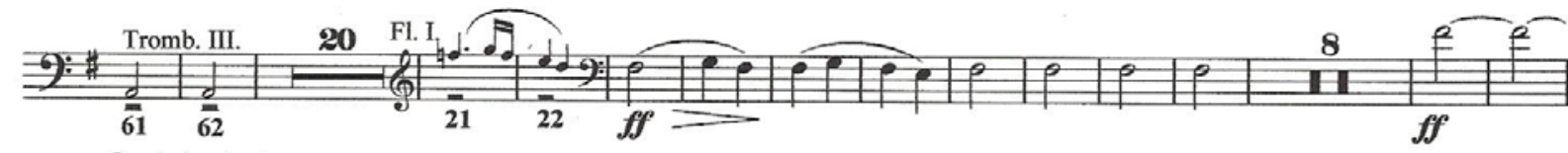



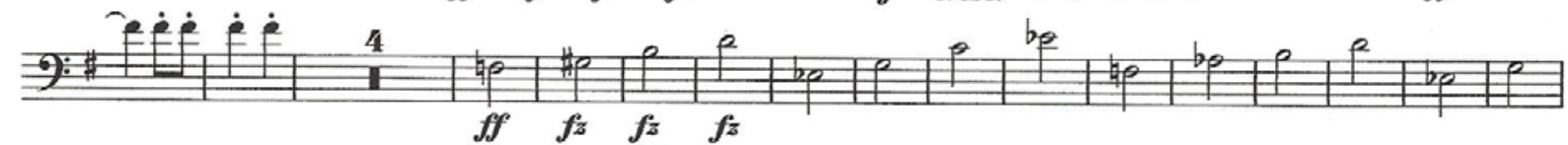

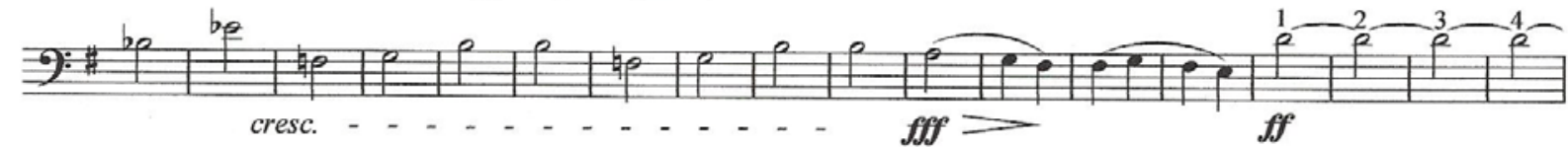

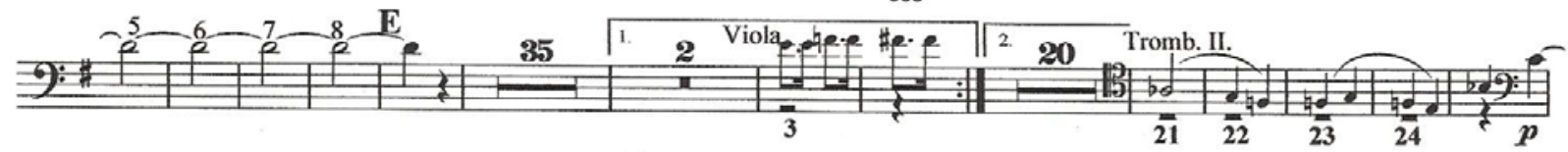
9:1) be be

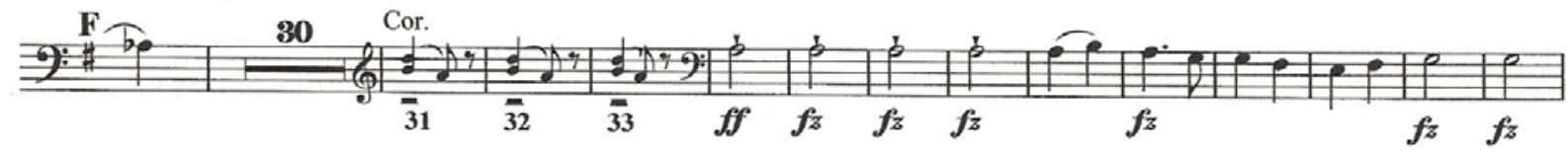

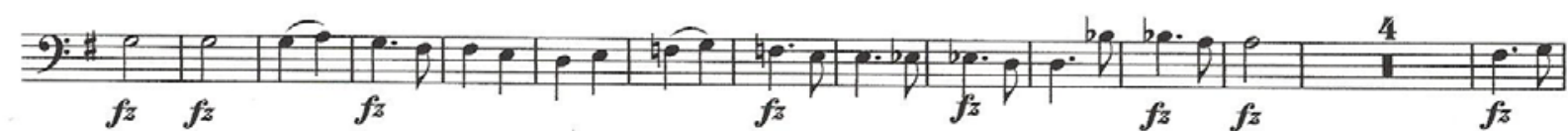

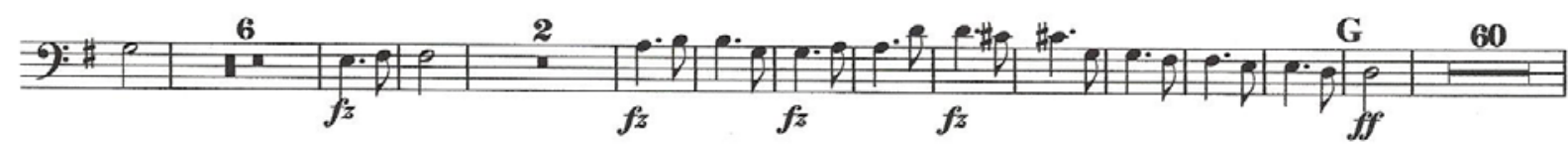


6

TROMBONE I (ALTO)

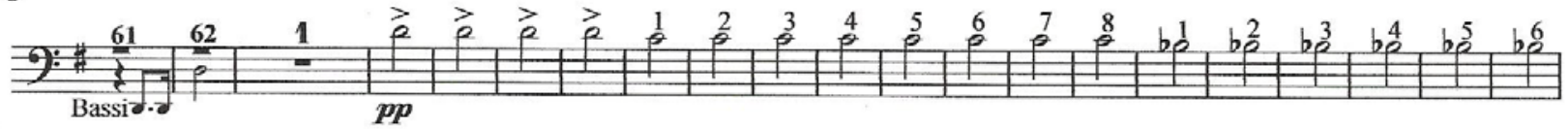

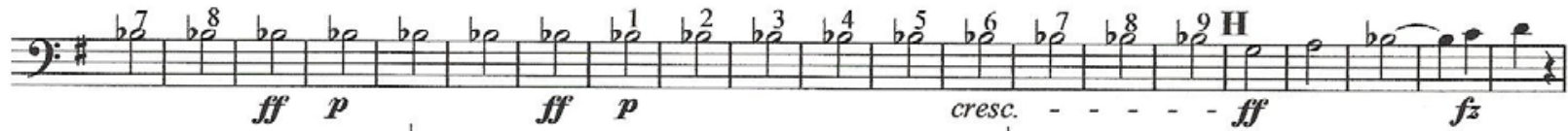

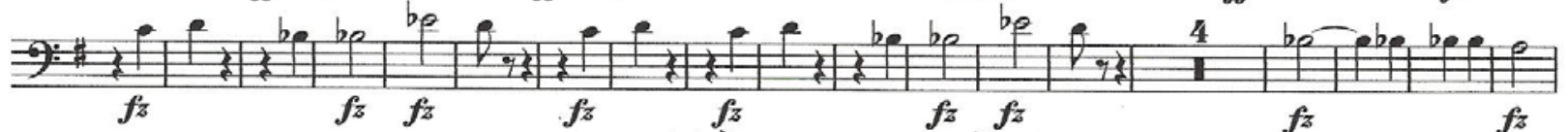

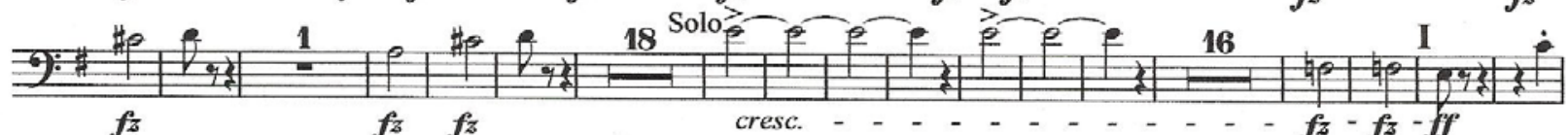

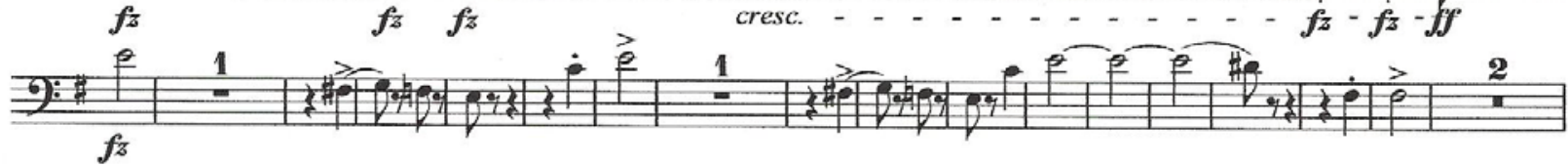

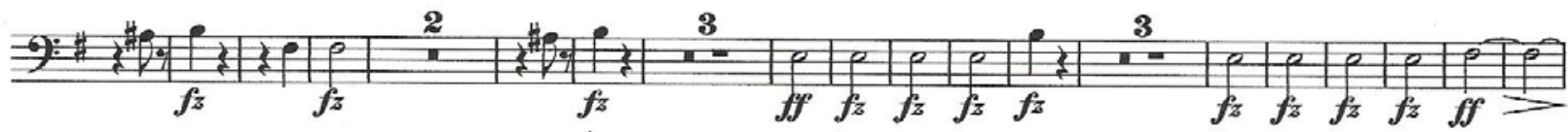

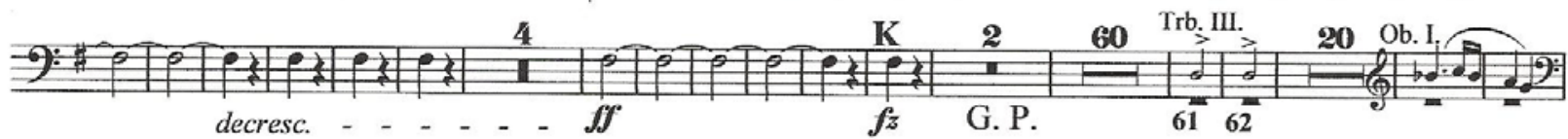

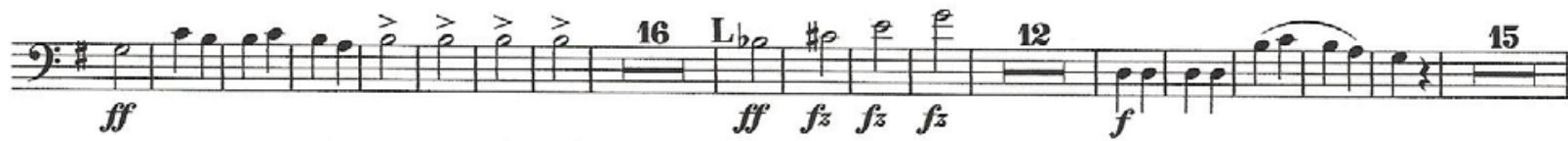

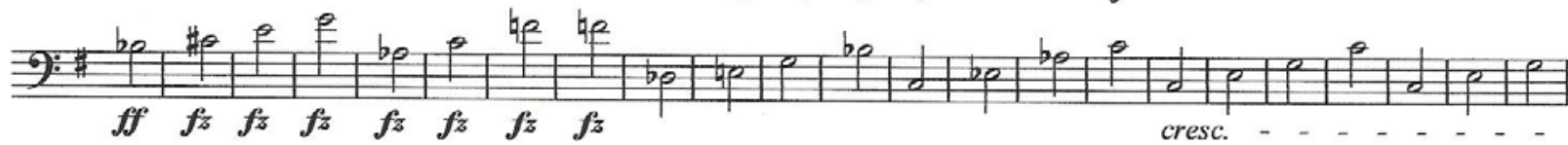



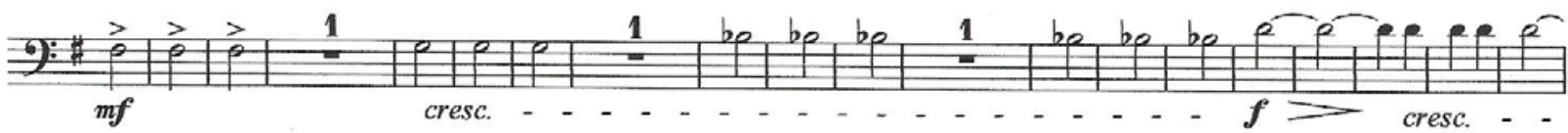

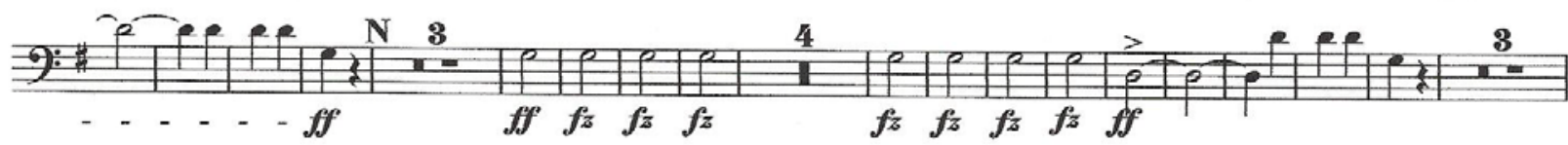

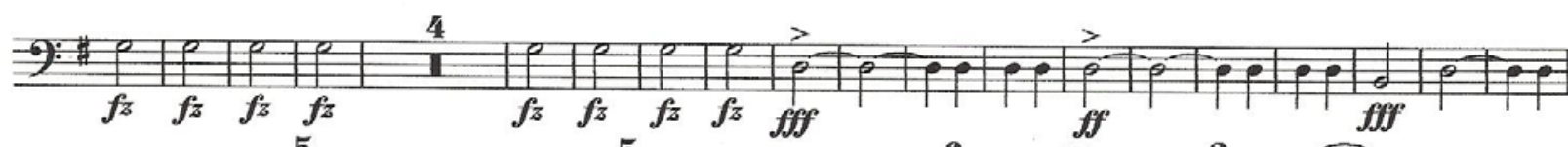
G):

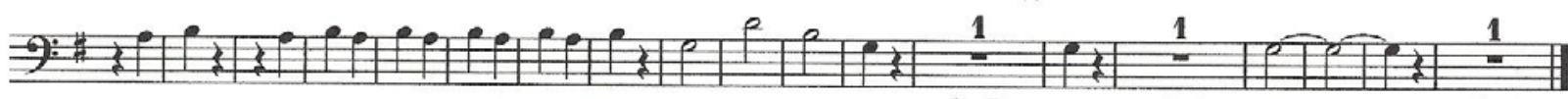
G. P.
G. P. $f^{\prime z}$
G. P. 


\section{Symphony No. 3}

Alto Trombone I, II, and III tacet

Robert Schumann, Op. 97 (transposed)

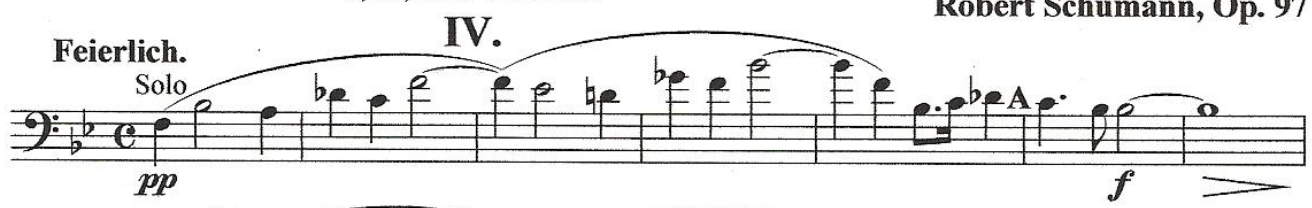

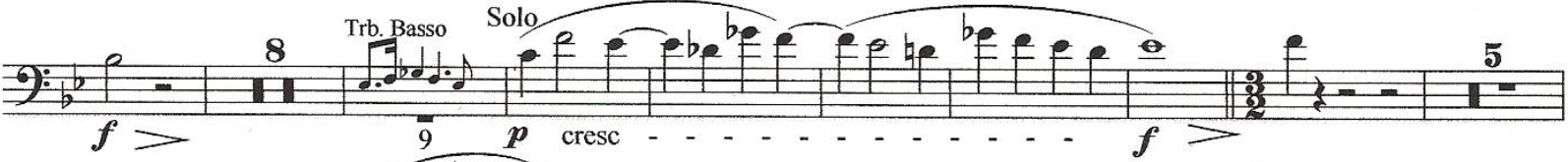
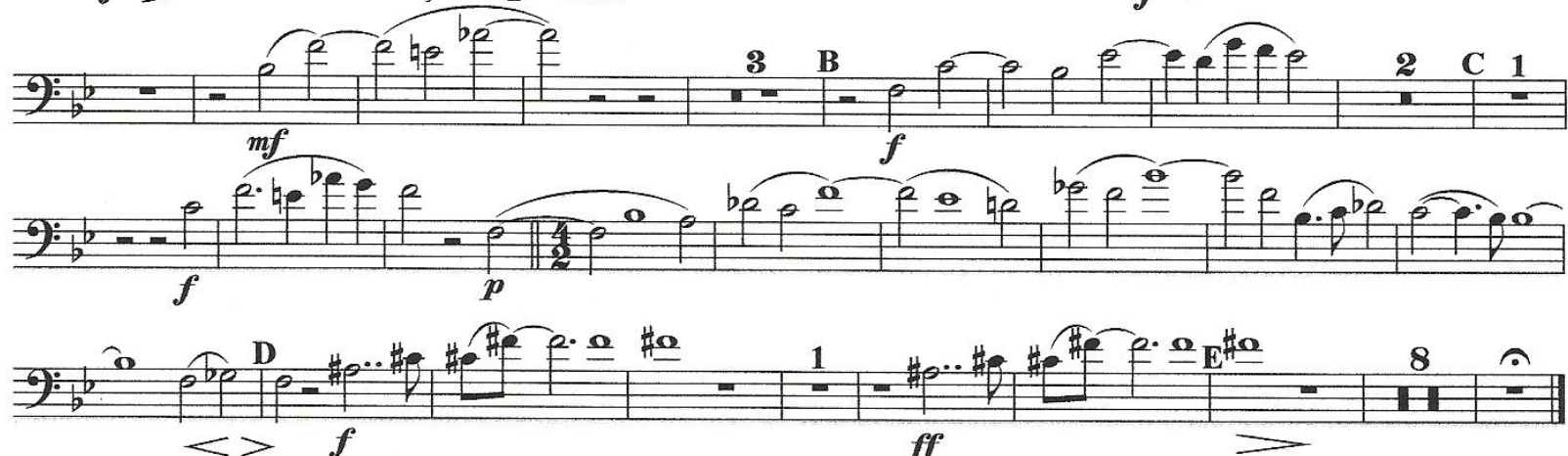

V.

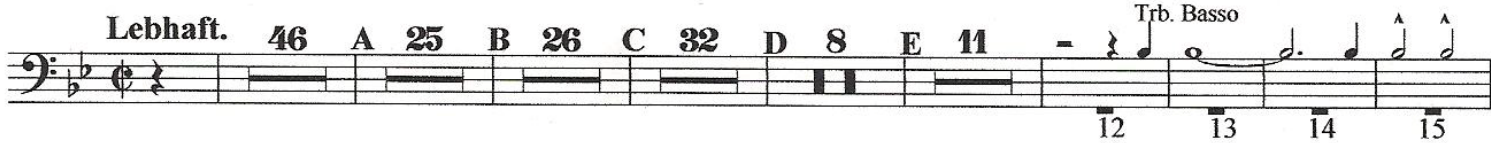

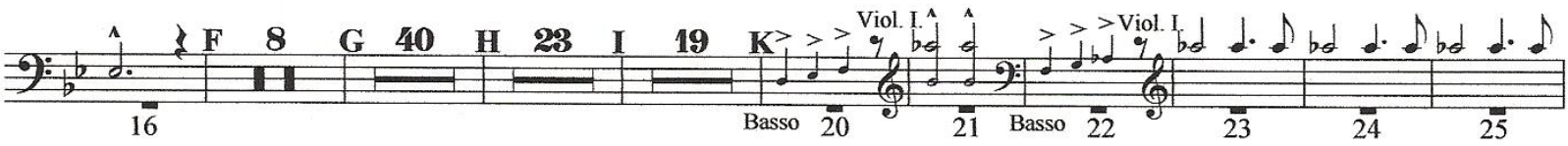

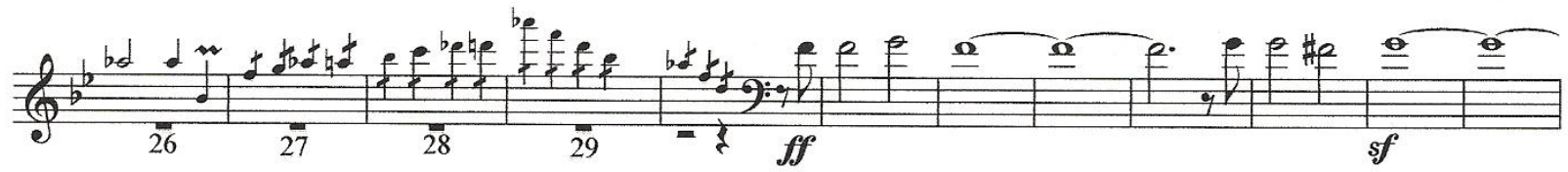



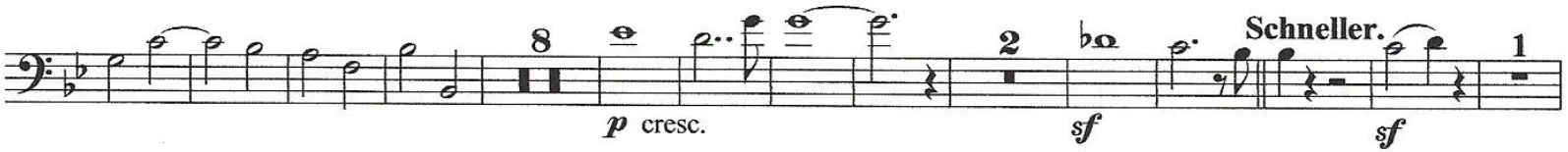

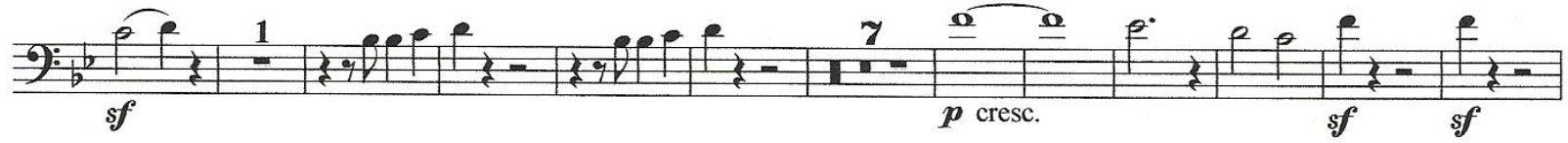






\section{BIBLIOGRAPHY}

Adler, Samuel. The Study of Orchestration, $2^{\text {nd }}$ edition. New York: W. W. Norton \& Company, Inc., 1989.

Anderson, Stephen C. "The Alto Trombone, Then and Now." The Instrumentalist 40 (November 1985): pp. 54-62.

Anderson, Stephen C. A Complete Method for Eb Alto Trombone, 2 vols. Modern Editions, 1984-1986.

Anderson, Stephen C. “Music for Alto Trombone.” ITA Journal 13 (April 1985): pp. 42-43.

Anderson, Stephen C. Personal communication, June 26, 2009.

Apel, Willi. The Notation of Polyphonic Music 900-1600. Cambridge, MA: The Mediæval Academy of America, 1961.

Appert, Donald. "The Alto Trombone: Its Uses, Problems and Solutions." ITA Journal 8 (March 1980): pp. 13-14.

Arnold, Denis. "Con Ogni Sorte di Stromenti: Some Practical Suggestions." Brass Quarterly 2 (March 1959): pp. 99-109.

Arnold, Denis. Giovanni Gabrieli, Oxford Studies of Composers, vol. 12. London: Oxford University Press, 1974.

Baines, Anthony. Brass Instruments: Their History and Development. New York: Charles Scribner's Sons, 1978. 
Baines, Anthony and Arnold Myers. "The Trombone, §1: Slide trombone." Grove Music Online, ed. Deane Root. Offered through Oxford Music Online, Oxford University Press, 2007-2010. Available at <http://www.oxfordmusiconline. com>, accessed October 23, 2009.

Baines, Anthony and Janet Page. “Transposing Instruments, §3: Brass.” Grove Music Online, ed. Deane Root. Offered through Oxford Music Online, Oxford University Press, 2007-2010. Available at <http://www.oxfordmusiconline. com>, accessed October 23, 2009.

Barbieri, Patrizio. “Chiavette." Grove Music Online, ed. Deane Root. Offered through Oxford Music Online, Oxford University Press, 2007-2010. Available at <http://www.oxfordmusiconline.com>, accessed November 14, 2009.

Barbour, J. Murray. Trumpets, Horns, and Music. East Lansing, MI: Michigan State University Press, 1964.

Barbour, J. Murray. "Unusual Brass Notation in the Eighteenth Century." Brass Quarterly 2 (June 1959): pp. 139-146.

Bate, Philip. The Trumpet and Trombone: An Outline of their History, Development and Construction. London: Ernest Benn Limited, 1966.

Hector Berlioz, Fantastic Symphony [1830]: An Authoritative Score, Historical Background, Analysis, Views and Comments, ed. Edward T. Cone. Norton Critical Scores. New York and London: W. W. Norton and Company, 1971.

Berlioz, Hector and Richard Strauss. A Treatise on Modern Instrumentation and Orchestration [1844], trans. Theodore Front. First published with Richard Strauss in 1904. Reprint, New York: Edwin F. Kalmus, 1948. 
Blatter, Alfred. Instrumentation/Orchestration, $2^{\text {nd }}$ edition. New York: Schirmer Books, 1985.

Blazhevich, Vladislav. School for Trombone in Clefs including the All New Alto Studies, $2^{\text {nd }}$ edition, ed. by Andrey Kharlamov and Michael Deryugin, annot. by Ward Stare. First published in 1939. Chicago and Moscow: East-West Music International, Inc., 2008.

Carse, Adam. The History of Orchestration. New York: Dover Publications, Inc., 1964.

Carse, Adam. Musical Wind Instruments: A History of the Wind Instruments Used in European Orchestras and Wind-Bands from the Later Middle Ages Up to the Present Time. First published in London: Macmillan and Co., 1939. Reprint, New York: Da Capo Press, 1965.

Chew, Geoffrey and Richard Rastall. "Notation, §III, 4: Mensural notation from 1500: (v) Clefs, staves, and leger lines." Grove Music Online, ed. Deane Root. Offered through Oxford Music Online, Oxford University Press, 2007-2010. Available at <http://www.oxfordmusiconline.com>, accessed July 23, 2009.

Chiarizzio, Kevin. "Jérome Naulais: 20 Etudes Variées sure la virtuosité, le style et le rhythme for alto trombone. Paris: Gérard Billaudot Éditeur, 1995. Grade 56." Review in ITA Journal 33/4 (October 2005): pp. 81-82.

Cloutier, Daniel. Ludwig Van Beethoven's Orchestration of the Trombone. DMA Research Project, West Virginia University, 2009.

Darmiento, Frank. Alto Trombone Etudes. Scottsdale, AZ: Sackbut Music, 2006.

Dart, Thurston. The Interpretation of Music. New York and Evanston: Harper \& Row Publishers, 1963. 
Del Mar, Norman. Anatomy of the Orchestra. Berkley: University of California Press, 1981.

Downey, Peter. “The Renaissance Slide Trumpet: Fact or Fiction?" Early Music 12 (February 1984): pp. 26-33.

Edwards, Brad. Introductory Studies in Tenor and Alto Clef for Trombone: "Before Blazhevich." Ithaca, NY: Ensemble Publications, 2002.

Elias, Joel. "Rediscovering the Alto Trombone." The Instrumentalist 49 (October 1994): p. 50.

Ervin, Tom. Personal communication, July 3, 2009.

Fink, Reginald. Introducing the Alto Cleffor Trombone. North Greece, NY: Accura Music, 1969.

Fink, Reginald. The Trombonist's Handbook: A Complete Guide to Playing and Teaching. Athens, OH: Accura Music, 1970.

Flandrin, Gaston. Méthode Complète de Trombone á Coulisse Ténor, 2 vols. First published in Paris: Adolph Dubois, 1910. Reprint, Paris: E. Gaudet, 1923.

Flandrin, Gaston. "Le Trombone." in Encyclopédia de la Musique et Dictionnaire du Conservatoire, Deuxième Partie: Technique-Esthétique-Pédagogie, ed. Albert Lavignac. Paris: Librarie Delagrave, 1925: pp. 1649-1659.

Flor, Gloria J. "The Alto Trombone as a Beginner's Instrument." Woodwind, Brass, and Percussion 22 (September 1983): p. 13. 
Forsyth, Cecil. Orchestration. First published in New York: Macmillan Co., 1914. Reprint, New York: Dover Publications, 1982.

Gabrieli, Giovanni. "Sacræ Symphoniæ [1597]" in Corpus Mensurabilis Musicæ, vol. 12 (10), ed. Richard Charteris. Neuhausen, Germany: American Institute of Musicology-Hänssler-Verlag, 1998.

Gasparovic, Jozef. Alto Trombone-Work with Instrument. Bratislava, Slovakia: Príloha, 2000.

Gevaert, François. Nouveau Traité D'Instrumentation. Paris and Brussels: Lemoine et Fils Éditeurs, 1885.

Gregory, Robin. The Trombone, The Instrument and its Music. New York and Washington: Praeger Publishers, 1973.

Guion, David. The Trombone: Its History and Music 1697-1811. New York: Gordon and Breach, 1988.

Hartman, Mark. The Use of the Alto Trombone in Symphonic and Operatic Orchestral Literature. DMA Research Paper, Arizona State University, 1985.

Harvey, Roger. BrassWorkBook for Alto Trombone. Essex, UK: BrassWorks, 1998.

Hiebert, Thomas. "The Horn in the Baroque and Classical Periods." in The Cambridge Companion to Brass Instruments, ed. Trevor Herbert and John Wallace. Cambridge, UK: Cambridge University Press, 1997: pp. 103-114.

Herbert, Trevor. "'Sackbut': the Early Trombone." in The Cambridge Companion to Brass Instruments, ed. Trevor Herbert and John Wallace. Cambridge, UK: Cambridge University Press, 1997: pp. 68-83. 
Herbert, Trevor. The Trombone. New Haven and London: Yale University Press, 2006.

Herbert, Trevor and John Wallace. "Aspects of Performance Practices: The Brass Band and its Influence on other Brass-Playing Styles." in The British Brass Band: A Musical and Social History, ed. Trevor Herbert. London: Oxford University Press, 2000: pp. 278-305.

Horwood, Wally. "Transposition-the logical approach." Crescendo International 10 (January 1972): pp. 39-40.

Jaeckle, Franklin. A Comprehensive Performance Project in Trombone Literature with an Essay consisting of a Method Book for the E-flat Alto Trombone. DMA Essay, University of Iowa, 1982.

Johansen, David. An Essay Consisting of an Examination of Alto Trombone Use in Metropolitan and Regional Symphony Orchestras in the United States and of Pedagogical Materials and Curricula Currently Available for that Instrument. DMA Essay, University of Iowa, 1993.

Kahila, Kauko. Advanced Studies (In Tenor and Alto Clefs) for Trombone. North Easton, MA: Robert King Music Company, 1948.

Karasick, Simon. "The Alto and Contrabass Trombone." Music Journal 26 (January 1968): pp. 30, 73.

Karkoschka, Erhard. Notation in New Music. New York: Praeger Publishers, 1972.

Kavanaugh, Lee Hill. "Babes in Slideland: Preschool Trombone students in Scandinavia." ITA Journal 24 (Fall 1996): pp. 38-45. 
Kehle, Robert. "Alto Trombone Homepage." Pittsburg State University, Department of Music [online], 2010. Available at <http://www.pittstate.edu/department/ music/kehle/alto-trombone.dot>, accessed January 23, 2010.

Kehle, Robert. Alto Trombone Literature: An Annotated Guide, $2^{\text {nd }}$ edition. Coventry, England: Warwick Music Limited, 2005.

Kennan, Kent and Donald Grantham. The Technique of Orchestration, $5^{\text {th }}$ edition. Upper Saddle River, NJ: Prentice Hall, 1997.

Kenton, Egon. Life and Works of Giovanni Gabrieli, Musicological Studies and Documents, ed. Armen Carapetyan, vol. 16. Middleton, WI: American Institute of Musicology, 1967.

Kharlamov, Andrey. Vladislav Blazhevich: A History of his Life, Career, and Compositions. DM Document, Northwestern University, 2005.

Kimball, Will. "Alto Trombone Timeline." Will Kimball, Trombone [online], 2010. Available at < http://www.kimballtrombone.com/alto-trombone/altotrombone-history-timeline/>, accessed January 23, 2010.

Kimball, Will. "Learning the Alto Trombone." Will Kimball, Trombone [online], 2010. Available at <http://www.kimballtrombone.com/alto-trombone/learningthe-alto-trombone/>, accessed January 23, 2010.

Kimball, Will. "The Rise and Fall...and Rise of the Alto Trombone." NACWPI JournalOfficial Publication of the National Association of College Wind and Percussion Instructors 48 (Spring 2000): pp. 23-28.

Kimball, Will and Joseph Hansen. "Alto Trombone Pedagogical Materials." ITA Journal 35 (January 2007): pp. 44-46. 
Koechlin, Charles. Traité de L'Orchestration, vol. 1. Paris: Éditions Max Eschig, 1954.

Lafosse, André. School of Sight Reading and Style for Tenor Trombone, Book E. New York: M. Baron Co., 1949.

Lafosse, André. Traité de Pédagogie du Trombone á Coulisse. Paris: Alphonse Leduc, 1955.

Lindberg, Christian. "Why a Bb Attachment on the Alto Trombone?" ITA Journal 19 (Summer 1991): p. 26.

Macdonald, Hugh. Berlioz's Orchestration Treatise: A Translation and Commentary. Cambridge: Cambridge University Press, 2002.

Mathie, David. The Alto Trombone: Twentieth-Century Performance Practices and Pedagogy in the United States. DMA Document, University of Georgia, 1993.

Mau, Gudrun. Altoposaunenschule: Übungen und Lieder um die ersten Tone. Kißlegg, Germany: Musikverlag Gudrun Mau, 2005.

Maxted, George. Twenty Studies for Tenor Trombone. London: Boosey and Hawkes Ltd., 1954.

Miller, Robert. School for Trombone, Book III. New York: Spratt Music Publishers, 1950.

Mitchell, Lawrence LaVern. A Comprehensive Performance Project in Trombone Literature With an Essay Consisting of Performance Editions of Selected Intermediate Level Solos Transcribed and Edited for E-Flat Alto Trombone and Piano. DMA Essay, University of Iowa, 1987. 
Merwin, Kedrik. "The Bordogni Vocalises by David Schwartz: A Review." Online Trombone Journal, 2010. Available at <http://www.trombone.org/articles/ library/viewarticles.asp?ArtID=197>, accessed March 1, 2010.

Mullen, Robert. 32 Etudes for Alto Trombone. Newton, Iowa: Tap Music Sales, 1984.

Myers, Arnold. "Instruments and Instrumentation of British Brass Bands." in The British Brass Band: A Musical and Social History, ed. Trevor Herbert. London: Oxford University Press, 2000: pp. 155-186.

Naulais, Jérôme. 20 Etudes variées Sur la Virtuosité: Le Style et le Rhythm. Contemporary Studies \#14, Trombone Alto. Paris: Gérard Billaudot Éditeur, 1988.

Nøkleby, Astrid. Rett På Musikken [On To The Music: An Introduction in English]. Norway: Warner/Chappell, 2000.

Nøkleby, Astrid. “Tots on Trombone.” ITA Journal 27 (Summer 1999): pp. 20-21.

Parow, Karsten. Initiation Complete au Trombone Alto, ed. Gerard Billaudot. Paris: Gerard Billaudot, 1982.

Piston, Walter. Orchestration. New York: W. W. Norton \& Company, Inc., 1955.

Praetorius, Michael. Syntagma Musicum II De Organographia: Parts I and II [1619], translated and ed. by David Z. Crookes. Oxford: Oxford University Press, 1986.

Prout, Ebenezer. Instrumentation. First published in London: Novello, Ewer and Co., 1879. Reprint, St. Clair Shores, MI: Scholarly Press, 1970.

Rastall, Richard. The Notation of Western Music. New York: St. Martin's Press, 1982. 
Read, Gardner. Music Notation: A Manual of Modern Practice, 2nd edition. Boston: Allyn and Bacon, Inc., 1969.

Read, Gardner. Source Book of Proposed Music Notation Reforms. New York; Westport, Connecticut; London: Greenwood Press, 1987.

Reese, Gustave. Music in the Renaissance. New York: W.W. Norton and Co., Inc., 1959.

Rohner, Traugott. "Introducing the F Alto Trombone." The Instrumentalist 18 (19491950): p. 18.

Saeki, Shigeki. “An Historical Perspective of the Alto Trombone." Brass Bulletin 115 (2001): p. 96-101.

Sauer, Ralph. Clef Studies for Trombone. Century City, CA: Wimbledon Music, 1977.

Sauer, Ralph. "The Alto Trombone in the Symphony Orchestra." ITA Journal 7 (July 1984): pp. 41-42

Schardinel, Ursel. Altoposaunenschule für Kinder. Seboldhausen, Germany: Musikschulbedarf \& Buchversand, 1998.

Schardinel, Ursel. Personal communication, June 6, 2009.

Schwartz, David. The Bordogni Vocalises, vol. 1: Solo part for Alto Trombone, transcribed from Marco Bordogni's 24 Nouvelles Vocalises à la Portée de Toutes les Voix [no date]. Belmont, MA: David A. Schwartz, 2007.

Seaton, Douglass. Ideas and Styles in the Western Musical Tradition. Mountain View, CA: Mayfield Publishing Company, 1991. 
Shifrin, Ken. "The Alto Trombone in the Orchestra 1800-2000." British Trombone Society [online], 2008. Extracted from PhD Thesis, Oxford University, 2000. Available at <http://www.britishtrombonesociety.org/resources/shifrin/ the-alto-trombone-in-the-orchestra-1800-2000.html>, accessed January 8, 2010.

Shifrin, Ken. The Orchestral Excerpt Series for the Orchestral "Doubler": The Professional's Handbook of Orchestral Excerpts, Alto Trombone. West Midlands, England: Virgo Music Publishers, 1986.

Shifrin, Ken. "Trombone Myth Busters No. 1: Dvorak Wrote for the Alto Trombone." ITA Journal 25 (Spring 1997): pp. 30-31.

Slocombe, Rob. "Fall and Rise of the Alto Trombone: 1830-2000." British Trombone Society [online], 2008. Available at <http://www.britishtrombonesociety. org/resources/current-articles/fall-and-rise-of-the-alto-trombone-18302000.html >, accessed January 8, 2010.

Slokar, Branimir. Methode Complete de Trombone Alto, vol. 1. Zumikon, Switzerland: Editions Marc Reift, 1983.

Sluchin, Benny. "Alto or Tenor Trombone: Open or Closed Case?." Historic Brass Society Journal 5 (1993): pp. 309-317.

Sluchin, Benny. Study Material for Alto Trombone, 4 vols. Warwick, England: Warwick Music, 2000-2003.

Sluchin, Benny and Raymond Lapie. "Slide Trombone Teaching and Method Books in France (1794-1960)." Historic Brass Society Journal 9 (1997): pp. 4-29. 
Smith, André. "Vladislav Mikhailovich Blazhevich (1886-1942): Some Recollections on the Semicentennial of His Death." ITA Journal 21 (Winter 1993): pp. 2227.

Stauffer, George. "The Modern Orchestra: A Creation of the Late Eighteenth Century." in The Orchestra: Origins and Transformations, ed. Joan Peyser. New York: Charles Scribner's Sons, 1986: pp. 37-68.

Stiller, Andrew. Handbook of Instrumentation. Berkeley, CA: University of California Press, 1985.

Strong, William and George Plitnik. Music, Speech, Audio, $2^{\text {nd }}$ edition. Provo, Utah: BYU Press, 2005.

Thompson, J. Mark. Personal communication, March 1, 2010.

Uber, David. First Studies in Alto Cleffor Trombone. Vancouver, British Columbia: Ward Music Ltd., 1986.

Virgiliano, Aurelio. Il dolcimelo [c. 1600], facsimile edition. Florence: Studio per Edizione Scelte, 1979.

Warner, Douglas G. Current Trends in Alto Trombone Pedagogy in the United States. DMA Document, University of Cincinnati, College-Conservatory of Music, 2005.

Weiner, Howard. “André Braun's Gamme et Méthode pour les Trombonnes: The Earliest Modern Trombone Method Rediscovered." Historic Brass Society Journal 5 (1993): pp. 288-308. 
Weiner, Howard. "Andreas Nemetz's Neueste Posaun-Schule: An Early Viennese Trombone Method." Historic Brass Society Journal 7 (1995): pp. 12-35.

Weiner, Howard. “François René Gebauer's 50 Leçons pour La Trombonne Basse, Alto, \& Tenor: The Earliest Book of Études for the Trombone." Historic Brass Society Journal 11 (1999): pp. 107-112.

Weiner, Howard. Personal communication, February 7, 2010.

Weiner, Howard. "When is an Alto Trombone an Alto Trombone? When is a Bass Trombone a Bass Trombone?-The Makeup of the Trombone Section in Eighteenth- and Early Nineteenth-Century Orchestras." Historic Brass Society Journal 17 (2005): pp. 37-79.

Wells, Wayne W. Music for the Trombone and Voice from the Hapsburg Empire: An Historical Overview with Tenor Trombone Transcriptions. DMA Dissertation, University of Maryland, 2005.

Whitener, Scott. A Complete Guide to Brass: Instruments and Technique, $3^{\text {rd }}$ edition. Belmont, CA: Thomson/Schirmer Books, 2007.

Williams, C. F. Abdy. The Story of Notation. First published by Walter Scott Publishing Company, 1903. Reprint, New York: Greenwood Press Publishers, 1969.

Winkler, Klaus. Schule für Altposaune: Für Instrumente in F- und Es- Stimmung. Munich, Germany: Bund Christlicher Posaunenchöre Deutschlands, 1980. 